\title{
Niacin for primary and secondary prevention of cardiovascular events (Review)
}

Schandelmaier S, Briel M, Saccilotto R, Olu KK, Arpagaus A, Hemkens LG, Nordmann AJ

Schandelmaier S, Briel M, Saccilotto R, Olu KK, Arpagaus A, Hemkens LG, Nordmann AJ.

Niacin for primary and secondary prevention of cardiovascular events.

Cochrane Database of Systematic Reviews 2017, Issue 6. Art. No.: CD009744.

DOI: 10.1002/14651858.CD009744.pub2.

www.cochranelibrary.com 
TABLE OF CONTENTS

HEADER 1

ABSTRACT

PLAIN LANGUAGE SUMMARY

SUMMARY OF FINDINGS

BACKGROUND

OBJECTIVES

METHODS

RESULTS

Figure 1.

Figure 2.

Figure 3.

Figure 4.

Figure 5.

DISCUSSION

Figure 6.

AUTHORS' CONCLUSIONS

ACKNOWLEDGEMENTS

REFERENCES

CHARACTERISTICS OF STUDIES

DATA AND ANALYSES

Analysis 1.1. Comparison 1 Niacin versus control, maximum follow-up, available case analysis, Outcome 1 Overall mortality. ..

Analysis 1.2. Comparison 1 Niacin versus control, maximum follow-up, available case analysis, Outcome 2 Overall mortality, sensitivity analysis with stratification by risk of bias trials only.

Analysis 1.3. Comparison 1 Niacin versus control, maximum follow-up, available case analysis, Outcome 3 Fatal myocardial infarction.

Analysis 1.4. Comparison 1 Niacin versus control, maximum follow-up, available case analysis, Outcome 4 Cardiovascular mortality.

Analysis 1.5. Comparison 1 Niacin versus control, maximum follow-up, available case analysis, Outcome 5 Non-cardiovascular mortality.

Analysis 1.6. Comparison 1 Niacin versus control, maximum follow-up, available case analysis, Outcome 6 Non-fatal myocardial infarction.

Analysis 1.7. Comparison 1 Niacin versus control, maximum follow-up, available case analysis, Outcome 7 Fatal or non-fatal myocardial infarction.

Analysis 1.8. Comparison 1 Niacin versus control, maximum follow-up, available case analysis, Outcome 8 Fatal and non-fatal stroke.

Analysis 1.9. Comparison 1 Niacin versus control, maximum follow-up, available case analysis, Outcome 9 Revascularisation procedures.

Analysis 1.10. Comparison 1 Niacin versus control, maximum follow-up, available case analysis, Outcome $10 \mathrm{Flushing.} \quad$......... Analysis 1.11. Comparison 1 Niacin versus control, maximum follow-up, available case analysis, Outcome 11 Pruritus. .......... Analysis 1.12. Comparison 1 Niacin versus control, maximum follow-up, available case analysis, Outcome 12 Rash. ............... Analysis 1.13. Comparison $1 \mathrm{Niacin}$ versus control, maximum follow-up, available case analysis, Outcome 13 Headache. ....... Analysis 1.14. Comparison 1 Niacin versus control, maximum follow-up, available case analysis, Outcome 14 Gastrointestinal symptoms.

Analysis 1.15. Comparison 1 Niacin versus control, maximum follow-up, available case analysis, Outcome 15 Discontinuation of treatment due to side effects.

Analysis 1.16. Comparison 1 Niacin versus control, maximum follow-up, available case analysis, Outcome 16 New onset diabetes).

ADDITIONAL TABLES

APPENDICES

CONTRIBUTIONS OF AUTHORS

DECLARATIONS OF INTEREST

SOURCES OF SUPPORT 
[Intervention Review]

\section{Niacin for primary and secondary prevention of cardiovascular events}

Stefan Schandelmaier ${ }^{1}$, Matthias Briel2 ${ }^{2}$, Ramon Saccilotto², Kelechi K Olu², Armon Arpagaus², Lars G Hemkens², Alain J Nordmann²

1Department of Health Research Methods, Evidence, and Impact, McMaster University, Hamilton, Canada. ${ }^{2}$ Basel Institute for Clinical Epidemiology and Biostatistics, Department of Clinical Research, University of Basel, Basel, Switzerland

Contact address: Matthias Briel, Basel Institute for Clinical Epidemiology and Biostatistics, Department of Clinical Research, University of Basel, Basel, Switzerland. matthias.briel@usb.ch.

Editorial group: Cochrane Heart Group.

Publication status and date: New, published in Issue 6, 2017.

Citation: Schandelmaier S, Briel M, Saccilotto R, Olu KK, Arpagaus A, Hemkens LG, Nordmann AJ. Niacin for primary and secondary prevention of cardiovascular events. Cochrane Database of Systematic Reviews 2017, Issue 6. Art. No.: CD009744. DOI: 10.1002/14651858.CD009744.pub2.

Copyright @ 2017 The Cochrane Collaboration. Published by John Wiley \& Sons, Ltd.

\section{A B S T R A C T}

\section{Background}

Nicotinic acid (niacin) is known to decrease LDL-cholesterol, and triglycerides, and increase HDL-cholesterol levels. The evidence of benefits with niacin monotherapy or add-on to statin-based therapy is controversial.

\section{Objectives}

To assess the effectiveness of niacin therapy versus placebo, administered as monotherapy or add-on to statin-based therapy in people with or at risk of cardiovascular disease (CVD) in terms of mortality, CVD events, and side effects.

\section{Search methods}

Two reviewers independently and in duplicate screened records and potentially eligible full texts identified through electronic searches of CENTRAL, MEDLINE, Embase, Web of Science, two trial registries, and reference lists of relevant articles (latest search in August 2016).

\section{Selection criteria}

We included all randomised controlled trials (RCTs) that either compared niacin monotherapy to placebo/usual care or niacin in combination with other component versus other component alone. We considered RCTs that administered niacin for at least six months, reported a clinical outcome, and included adults with or without established CVD.

\section{Data collection and analysis}

Two reviewers used pre-piloted forms to independently and in duplicate extract trials characteristics, risk of bias items, and outcomes data. Disagreements were resolved by consensus or third party arbitration. We conducted random-effects meta-analyses, sensitivity analyses based on risk of bias and different assumptions for missing data, and used meta-regression analyses to investigate potential relationships between treatment effects and duration of treatment, proportion of participants with established coronary heart disease and proportion of participants receiving background statin therapy. We used GRADE to assess the quality of evidence.

\section{Main results}

We included 23 RCTs that were published between 1968 and 2015 and included 39,195 participants in total. The mean age ranged from 33 to 71 years. The median duration of treatment was 11.5 months, and the median dose of niacin was $2 \mathrm{~g} /$ day. The proportion of participants with prior myocardial infarction ranged from $0 \%$ (4 trials) to $100 \%$ (2 trials, median proportion $48 \%$ ); the proportion of participants taking statin ranged from $0 \%$ (4 trials) to $100 \%$ (12 trials, median proportion 100\%). 
Using available cases, niacin did not reduce overall mortality (risk ratio (RR) 1.05, 95\% confidence interval (CI) 0.97 to 1.12 ; participants = 35,543 ; studies $=12 ;\left.\right|^{2}=0 \%$; high-quality evidence), cardiovascular mortality (RR 1.02, $95 \% \mathrm{Cl} 0.93$ to 1.12 ; participants $=32,966 ;$ studies $=5 ; I^{2}=0 \%$; moderate-quality evidence), non-cardiovascular mortality (RR 1.12, 95\% Cl 0.98 to 1.28; participants = 32,966; studies = 5; $\left.\right|^{2}$ $=0 \%$; high-quality evidence), the number of fatal or non-fatal myocardial infarctions (RR 0.93, 95\% Cl 0.87 to 1.00; participants = 34,829; studies $=9 ; 1^{2}=0 \%$; moderate-quality evidence), nor the number of fatal or non-fatal strokes (RR $0.95,95 \% \mathrm{Cl} 0.74$ to $1.22 ;$ participants $=33,661$; studies $=7 ; 1^{2}=42 \%$; low-quality evidence). Participants randomised to niacin were more likely to discontinue treatment due to side effects than participants randomised to control group (RR $2.17,95 \% \mathrm{Cl} 1.70$ to 2.77 ; participants $=33,539 ;$ studies $=17 ; \mathrm{I}^{2}=77 \%$; moderate-quality evidence). The results were robust to sensitivity analyses using different assumptions for missing data.

\section{Authors' conclusions}

Moderate- to high-quality evidence suggests that niacin does not reduce mortality, cardiovascular mortality, non-cardiovascular mortality, the number of fatal or non-fatal myocardial infarctions, nor the number of fatal or non-fatal strokes but is associated with side effects. Benefits from niacin therapy in the prevention of cardiovascular disease events are unlikely.

\section{PLAIN LANGUAGE SUMMARY}

\section{Niacin for people with or without established cardiovascular disease}

\section{Review question}

We reviewed the evidence about the effects of niacin for the prevention of death and cardiovascular disease.

\section{Background}

Heart attack and stroke are the most common causes of death, illness, disability and reduced quality of life in industrialised countries.

Niacin (nicotinic acid, vitamin B3) was considered a promising candidate to prevent cardiovascular disease because it is known to lower cholesterol in the blood, which is one of the main risk factors. Therefore, long-term therapy with niacin was assumed to reduce the risk of heart attack, and stroke. We assessed whether clinical studies could show a benefit of taking niacin.

\section{Study characteristics}

We found 23 studies including 39,195 participants that compared niacin to placebo. The evidence is current up to August 2016. The majority of included participants were on average 65 years old and had already experienced a myocardial infarction. The participants took niacin or placebo for a period of between six months and five years. Seventeen out of 23 studies were fully or partially funded by the drug manufacturer with a commercial interest in the results of the studies.

\section{Key results}

Niacin did not reduce the number of deaths, heart attack or stroke. Many people (18\%) had to stop taking niacin due to side effects. The results did not differ between participants who had or had not experienced a heart attack before taking niacin. The results did not differ between participants who were or were not taking a statin (another drug that prevents heart attack and stroke). The overall quality of evidence was moderate to high.

In summary, we found no evidence of benefits from niacin therapy. 


\begin{tabular}{|c|c|c|c|c|c|c|}
\hline \multicolumn{7}{|c|}{$\begin{array}{l}\text { S U M M A R Y O F F I N D I N G S } \\
\text { Summary of findings for the main comparison. Niacin for primary and secondary prevention of cardiovascular events }\end{array}$} \\
\hline \multicolumn{7}{|c|}{ Niacin for primary and secondary prevention of cardiovascular events } \\
\hline \multicolumn{7}{|c|}{$\begin{array}{l}\text { Patient or population: people with or at risk of cardiovascular disease } \\
\text { Setting: secondary care and tertiary care } \\
\text { Intervention: niacin monotherapy or add-on } \\
\text { Comparison: placebo or usual care }\end{array}$} \\
\hline \multirow[t]{2}{*}{ Outcomes } & \multicolumn{2}{|c|}{$\begin{array}{l}\text { Anticipated absolute effects }{ }^{\star}(95 \% \\
\text { Cl) }\end{array}$} & \multirow[t]{2}{*}{$\begin{array}{l}\text { Relative effect } \\
(95 \% \mathrm{CI})\end{array}$} & \multirow{2}{*}{$\begin{array}{l}\text { № of partici- } \\
\text { pants } \\
\text { (studies) }\end{array}$} & \multirow{2}{*}{$\begin{array}{l}\text { Quality of the } \\
\text { evidence } \\
\text { (GRADE) }\end{array}$} & \multirow[t]{2}{*}{ Comments } \\
\hline & $\begin{array}{l}\text { Risk with } \\
\text { placebo }\end{array}$ & Risk with niacin & & & & \\
\hline \multirow{2}{*}{$\begin{array}{l}\text { Overall mortality } \\
\text { (follow-up: } 0.5 \text { years to } 5 \\
\text { years) }\end{array}$} & \multicolumn{2}{|c|}{ Study population } & \multirow{2}{*}{$\begin{array}{l}\text { RR } 1.05 \\
(0.97 \text { to } 1.12)\end{array}$} & \multirow{2}{*}{$\begin{array}{l}35,543 \\
(12 \mathrm{RCTs})\end{array}$} & \multirow{2}{*}{$\begin{array}{l}\oplus \oplus \oplus \oplus \\
\text { High }\end{array}$} & \multirow{2}{*}{$\begin{array}{l}\text { High-quality evidence that niacin does not } \\
\text { reduce overall mortality ( } \mathrm{Cl} \text { excludes clini- } \\
\text { cally important benefit) }\end{array}$} \\
\hline & 86 per 1000 & $\begin{array}{l}90 \text { per } 1000 \\
(83 \text { to } 96)\end{array}$ & & & & \\
\hline \multirow{2}{*}{$\begin{array}{l}\text { Cardiovascular mortality } \\
\text { (follow-up: } 1 \text { year to } 5 \\
\text { years) }\end{array}$} & \multicolumn{2}{|c|}{ Study population } & \multirow{2}{*}{$\begin{array}{l}\text { RR } 1.02 \\
\text { (0.93 to } 1.12 \text { ) }\end{array}$} & \multirow{2}{*}{$\begin{array}{l}32,966 \\
\text { (5 RCTs) }\end{array}$} & \multirow{2}{*}{$\begin{array}{l}\oplus \oplus \oplus \odot \\
\text { Moderate } 1\end{array}$} & \multirow{2}{*}{$\begin{array}{l}\text { Moderate-quality evidence that niacin does } \\
\text { not reduce cardiovascular mortality }\end{array}$} \\
\hline & 63 per 1000 & $\begin{array}{l}64 \text { per } 1000 \\
\text { (58 to } 70)\end{array}$ & & & & \\
\hline \multirow{2}{*}{$\begin{array}{l}\text { Non-cardiovascular mor- } \\
\text { tality } \\
\text { (follow-up: } 1 \text { year to } 5 \\
\text { years) }\end{array}$} & \multicolumn{2}{|c|}{ Study population } & \multirow{2}{*}{$\begin{array}{l}\text { RR } 1.12 \\
(0.98 \text { to } 1.28)\end{array}$} & \multirow{2}{*}{$\begin{array}{l}32,966 \\
\text { (5 RCTs) }\end{array}$} & \multirow{2}{*}{$\begin{array}{l}\oplus \oplus \oplus \oplus \\
\text { High }\end{array}$} & \multirow{2}{*}{$\begin{array}{l}\text { High-quality evidence that niacin does not } \\
\text { reduce non-cardiovascular mortality (Cl ex- } \\
\text { cludes clinically important benefit) }\end{array}$} \\
\hline & 24 per 1000 & $\begin{array}{l}27 \text { per } 1000 \\
\text { (24 to } 31)\end{array}$ & & & & \\
\hline \multirow{2}{*}{$\begin{array}{l}\text { Fatal or non-fatal myocar- } \\
\text { dial infarction } \\
\text { (follow up: } 0.5 \text { years to } 5 \\
\text { years) }\end{array}$} & \multicolumn{2}{|c|}{ Study population } & \multirow{2}{*}{$\begin{array}{l}\text { RR } 0.93 \\
(0.87 \text { to } 1.00)\end{array}$} & \multirow{2}{*}{$\begin{array}{l}34,829 \\
\text { (9 RCTs) }\end{array}$} & \multirow{2}{*}{$\begin{array}{l}\oplus \oplus \oplus \ominus \\
\text { Moderate } 1\end{array}$} & \multirow{2}{*}{$\begin{array}{l}\text { Moderate-quality evidence that niacin does } \\
\text { not reduce the number of fatal and non-fa- } \\
\text { tal myocardial infarctions }\end{array}$} \\
\hline & 95 per 1000 & $\begin{array}{l}90 \text { per } 1000 \\
(83 \text { to } 95)\end{array}$ & & & & \\
\hline \multirow{2}{*}{$\begin{array}{l}\text { Fatal and non-fatal stroke } \\
\text { (follow-up: } 0.5 \text { years to } 5 \\
\text { years) }\end{array}$} & \multicolumn{2}{|c|}{ Study population } & \multirow{2}{*}{$\begin{array}{l}\text { RR } 0.95 \\
\text { (0.74 to } 1.22 \text { ) }\end{array}$} & \multirow{2}{*}{$\begin{array}{l}33,661 \\
(7 \mathrm{RCTs})\end{array}$} & \multirow{2}{*}{$\begin{array}{l}\oplus \oplus \oplus \ominus \\
\operatorname{Low}^{1,2}\end{array}$} & Low-quality evidence that niacin does not \\
\hline & 47 per 1000 & $\begin{array}{l}45 \text { per } 1000 \\
(35 \text { to } 59)\end{array}$ & & & & \\
\hline
\end{tabular}




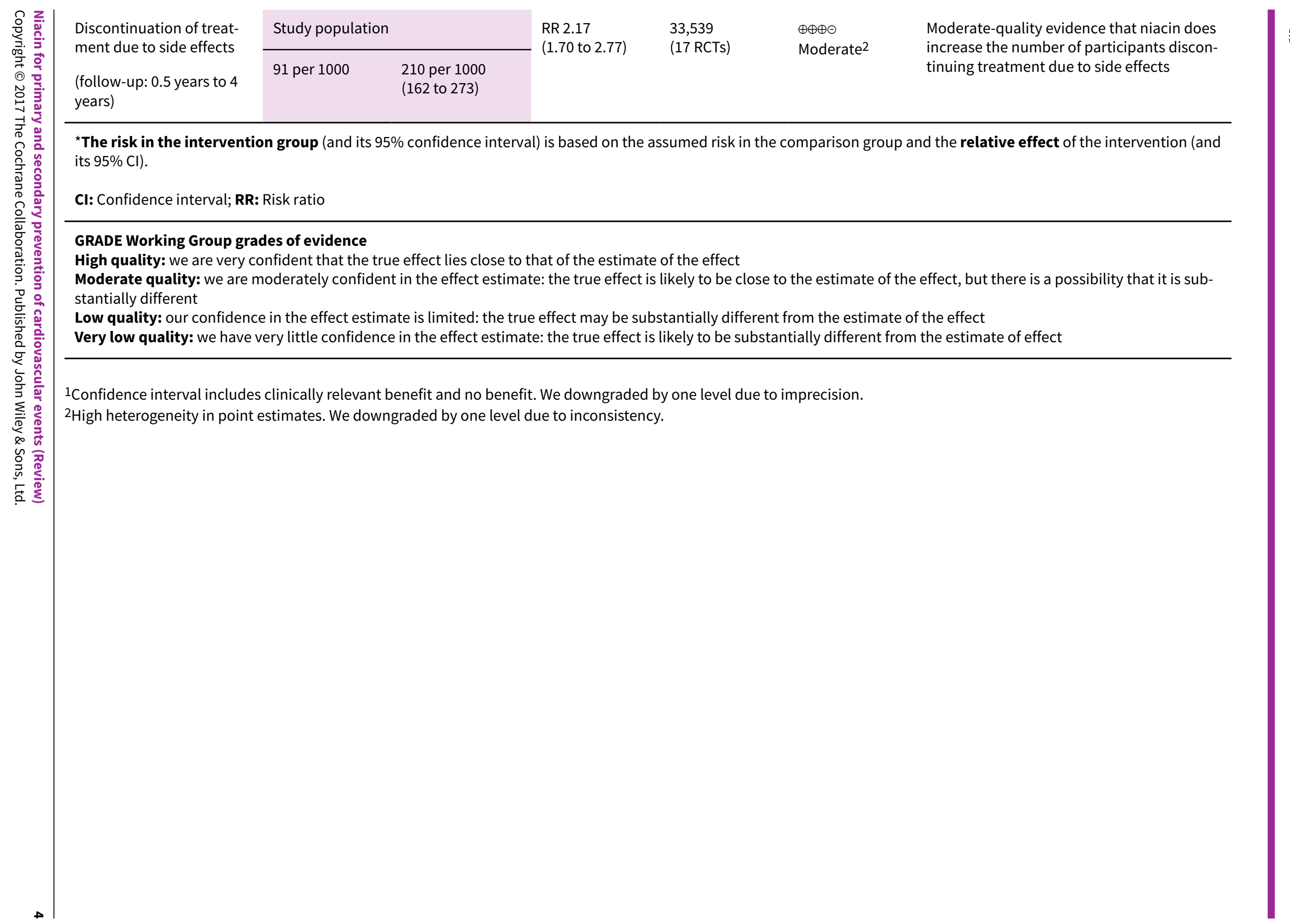




\section{B A C K G R O U N D}

\section{Description of the condition}

Cardiovascular disease (CVD) is the most common cause of death, illness, disability and reduced quality of life in industrialised countries (Thom 2006). Mortality data for 2011 show that CVD accounted for one of three deaths in the USA (approximately 800,000 ) (Mozaffarian 2015). One of the major risk factors for CVD is elevated low-density lipoprotein cholesterol (LDL-C). In individuals with elevated LDL-C, statins (HMG CoA reductase inhibitors) are considered to be the first choice of pharmacological therapy, since they reduce CVD events and total mortality independently of baseline LDL-C levels (4S 1994; Baigent 2005; Graham 2007; HCSBG 2002; Hooper 2001; Lestra 2005; Mills 2010). However, despite significant risk reduction with statin therapy, many cardiac events are not prevented. Moreover, some people are unable to tolerate or have contraindications to statin therapy. Therefore, further investigation of additional or alternative lipid-lowering drug therapies is needed (Cannon 2008).

\section{Description of the intervention}

Nicotinic acid (niacin, vitamin B3) is a candidate to lower the remaining risk as it is known to decrease LDL-C, triglycerides and lipoprotein (a). In addition, it is the most effective currently available drug to increase high-density lipoprotein cholesterol (HDL-C) levels by up to 35\% (Birjmohun 2005; McKenney 2004; Singh 2007). Common side effects of niacin therapy include skin flushing (up to $71 \%$ ), headache (8\%), pruritus (6\%) and gastrointestinal symptoms (10\%) (Ballantyne 2008a; Ballantyne 2008b; Insull 2009; Karas 2008; Zhao 2004). Skin flushing often leads to discontinuation of niacin treatment, although it is a tachyphylactic phenomenon, that is, once the body compensates, it is most likely that the frequency and intensity of such episodes will decrease within days or weeks and may even go away completely. Therefore, strategies to reduce flushing were developed, including modified release preparations, administration of aspirin, and formulation with laropiprant. Glucose intolerance with or without overt diabetes is another potential side effect of niacin therapy and may require adjustment of antihyperglycaemic therapy (Grundy 2002).

\section{How the intervention might work}

A meta-analysis published in 2006 and including 23 studies found that CVD event rates are reduced by nearly $1 \%$ for each $1 \%$ reduction in $\mathrm{LDL}-\mathrm{C}$ and by at least $1 \%$ for each $1 \%$ increase in $\mathrm{HDL}$ C, regardless of LDL-C reduction (Brown 2006). These findings imply a significant benefit of HDL-C-raising therapy independent of LDL$C$ reduction. However, a systematic review and meta-regression analysis including 108 studies found no additional effect of raised HDL-C levels on fatal or non-fatal myocardial infarction or overall mortality when the analysis was adjusted for changes in LDL-C levels (Briel 2009). A more recent meta-regression analysis also raised doubt as to the proposed relationship between HDL-C and risk of cardiac events (Hourcade-Potelleret 2015).

Decision analytic computer models have been used to estimate the economic value in terms of costs per life years gained for niacin therapy in addition to existing lipid-lowering therapy with statins. With incremental cost-effectiveness ratios (ICER) between EUR 10,000 and EUR 20,000, add-on niacin therapy was judged to be cost-effective (Michailov 2011; Roze 2007). However, these models rely on the assumption of an additional outcome benefit due to raised HDL-C levels, which is yet to be determined. Nevertheless, the cost of niacin treatment is generally considered to be low (Meyers 2003).

\section{Why it is important to do this review}

The evidence of CVD benefits with niacin therapy is controversial. Several randomised trials have investigated the efficacy and safety of niacin alone or in combination with other lipid-modifying drugs, focusing mostly on surrogate end points like changes in lipid profiles or carotid intima-media thickness as primary outcomes (e.g. Ballantyne 2008a; Canner 1986; JAMA 1975; Lee 2009; Maccubbin 2008; Moore 2007; Taylor 2004; Taylor 2009; Vaccari 2007). Several previous meta-analyses investigated the effects of lipid-modifying drugs and included niacin RCTs. However, these meta-analyses were either not based on systematic reviews (Goldberg 2004, Guyton 2009a, Bays 2012a, McKenney 2010, McKenney 2015) or they included niacin combination therapy (i.e. niacin plus another agent) or active control groups (e.g. niacin versus other lipid-modifying drugs) where it is impossible to discern any potentially incremental effects of niacin (Birjmohun 2005; Bruckert 2010; Charland 2010; Duggal 2010; Goldie 2015; Gould 2007; Keene 2014; Verdoia 2015). We identified only one previous systematic review and meta-analysis that addressed explicitly the incremental effect of niacin on patient-relevant outcomes: Ip 2015 assessed the effect of add-on lipid-modifying therapy on top of background statin treatment on major cardiovascular events. They included various comparisons but presented the subgroup of three RCTs that investigated the effect of niacin as add-on therapy (AIM-HIGH 2011; ARBITER-2 2004; HPS2-THRIVE 2014). None of the summary effects on clinical outcomes were significant. The risk ratio (RR) for all-cause mortality was 1.10 (95\% confidence interval $(\mathrm{Cl}) 1.00$ to $1.20, \mathrm{I}^{2}=0 \%$ ), the RR for major cardiovascular events was $1.03\left(95 \% \mathrm{Cl} 0.85\right.$ to $\left.1.25, \mathrm{l}^{2}=48 \%\right)$, the RR for death from coronary heart disease was $1.07\left(95 \% \mathrm{Cl} 0.94\right.$ to $1.21, \mathrm{I}^{2}$ $=0 \%)$, the RR for myocardial infarction was $1.00(95 \% \mathrm{Cl} 0.83$ to $\left.1.20,1^{2}=29 \%\right)$, and the RR for stroke was $1.52(\mathrm{Cl} 0.57$ to 4.06. $1^{2}=11 \%$ ) in favour of the placebo group. However, the meta-analysis was limited to high risk patients taking background statin therapy and failed to discuss methodological limitations of included trials. The 2013 American College of Cardiology/ American Heart Association guideline on the treatment of blood cholesterol to reduce atherosclerotic cardiovascular risk in adults recommends considering re-emphasising adherence to lifestyle changes and to statin therapy before adding a non-statin drug (ACC/AHA guideline 2013). The expert panel could not find any data supporting the routine use of non-statin drugs combined with statin therapy to reduce cardiovascular events. In addition, no randomised controlled trials (RCTs) evaluating the effect of non-statin drugs on cardiovascular outcomes in statin-intolerant individuals were found.

\section{O B JECT IVES}

To assess the effectiveness of niacin therapy versus placebo administered as monotherapy or add-on to statin-based therapy in people with or at risk of cardiovascular (CVD) disease in terms of mortality, CDV events, and side effects. 


\section{METHODS}

\section{Criteria for considering studies for this review}

\section{Types of studies}

We included RCTs (published and unpublished) that documented an outcome of interest and had a treatment time (and thus followup) of at least six months.

\section{Types of participants}

Adults 18 years or older with or without established CVD disease.

\section{Types of interventions}

- Combination therapy including niacin plus other lipidmodifying drug(s) versus other lipid-modifying drug(s) alone for at least six months

- Niacin monotherapy versus placebo or usual care for at least six months

\section{Types of outcome measures}

\section{Primary outcomes}

- Overall mortality

\section{Secondary outcomes}

- Fatal myocardial infarction (including sudden death)

- Cardiovascular mortality (any death from cardiac or vascular cause)

- Non-cardiovascular mortality

- Non-fatal myocardial infarction

- Fatal or non-fatal myocardial infarction

- Fatal or non-fatal stroke

- Revascularisation procedures (bypass grafts, angioplasty)

- Patient-perceived quality of life (only measured using validated scales)

- Side effects, that is, skin flushing, pruritus, rash, headache, gastrointestinal symptoms, new onset of diabetes

- Discontinuation of treatment due to side effects

- Information on costs

\section{Search methods for identification of studies}

\section{Electronic searches}

We searched the following databases on 23 August 2016: Cochrane Central Register of Controlled Trials (CENTRAL, 2016, Issue 7) in the Cochrane Library, 'Epub Ahead of Print, In-Process \& Other Non-Indexed Citations, MEDLINE Daily and MEDLINE' (Ovid, 1946 to 23 August 2016), 'Embase Classic and Embase' (Ovid, 1947 to 2016 August 22), and Web of Science (Thomson Reuters, 1970 to 23 August 2016).

When searching MEDLINE and Embase we used the Cochrane sensitivity-maximising filter for RCTs (Lefebvre 2011) and an adaptation of it for Web of Science. The search strategies used can be found in Appendix 1. No date or language restrictions were imposed.

\section{Searching other resources}

We further screened reference lists of included studies, published editorials, and previous systematic reviews or meta-analysis reviews on the topic (Bays 2012a; Birjmohun 2005; Bruckert 2010; Charland 2010; Duggal 2010; Goldberg 2004; Gould 2007; Guyton 2009a; Hourcade-Potelleret 2015; Ip 2015; Keene 2014; McKenney 2010; McKenney 2015; Robinson 2009a; Singh 2007; Verdoia 2015).

In addition, we searched clinical trials registries in August 2016, (ClinicalTrials.gov and www.isrctn.com) for additional eligible studies and additional publications of included RCTs. We searched registries using synonyms for niacin ("niacin", "nicotinic", "vitamin B").

\section{Data collection and analysis}

\section{Selection of studies}

Investigators, working in teams of two (SS, AN), independently reviewed potentially eligible titles and abstracts. If either reviewer believed the study to be eligible, we obtained the full report. After obtaining full reports of the candidate studies (either in full peer-reviewed publication or press article) the two reviewers independently assessed eligibility from full-text papers. Discrepancies were resolved by reviewers' consensus or, if needed, third party arbitration.

\section{Data extraction and management}

Two reviewers (SS and AN) used pre-piloted forms to independently extract all relevant data on baseline characteristics of trials, participant populations, and outcomes. Any disagreements between reviewers were resolved by consensus.

\section{Assessment of risk of bias in included studies}

Working in teams of two, we independently assessed the quality of each included trial with respect to random sequence generation, concealment of treatment allocation, blinding of participants, caregivers, or assessors of clinical outcomes, completeness of follow-up (Jüni 1999), and selective reporting of outcomes (Higgins 2011a). The results are presented as risk of bias tables as outlined in the Cochrane Handbook for Systematic Reviews of Interventions (Higgins 2011a). Possible disagreement was resolved by consensus or third party arbitration if needed. We explored the influence of risk of bias on the primary outcome in a sensitivity analysis excluding RCTs with high or unclear risk of bias.

\section{Measures of treatment effect}

Ratio of risk for harmful events (risk ratio) and accompanying 95\% confidence intervals.

\section{Assessment of reporting biases}

We checked for outcome reporting bias by comparing reported outcomes to outcomes mentioned in corresponding trial protocols (provided they were published prospectively) or trial registry records (provided the trial was registered prospectively). We investigated the presence of publication bias by means of funnel plots (Egger 1997; Sterne 2001).

\section{Data synthesis}

We used random-effects model meta-analyses to calculate a weighted average of risk ratios across studies for all outcomes. 
We did not assume that all studies measure the same underlying true effect (that is, fixed-effect across studies) since we included primary and secondary prevention studies, and studies with and without background statin treatment. If a study reported more than one eligible comparison, we pooled the intervention arms and the control arms of the eligible comparisons. Whenever possible, we analysed participants as randomised irrespective of adherence to treatment. However, some studies excluded protocol violators from the follow-up or reported analysis. In that case, we also excluded them from our primary analysis, which was based on available cases. We considered available case analysis as our primary analysis because the underlying assumption is that missing data occurred at random. The commonly reported approach of using all randomised participants as a denominator for risks implicitly assumes no event for missing data which is less realistic than missing at random. We conducted all analyses using Review Manager 5 (RevMan 5) (RevMan 2014) and Stata 13 (stata.com).

In our analyses we made the following assumptions:

- If the denominator for available cases was not explicitly reported, we calculated the denominator by subtracting lost to follow-up from all randomised participants. For outcomes for which lost to follow-up was not reported, we assumed the available case denominator as reported or calculated for other outcomes. If the denominator differed by outcomes, we used the smallest.

- If a binary outcome was reported, both as a component of a composite endpoint (first occurrence) and as an independent outcome, we preferred the independent outcome in order to prevent bias due to competing risks.

- If myocardial infarction was not explicitly defined as fatal or nonfatal, we counted the events as 'fatal or non-fatal myocardial infarction' only. We used the same strategy for undefined stroke.

- If a specific side effect was reported both as 'discontinuation of treatment due to side effect' and 'experience of side effect', we preferred the latter in order to avoid assessment bias.

- If a specific side effect was only reported in combination with another side effect but not as an individual component (e.g. 'flushing or pruritus') we used the combined outcome in the meta-analysis of the individual component that occurred more frequently in other studies that reported both components. For example, if a study reported the outcome 'flushing or pruritus' we used 'flushing' in the meta-analysis because flushing occurred more frequently in other studies that reported both components separately.

- If several subcategories of an outcome (e.g. 'diarrhoea' as subcategory of 'gastrointestinal side effects') were reported but were not mutually exclusive, we assumed the outcome with the most events to represent the superordinate category. For instance, in a study that reported the outcomes 'diarrhoea' and 'vomiting', and 'diarrhoea' had more events than 'vomiting', we considered 'diarrhoea' to represent 'gastrointestinal side effects'.

- If a study reported that a participant was withdrawn from the study, but did not explicitly state whether the participant was withdrawn from the intervention (non-adherent) or from the follow-up (missing outcome data), we assumed withdrawal from follow-up.

\section{Subgroup analysis and investigation of heterogeneity}

We tested for heterogeneity with Cochrane's Q-test (Deeks 2011; Higgins 2002) and used $I^{2}$ (Higgins 2003) to measure inconsistency of treatment effects across primary and secondary outcomes. We conducted inverse variance-weighted metaregression analysis (Thompson 1999) to investigate any association between the outcomes and duration of niacin therapy, proportion of participants with established coronary heart disease, and proportion of participants receiving background statin therapy.

\section{Sensitivity analysis}

We conducted sensitivity analyses for all outcomes by assuming three different relationships between outcomes of missing and observed participants (Higgins 2008; command "metamiss" in Stata, Table 1 (stata.com)). Therefore, we specified the informative missingness odds ratio (IMOR = odds of event in missing data/ odds of event in observed data) and specified a distribution of the assumed relationship of the standard deviation $(\log I M O R=$ 0.5 ) to account for the uncertainty of this assumption. For the first sensitivity analysis, we assumed missingness at random (IMOR 1.0 in each arm) that results in similar point estimates for the individual trials but may change the summary estimate by downweighting studies with high proportions of missing data. In the second sensitivity analysis, we assumed a lower IMOR of 0.5 in the niacin arms and a higher IMOR of 2.0 in the control arms, thereby shifting the estimate in favour of niacin treatment. In a third sensitivity analysis, we assumed an IMOR of 2.0 in the intervention arms and an IMOR of 0.5 in the niacin arms thereby shifting the estimate in favour of the control treatment. We did draw forest plots given the minimal differences and large number of sensitivity analyses. For the primary outcome, we also conducted a sensitivity analysis restricting the analysis to trials with low risk of bias.

\section{'Summary of findings' table}

We created a 'Summary of findings' table using the following outcomes: overall mortality, cardiovascular mortality, noncardiovascular mortality, fatal or non-fatal myocardial infarction, fatal or non-fatal stroke, and discontinuation of treatment due to side effects. We used the five GRADE considerations (risk of bias, inconsistency, imprecision, indirectness and publication bias) to assess the quality of a body of evidence. We used methods and recommendations described in Section 8.5 (Higgins 2011a) and Chapter 12 (Schünemann 2011) of the Cochrane Handbook for Systematic Reviews of Interventions using GRADEpro GDT 2014 software. We used footnotes to justify all decisions to downgrade the quality of evidence.

\section{RES U L T S}

\section{Description of studies}

\section{Results of the search}

The search yielded 5631 unique records. We screened the full texts of 382 potentially eligible articles and finally included 23 RCTs (reported in 75 references) in our analysis (Figure 1; Characteristics of included studies). We excluded 307 articles including 65 RCTs involving niacin treatment that did not fulfil our eligibility criteria (Excluded studies). 
Figure 1. Study flow diagram

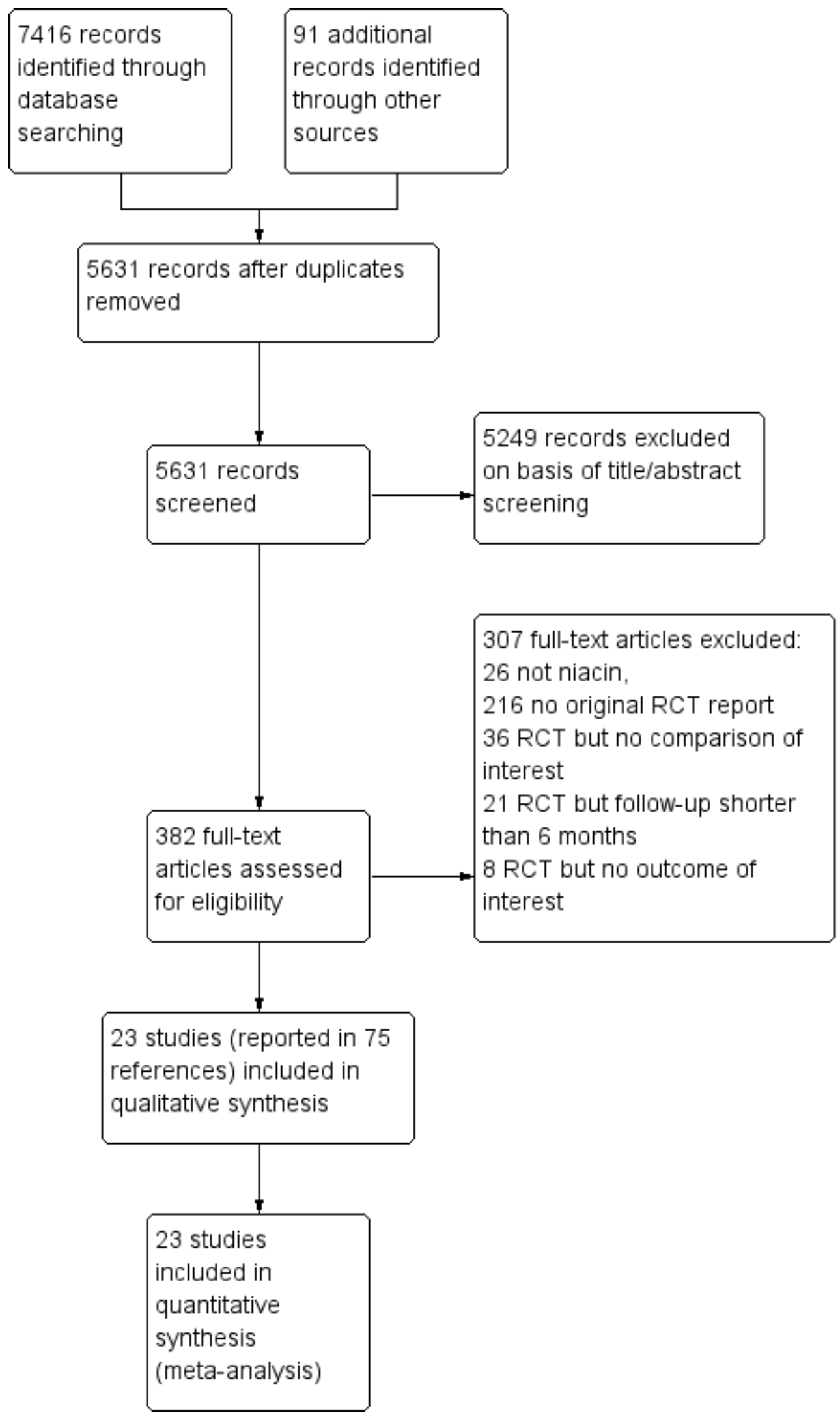




\section{Included studies}

\section{Methodology}

We included 23 RCTs that were published between 1968 and 2015. In total, we included 39,195 participants. The median duration of treatment was 11.5 months. Of the 23 RCTs, there was one prospectively published protocol (Heart positive 2011) and five retrospectively published protocols (after end of recruitment) (ADMIT 2000; AIM-HIGH 2011; CDP 1975; HPS2-THRIVE 2014; Hunninghake 2003); 12 (52\%) RCTs were registered in a clinical trials registry (all ClinicalTrials.gov). Pharmaceutical companies were mentioned as the only funding source in ten RCTs (ADMIT 2000; Capuzzi 2003; Carotid IMT 2008; Goldberg 2000; Guyton 2008; HPS2-THRIVE 2014; Hunninghake 2003; Lee 2009; Maccubbin 2008; MacLean 2011) and provided partial funding in another seven RCTs (ARBITER-2 2004; Harikrishnan 2008; Lee 2011; Linke 2009; Nash 2011; NIA Plaque 2013; Schoch 1968); four RCTs were explicitly not industry funded (AIM-HIGH 2011; ALPINE-SVG 2015; CDP 1975; Heart positive 2011) and funding was not disclosed in two RCTs (PAST 1995; Sang 2009).

\section{Populations}

Mean age ranged from 33 to 71 years across individual trials. Most trials included more men than women, two trials included as many women as men and only one trial (MacLean 2011) included more women than men. In two RCTs, all participants had experienced a prior myocardial infarction (CDP 1975; Schoch 1968) (secondary prevention trials). Four trials explicitly excluded people with prior myocardial infarction (Capuzzi 2003; Heart positive 2011; Linke 2009; Nash 2011) (primary prevention trials). In the remaining trials (mixed prevention trials), the proportion of individuals with prior myocardial infarction was in the range of $9 \%$ to $89 \%$ (ADMIT 2000; AIM-HIGH 2011; ALPINE-SVG 2015; ARBITER-2 2004; Guyton 2008; Harikrishnan 2008; HPS2-THRIVE 2014; Lee 2009; Lee 2011; NIA Plaque 2013; PAST 1995; Sang 2009) or was not reported in four trials (Carotid IMT 2008; Goldberg 2000; Hunninghake 2003; MacLean 2011).

Of the 23 included RCT populations, 16 (70\%) received therapy with statin (ADMIT 2000; AIM-HIGH 2011; ALPINE-SVG 2015; ARBITER-2 2004; Capuzzi 2003; Carotid IMT 2008; Guyton 2008; Harikrishnan 2008; HPS2-THRIVE 2014; Hunninghake 2003; Lee 2009; Lee 2011; Maccubbin 2008; MacLean 2011; NIA Plaque 2013; Sang 2009). The proportions of individuals receiving statin therapy ranged from $67 \%$ to $100 \%$. Statin therapy was part of the randomised interventions in eight RCTs, part of inclusion criteria in three RCTs, and part of allowed background therapy in five RCTs. The proportion of individuals receiving statins was $0 \%$ in four RCTs and not reported in three RCTs.

Most trials recruited participants in North America (ADMIT 2000; AIM-HIGH 2011; ARBITER-2 2004; Capuzzi 2003; CDP 1975; Goldberg 2000; Guyton 2008; Heart positive 2011; Hunninghake 2003; Nash 2011; NIA Plaque 2013; Schoch 1968), followed by Europe (Lee 2009; Linke 2009; PAST 1995), Asia (Harikrishnan 2008; Lee 2011; Sang 2009), or recruited world-wide (Carotid IMT 2008; HPS2-THRIVE 2014; Maccubbin 2008; MacLean 2011). Most studies did not report on the healthcare setting; four included participants in tertiary care (ALPINE-SVG 2015; ARBITER-2 2004; Capuzzi 2003; Harikrishnan 2008), one in secondary care (NIA Plaque 2013), and three from mixed healthcare settings (ADMIT 2000; Heart positive 2011; HPS2THRIVE 2014).

\section{Interventions}

The included trials administered a median dose of niacin of $2 \mathrm{~g} /$ day (range $0.5 \mathrm{~g} /$ day to $4.0 \mathrm{~g} /$ day) and the duration of treatment ranged between six months and six years. Nineteen trials applied one or more methods to reduce skin flushing due to niacin intake: Ten trials used an extended-release formula (ALPINE-SVG 2015; Capuzzi 2003; Goldberg 2000; HPS2-THRIVE 2014; Linke 2009; Maccubbin 2008; MacLean 2011; Nash 2011; NIA Plaque 2013; Sang 2009), four trials combined niacin with laropiprant (Carotid IMT 2008; HPS2-THRIVE 2014; Maccubbin 2008; MacLean 2011), ten trials gave aspirin prior to intake of niacin (AIM-HIGH 2011; ARBITER-2 2004; Goldberg 2000; Harikrishnan 2008; Hunninghake 2003; Lee 2009; Linke 2009; Maccubbin 2008; MacLean 2011; Nash 2011) and nine trials recommended intake at bedtime to reduce flushing, some together with a snack (AIM-HIGH 2011; ARBITER-2 2004; Capuzzi 2003; Goldberg 2000; Guyton 2008; Hunninghake 2003; Lee 2009; Maccubbin 2008; Nash 2011). Four trials (ADMIT 2000; ALPINE-SVG 2015; AIM-HIGH 2011; Heart positive 2011) applied a placebo that contained a minimal dose of niacin, enough to trigger skin flushes but with no effect on lipid levels, in order to prevent unblinding due to flushing.

Table 2 provides an overview of the change in lipid parameters associated with niacin therapy for each included RCT. Niacin increased the concentration of HDL-C and decreased the concentration of triglycerides in all studies that reported these data. Niacin decreased the concentrations of LDL-C and total cholesterol in most studies.

\section{Comparisons}

Of the 23 RCTs, 14 had a placebo for niacin in the control group (ADMIT 2000; ALPINE-SVG 2015; AIM-HIGH 2011; ARBITER-2 2004; Carotid IMT 2008; CDP 1975; Goldberg 2000; HPS2-THRIVE 2014; Lee 2009; Maccubbin 2008; MacLean 2011; Nash 2011; NIA Plaque 2013; Schoch 1968). The remaining nine RCTs administered standard treatment without a specific placebo for niacin (Capuzzi 2003; Guyton 2008; Harikrishnan 2008; Heart positive 2011; Hunninghake 2003; Lee 2011; Linke 2009; PAST 1995; Sang 2009).

\section{Outcomes}

Ten trials specified a serum lipid parameter as their primary outcome (Capuzzi 2003; Goldberg 2000; Guyton 2008; Heart positive 2011; Hunninghake 2003; Maccubbin 2008; MacLean 2011; Nash 2011; Sang 2009; Schoch 1968), seven trials an angiographic outcome (AIM-HIGH 2011; ALPINE-SVG 2015; Carotid IMT 2008; Lee 2009; Lee 2011; NIA Plaque 2013; PAST 1995), two trials a composite of cardiovascular events (AIM-HIGH 2011; HPS2-THRIVE 2014), one trial feasibility (ADMIT 2000), and another trial overall mortality (CDP 1975). Two trials did not specify a primary outcome (Harikrishnan 2008; Linke 2009).

Of the 23 RCTs, 12 (52\%) reported the outcome overall mortality, the primary outcome of the present systematic review. Of these, five specified overall mortality explicitly as an outcome (AIMHIGH 2011; ARBITER-2 2004; CDP 1975; HPS2-THRIVE 2014; Schoch 1968) while the remaining seven studies reported overall mortality under safety/adverse events (Goldberg 2000; Hunninghake 2003; Maccubbin 2008; MacLean 2011; NIA Plaque 2013; PAST 1995; Sang 2009). 
None of the included studies reported information about quality of life or costs.

\section{Excluded studies}

Overall, we excluded 65 RCT reports that involved niacin treatment but did not report a comparison of interest (36 RCT reports), had a follow-up shorter than six months (21 RCT reports), or reported no ocutome of interest (8 RCT reports) (see Characteristics of excluded studies).

\section{Risk of bias in included studies}

Figure 2 and Figure 2 provide an overview of the risk of bias in individual studies. 
Figure 2. Risk of bias summary: review authors' judgements about each risk of bias item for each included study

\begin{tabular}{|c|c|c|c|c|c|c|c|}
\hline & 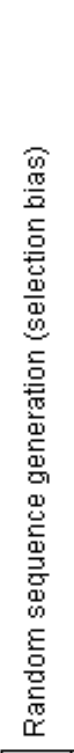 & 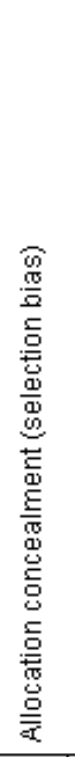 & 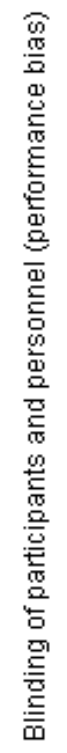 & 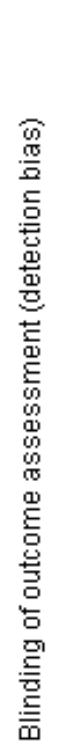 & 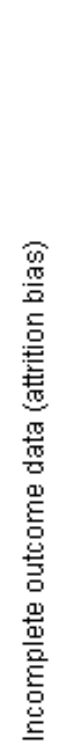 & 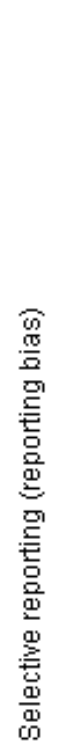 & 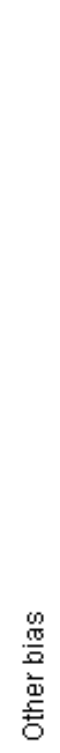 \\
\hline ADMIT 2000 & 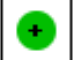 & $?$ & $\odot$ & $?$ & $\odot$ & $?$ & + \\
\hline AIM-HIGH 2011 & + & + & + & + & + & $\odot$ & + \\
\hline ALPINE-SVG 2015 & $?$ & $?$ & 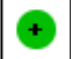 & + & + & $\odot$ & + \\
\hline ARBITER-2 2004 & 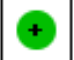 & + & 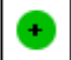 & $\oplus$ & $\odot$ & $?$ & + \\
\hline Capuzzi 2003 & $?$ & $?$ & - & $\odot$ & + & $?$ & + \\
\hline Carotid IMT 2008 & $?$ & $?$ & + & $?$ & 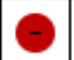 & $?$ & + \\
\hline $\operatorname{CDP} 1975$ & $?$ & $?$ & + & $?$ & + & $?$ & + \\
\hline Goldberg 2000 & $?$ & $?$ & 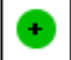 & $?$ & $\odot$ & $?$ & + \\
\hline Guyton 2008 & + & + & + & + & - & $?$ & + \\
\hline Harikrishnan 2008 & 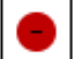 & $\odot$ & - & $\odot$ & $\odot$ & $?$ & $\odot$ \\
\hline Heart positive 2011 & $\odot$ & $\odot$ & $\odot$ & $?$ & $\odot$ & $?$ & + \\
\hline HPS2-THRIVE 2014 & 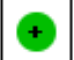 & $\odot$ & $\odot$ & 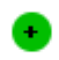 & $\odot$ & $\odot$ & + \\
\hline Hunninghake 2003 & $?$ & $?$ & 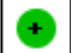 & $?$ & $?$ & $?$ & + \\
\hline Lee 2009 & $\odot$ & $?$ & $\odot$ & $?$ & $\odot$ & $?$ & $\odot$ \\
\hline Lee 2011 & $\odot$ & $?$ & $\theta$ & $\odot$ & 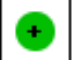 & $?$ & + \\
\hline Linke 2009 & $?$ & $?$ & - & $\odot$ & + & $?$ & + \\
\hline Maccubbin 2008 & + & + & + & $?$ & $O$ & $?$ & + \\
\hline MacLean 2011 & $?$ & + & 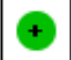 & $?$ & $\odot$ & $?$ & + \\
\hline Nash 2011 & + & + & $\odot$ & $\odot$ & + & $?$ & + \\
\hline NIA Plaque 2013 & + & $?$ & + & $?$ & $O$ & $\Theta$ & + \\
\hline
\end{tabular}


Figure 2. (Continued)

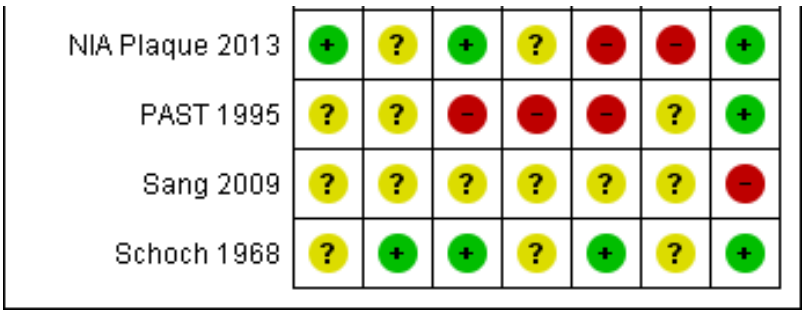

\section{Allocation}

Eleven trials reported a method to generate the random sequence (low risk of bias), 11 trials did not report the method of random sequence generation (unclear risk of bias), and one trial used quasi randomisation (high risk of bias) (Figure 2).

Eight trials reported an adequate method to conceal allocation (low risk of bias), 13 trials reported no method (unclear risk of bias), and two trials did clearly not conceal allocation (high risk of bias) (Figure 2)..

\section{Blinding}

Sixteen trials were reported as double-blind (low risk of performance bias), five as open-label and one as single-blind (high risk of performance bias), and the blinding status of participants and study personnel remained unclear in one trial (unclear risk of performance bias) (Figure 2).

Outcome assessment was blinded in five trials (low risk of detection bias), not mentioned in 12 trials (unclear risk of detection bias), and unblinded in six trials (high risk of detection bias) (Figure 2).

\section{Incomplete outcome data}

We judged the risk of attrition bias as high in 11 trials (proportion of missing data $>10 \%$, or ratio events/missing $<1$ ), unclear in two studies, and low in the remaining 10 studies (Figure 2). The median proportion of missing data in the 12 trials that reported overall mortality was $25 \%$ in the intervention arms and $19 \%$ in the control arm (Table 3). None of the included trials mentioned a sensitivity analysis for missing outcome data with respect to the clinical outcomes.

\section{Selective reporting}

We systematically compared planned and reported outcomes in ten studies that provided a prospectively published protocol (Heart positive 2011) or prospectively published registry record (ALPINESVG 2015; Carotid IMT 2008; Guyton 2008; Heart positive 2011; HPS2-THRIVE 2014; Lee 2009; Maccubbin 2008; MacLean 2011; NIA Plaque 2013). Of these, we judged the risk of outcome reporting bias as high for one study that failed to report pre-specified cardiovascular events (NIA Plaque 2013). The trials ALPINE-SVG 2015, AIM-HIGH 2011, and HPS2-THRIVE 2014 reported all prespecified outcomes and were therefore judged as being at low risk of reporting bias. We judged the risk of reporting bias in the remaining five trials with a prospective protocol as unclear because the clinical outcomes that we extracted (e.g. death or flushing) were reported as side effects but not pre-specified as separate outcomes. The risk of reporting bias was unclear for the 13 trials without published protocol or registry record (Figure 2).

\section{Other potential sources of bias}

We considered Sang 2009 at high risk of bias because the reported information was insufficient to rate any item of the risk of bias tool. In addition, treatment groups were considerably unbalanced with respect to cardiovascular risk factors, prior myocardial infarction (control: 36\%, intervention 10\%) and diabetes (control: 16\%, intervention 54\%) which raises doubts whether the method of randomisation was appropriate.

One trial was stopped early for futility (AIM-HIGH 2011). It has been argued that stopping early for futility bears a potential risk for underestimation of potential treatment effects (Walter 2017). However, we considered a relevant bias extremely unlikely given the conservative stopping rules and point estimates consistently excluding any benefits.

\section{Effects of interventions}

See: Summary of findings for the main comparison Niacin for primary and secondary prevention of cardiovascular events

\section{Primary outcome}

Twelve RCTs reported the primary outcome of overall mortality. Using available cases, we found high-quality evidence that niacin did not reduce overall mortality (RR $1.05,95 \% \mathrm{Cl} 0.97$ to 1.12; participants $=35,543 ;$ studies $=12 ; 1^{2}=0 \%$; Analysis 1.1$)$. The sensitivity analyses using relatively extreme assumptions for imputation of missing data did not change the primary outcome (Table 1). When we considered only the two trials at low risk of bias (AIM-HIGH 2011 and HPS2-THRIVE 2014) as a sensitivity analysis, the pooled results suggested that niacin may increase overall mortality (RR $1.10,95 \% \mathrm{Cl} 1.00$ to 1.20 ; participants $=28,840$; studies $=2 ; 12=0 \%$ Analysis 1.2).

Meta-regression analyses did not suggest a significant effect modification by duration of treatment $(P=0.15$, Figure 3$)$, proportion of participants with established coronary heart disease $(P=0.19$, Figure 4$)$, or proportion of participants receiving background statin therapy $(P=0.15$, Figure 5$)$. 
Figure 3. Meta-regression by duration of treatment using the 'matreg' command in Stata version 13 (stata.com) (Number of observations: 12, $\mathrm{P}=\mathbf{0 . 1 5}$ )

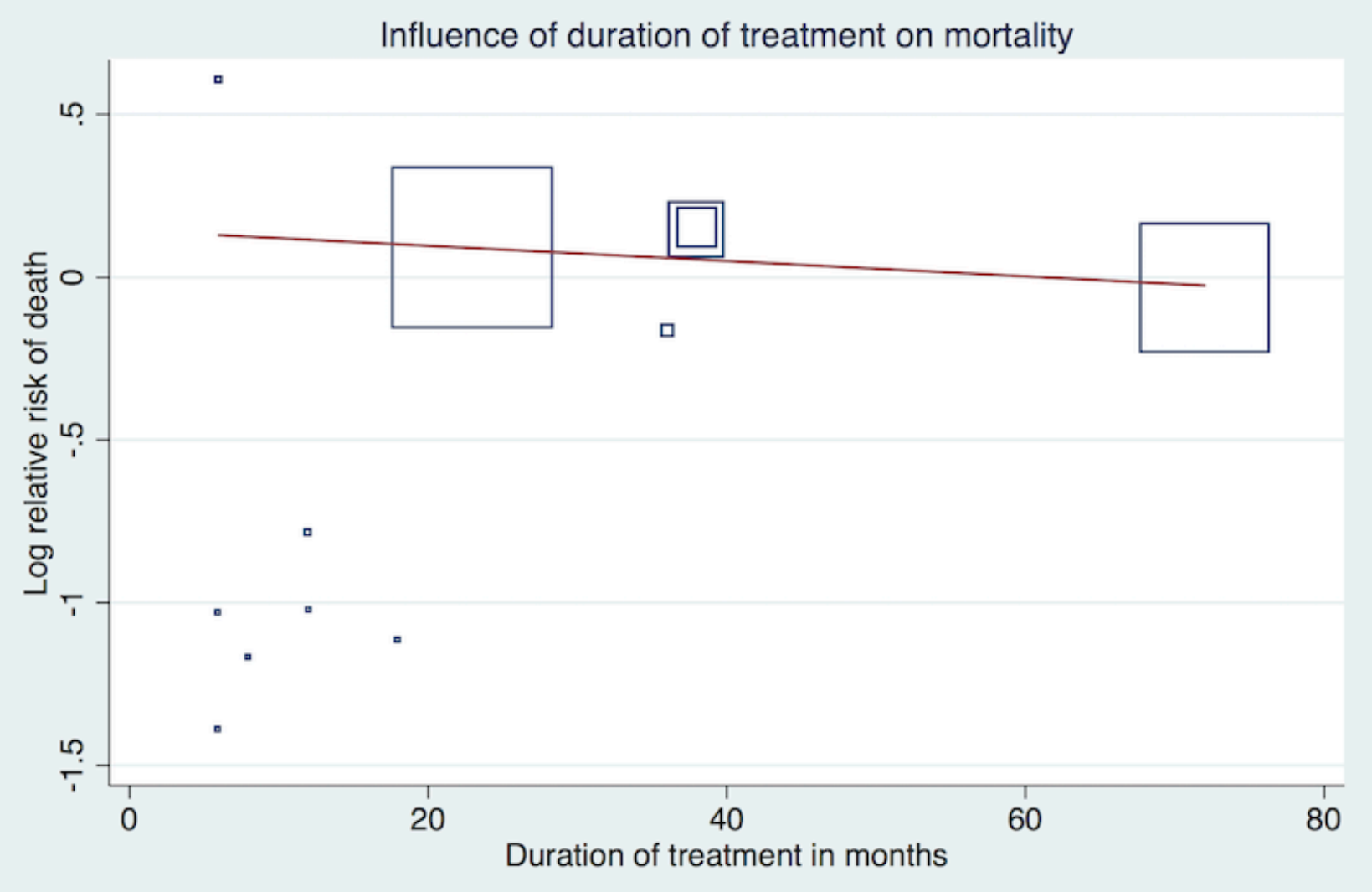


Figure 4. Meta-regression by proportion of participants with prior myocardial infarction using the 'matreg' command in Stata version 13 (stata.com) (Number of observations:8, $P=0.19$ )

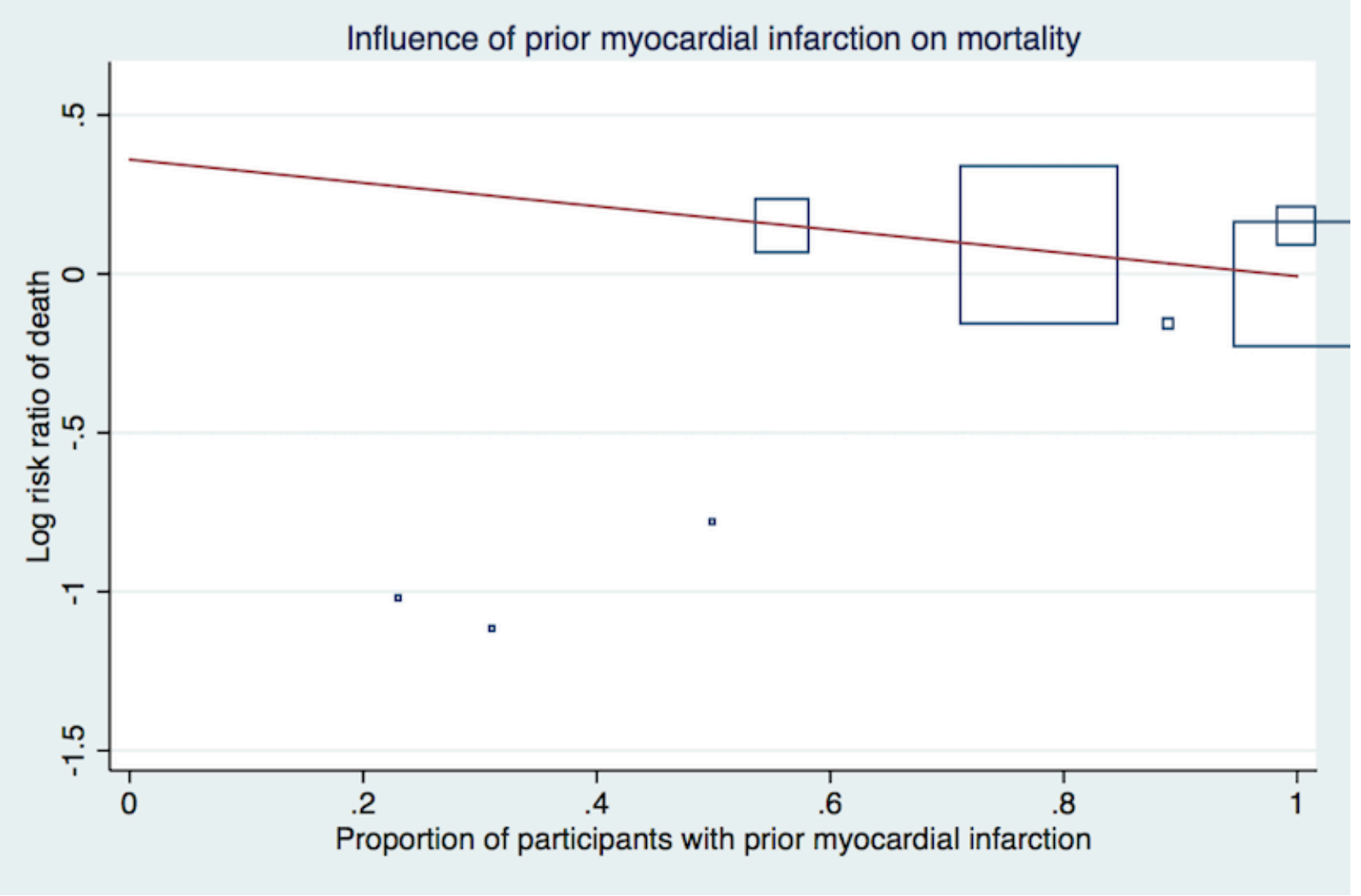


Figure 5. Meta-regression by proportion of participants receiving background statin therapy using the 'matreg' command in Stata version 13 (stata.com) (Number of observations: 10, $P=0.15$ )

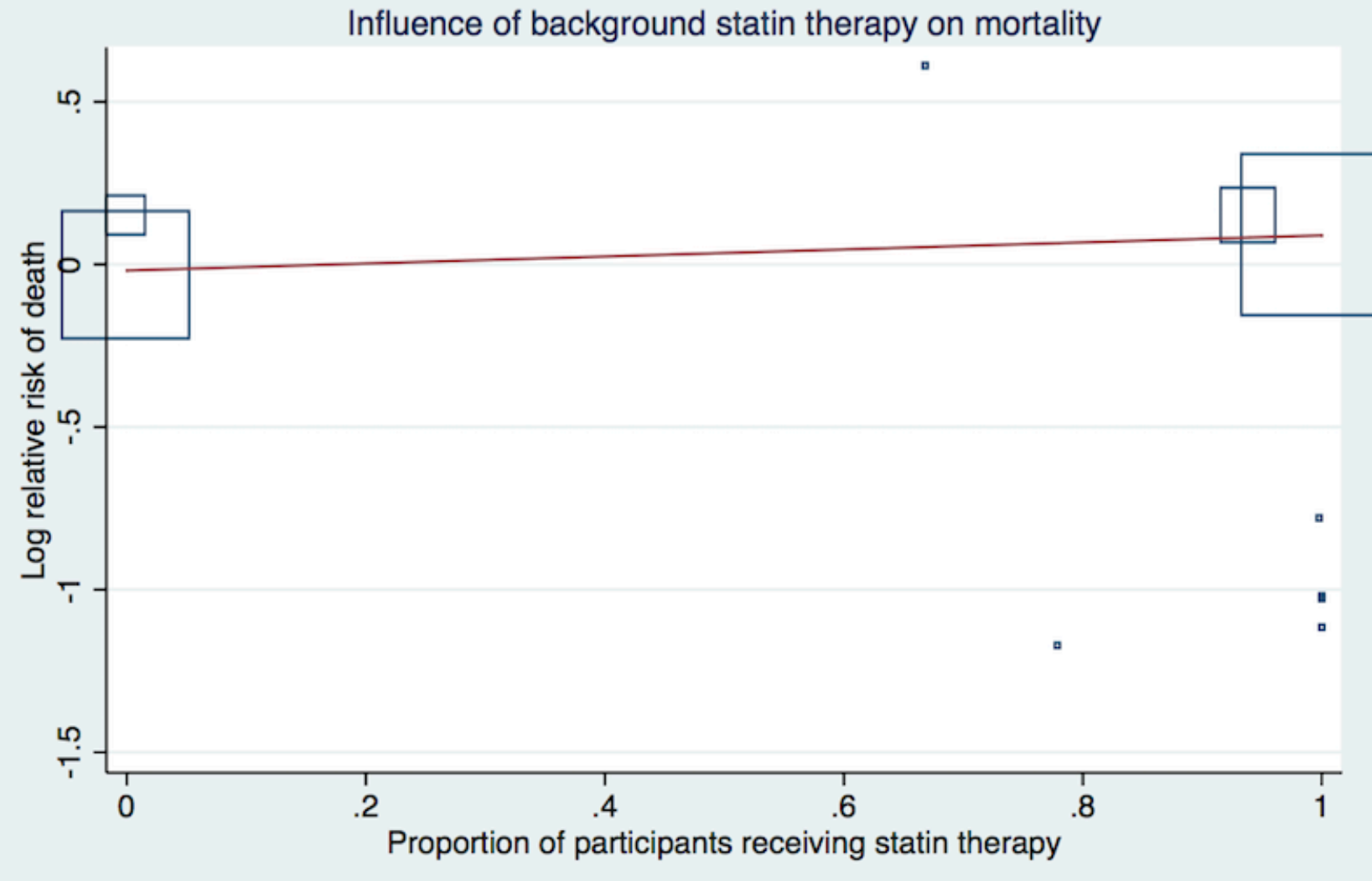

\section{Secondary outcomes}

The effect of niacin was not significant in any cardiovascular outcome.

Using available cases, niacin did not reduce:

- the number of fatal myocardial infarctions (RR 1.01, 95\% Cl 0.91 to 1.11 ; participants $=33,336$; studies $=6 ; 1^{2}=0 \%$, moderatequality evidence, downgraded due to imprecision, Analysis 1.3);

- cardiovascular mortality (RR 1.02, $95 \% \mathrm{Cl} 0.93$ to 1.12; participants $=32,966 ;$ studies $=5 ; 1^{2}=0 \%$, moderate-quality evidence, downgraded due to imprecision, Analysis 1.4);

- non-cardiovascular mortality (RR $1.12,95 \% \mathrm{Cl} 0.98$ to 1.28; participants $=32,966$; studies $=5 ;\left.\right|^{2}=0 \%$; high-quality evidence, Analysis 1.5);

- the number of non-fatal myocardial infarctions (RR 0.91, 95\% $\mathrm{Cl} 0.77$ to 1.07 ; participants $=33,164$; studies $=4 ;\left.\right|^{2}=53 \%$, low-quality evidence, downgraded due to imprecision and inconsistency, Analysis 1.6);

- the number of fatal or non-fatal myocardial infarctions (RR 0.93, $95 \% \mathrm{Cl} 0.87$ to 1.00 ; participants $=34,829$; studies $=9 ; 1^{2}=0 \%$, moderate-quality evidence, downgraded due to imprecision, Analysis 1.7);

- the number of fatal or non-fatal strokes (RR $0.95,95 \% \mathrm{Cl} 0.74$ to 1.22 ; participants $=33,661$; studies $=7 ; 1^{2}=42 \%$, low-quality evidence, downgraded due to imprecision and inconsistency, Analysis 1.8); nor

- the number of revascularisation procedures (RR $0.85,95 \% \mathrm{Cl}$ 0.68 to 1.06; participants $=33,130$; studies $=8 ; 1^{2}=45 \%$, low-quality evidence, downgraded due to imprecision and inconsistency, Analysis 1.9).

Using available cases, niacin increased the number of side effects, specifically:

- flushing (RR 7.69, 95\% Cl 4.14 to 14.28 ; participants = 11,038; studies $=15 ;\left.\right|^{2}=91 \%$, moderate-quality evidence, downgraded due to inconsistency, Analysis 1.10);

- pruritus (RR 5.26, 95\% Cl 2.68 to 10.32 ; participants = 5800; studies $=6 ; 1^{2}=66 \%$, moderate-quality evidence, downgraded due to inconsistency, Analysis 1.11);

- rash (RR 3.15, 95\% Cl 1.94 to 5.13; participants = 31,485; studies $=9 ; 1^{2}=52 \%$, moderate-quality evidence, downgraded due to inconsistency, Analysis 1.12);

- headache (RR $1.40,95 \% \mathrm{Cl} 0.86$ to 2.28; participants = 300; studies $=3 ; 1^{2}=0 \%$, moderate-quality evidence, downgraded due to imprecision, Analysis 1.13);

- gastrointestinal symptoms (RR $1.69,95 \% \mathrm{Cl} 1.37$ to 2.07 ; participants $=35,353$; studies $=12 ; 1^{2}=60 \%$, moderate-quality evidence, downgraded due to inconsistency, Analysis 1.14); and

- discontinuation of treatment due to side effects (RR 2.17, 95\% $\mathrm{Cl} 1.70$ to 2.77 ; participants $=33,539$; studies $=17 ; \mathrm{I}^{2}=77 \%$, 
moderate-quality evidence, downgraded due to inconsistency, Analysis 1.15).

The statistical heterogeneity (12) was high for the outcomes flushing, pruritus, rash, gastrointestinal symptoms, and discontinuation of treatment due to side effects, and we could not explain the heterogeneity by dose, pharmacological measures to prevent side effects, use of run-in or enrichment period, or risk of bias. Therefore, we downgraded our judgement of the quality of evidence due to statistical inconsistency. However, the consistent directions of effects and the generally large effect sizes leave no doubt that niacin does substantially increases the number of side effects. Although the exact size of the estimate is compromised by the inconsistency, the clinical implication is clear and pooling seems appropriate.

Sensitivity analyses using different assumptions for missing data did not affect the conclusion for any secondary outcome (Table 1 . We did not draw forest plots given the minimal differences and large number of sensitivity analyses.

For the outcome of new onset of diabetes, none of the three included studies reported available case analysis. Instead, we considered all randomised participants (which assumes no events for missing participants). The pooled results suggested that Niacin increased the number of participants developing diabetes (RR 1.32, $95 \% \mathrm{Cl} 1.16$ to 1.51 ; participants $=27,982$; studies $=3 ; 12=0 \%$, highquality evidence, Analysis 1.16). We did not downgrade due to risk of attrition bias because the proportion of missing data was as low as $1 \%$ in the dominating trial (HPS2-THRIVE 2014). Therefore, we considered the risk of bias to be low for the body of evidence.

None of the studies reported information about quality of life or costs.

\section{DISCUSSION}

\section{Summary of main results}

We found high-quality evidence that niacin does not reduce the risk for overall mortality. A sensitivity analysis limited to the two RCTs at low risk of bias ( 28,840 participants), suggested that niacin may even increase the number of deaths. We found no significant effect modification by duration of treatment, prior myocardial infarction, or background statin therapy.

We found moderate- to high-quality evidence that niacin does not reduce any other cardiovascular outcomes such as cardiovascular mortality, non-cardiovascular mortality, fatal myocardial infarctions, non-fatal myocardial infarction, or fatal or non-fatal myocardial infarction. Low-quality evidence suggested that niacin does not reduce the number of fatal or non-fatal strokes, or revascularisation procedures.

We found moderate-quality evidence that niacin does substantially increase the number of participants discontinuing treatment due to side effects and the number of selected side effects such as flushing, pruritus, rash, and gastrointestinal symptoms, but also the serious side effect of new onset diabetes.

\section{Overall completeness and applicability of evidence}

\section{Completeness}

We extensively searched the literature and carefully screened reference lists of relevant articles. Although we are confident that we did not miss any relevant study, potential selective outcome reporting might affect our results. First, the proportion of trials contributing to the meta-analysis for our primary outcome (overall mortality) was below $50 \%$ when we also consider the six excluded RTCs that failed to report any clinically relevant outcome (Furukawa 2007). In addition, the funnel plot of the primary outcome was asymmetrical and suggested that positive studies were more likely to be published (Figure 6). Since positive study bias would overestimate beneficial effects of niacin, it is unlikely that missing studies may have biased our conclusion that niacin is not beneficial. 
Figure 6. Funnel plot of comparison: 1 niacin over placebo, maximum follow-up, available case analysis, outcome: 1.1 overall mortality

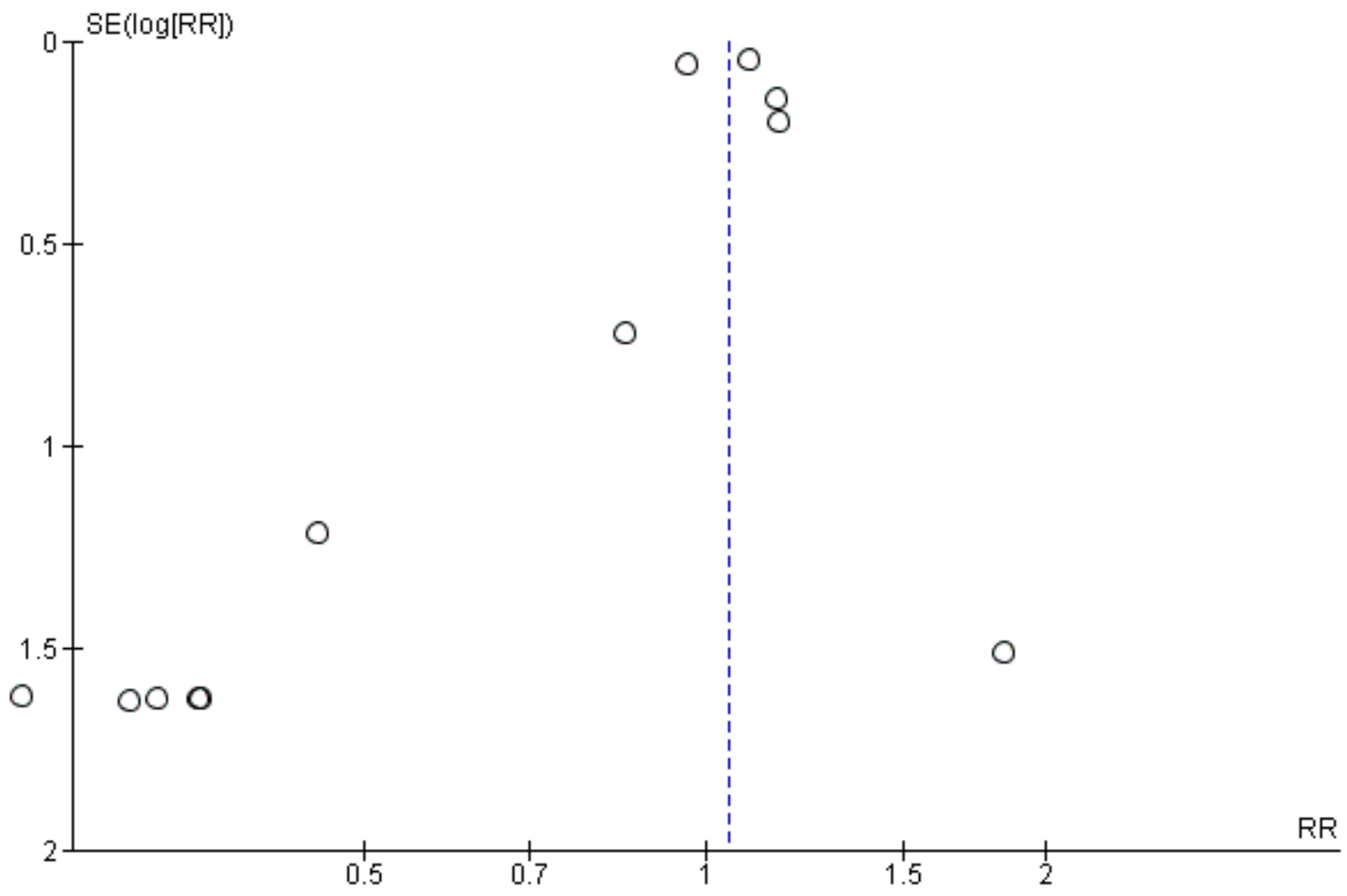

\section{Applicability}

Low heterogeneity despite considerable variety in populations suggests that the absence of beneficial effects of niacin treatment on mortality and cardiovascular outcomes are widely applicable. The generalisability is further supported by the fact that the meta-regression analyses did not show any significant association between effect estimate and duration of treatment, secondary or primary prevention, or background statin therapy. Although there was high statistical heterogeneity in side effects and discontinuation of treatment due to side effects, the clinical interpretation that niacin does substantially increase the number of side effects was consistent across studies and can be generalised.

\section{Quality of the evidence}

The meta-analyses were largely driven by one large trial at low risk of bias (HPS2-THRIVE 2014). Therefore, although we considered most trials to be at high risk of bias, mainly due to missing data, we did not downgrade any outcome for risk of bias. The results were robust in a sensitivity analysis where we made relatively extreme assumptions for missing outcome data (Table 1). Moreover, other potential sources of bias such as performance bias due to openlabel medication or detection bias through unblinded outcome assessment were unlikely to affect our conclusions because the anticipated direction of these biases would favour niacin. Following the same logic, we did not downgrade for potential publications bias; the funnel plot for the main outcome was skewed in favour of positive studies (Figure 6).
We downgraded our certainty in effects due to imprecision when the confidence interval of the overall effect included both no effect and potential benefit. When the confidence interval excluded benefit but included no effect and potential harm, we did not downgrade. The rationale for the latter approach is that the distinction between no effect and harm is irrelevant for clinical decision-making; the clinical interest lies in potential benefits of niacin.

We downgraded two outcomes for inconsistency. Overall, the quality of evidence ranged between high and moderate; quality was low only for the stroke outcome.

\section{Potential biases in the review process}

We screened all potentially relevant abstracts and full texts in duplicate and extracted included studies in duplicate. A potential limitation is that we did not systematically search the grey literature and did not systematically contact authors of identified studies for additional unpublished data. However, given the lack of significant benefits of niacin therapy, the large number of participants in our meta-analysis, and the low heterogeneity, only a large trial demonstrating a clear benefit could affect the conclusions. It is unlikely that we missed such a trial.

We made a number of (conservative) assumptions when outcome details were not clearly reported, as specified under data synthesis. A survey of investigators would have been optimal. However, the reporting quality of the main trial (HPS2-THRIVE 2014) was high and 
the potential risk of bias introduced by these assumptions therefore minimal.

\section{Agreements and disagreements with other studies or reviews}

Our conclusions are in line with the conclusions of related metaanalyses. Ip 2015 reported a potentially harmful effect of niacin on overall mortality when niacin is administered on top of background statin treatment in high-risk participants (RR $1.10,95 \% \mathrm{Cl} 1.00$ to $1.20,12=0 \%$ ), which is identical to our estimate based on the two trials at low risk of bias. Regarding new onset of diabetes, a recent meta-analysis (Goldie 2015) found that "Niacin therapy was associated with an increase of new onset diabetes of RR 1.34 (95\% Cls 1.21 to 1.49 )". Although Goldie et at included RCTs evaluating niacin combination therapy, the estimate was very similar to our estimate (RR $1.32,95 \% \mathrm{Cl} 1.16$ to $1.51, \mathrm{I} 2=0 \%$ ).

\section{AUTHORS' CONCLUSIONS}

\section{Implications for practice}

In summary, moderate- to high-quality evidence suggests that niacin does not reduce mortality or cardiovascular events. Our confidence is increased by the fact that none of the outcomes showed a significant benefit, despite potential biases in favour of
Niacin. Niacin cannot be recommended for primary or secondary prevention of cardiovascular events.

\section{Implications for research}

No further research is required to evaluate the role of niacin in the prevention of cardiovascular events. The body of evidence appears sufficient to conclude that niacin has no role in the primary or secondary prevention of cardiovascular events, not as mono nor as add-on therapy. Considering the potential increase in overall mortality, as suggested by two large trials at low risk of bias, additional randomised controlled trials in similar populations would be unethical.

\section{ACKNOWLEDGEMENTS}

We would like to thank Neera Bhatnagar, research librarian at the Department of Clinical Epidemiology and Biostatistics, Hamilton, Canada, for designing and conducting an initial electronic search, Aviv Ladanie at the Basel Institute for Clinical Epidemiology and Biostatistics for his assistance with Stata, and Benjamin Kasenda for his contribution to the protocol and screening of titles and abstracts. Furthermore we would like to thank Cochrane Heart for designing and conducting the final electronic searches and the constructive feedback on our manuscript. 


\section{R E F E R E N C E S}

\section{References to studies included in this review}

ADMIT 2000 \{published data only\}

Chesney CM, Elam MB, Herd JA, Davis KB, Garg R, Hunninghake $D$, et al. Effect of niacin, warfarin, and antioxidant therapy on coagulation parameters in patients with peripheral arterial disease in the Arterial Disease Multiple Intervention Trial (ADMIT). American Heart Journal 2000;140:631-6.

Egan DA, Garg R, Wilt TJ, Pettinger MB, Davis KB, Crouse J, et al. Rationale and design of the Arterial Disease Multiple Intervention Trial (ADMIT) pilot study. American Journal of Cardiology 1999;83:569-75.

* Elam MB, Hunninghake DB, Davis KB, Garg R, Johnson C, Egan D, et al. Effect of niacin on lipid and lipoprotein levels and glycemic control in patients with diabetes and peripheral arterial disease: the ADMIT study: a randomised trial. Arterial Disease Multiple Intervention Trial. JAMA 2000;284:1263-70.

Garg R, Elam MB, Crouse JR 3rd, Davis KB, Kennedy JW, Egan D, et al. Effective and safe modification of multiple atherosclerotic risk factors in patients with peripheral arterial disease. American Heart Journal 2000;140:792-803.

Garg R, Malinow M, Pettinger M, Upson B, Hunninghake D. Niacin treatment increases plasma homocyst(e)ine levels. American Heart Journal 1999;138:1082-7.

\section{AIM-HIGH 2011 \{published data only\}}

Albers JJ, Slee A, O'Brien KD, Robinson JG, Kashyap ML, Kwiterovich PO Jr, et al. Relationship of apolipoproteins A-1 and $\mathrm{B}$, and lipoprotein (a) to cardiovascular outcomes: the AIM-HIGH trial (Atherothrombosis Intervention in Metabolic Syndrome with Low HDL/High Triglyceride and Impact on Global Health Outcomes). Journal of the American College of Cardiology 2013;62:1575-9.

Bays H, Giezek H, McKenney JM, O'Neill EA, Tershakovec AM. Extended-release niacin/laropiprant effects on lipoprotein subfractions in patients with type 2 diabetes mellitus. Metabolic Syndrome and Related Disorders 2012;10:260-6.

Boden WE, Probstfield JL. Extended-release niacin does not reduce clinical events in patients with established cardiovascular disease whose LDL-cholesterol is optimally controlled with statin therapy: results from the AIM-HIGH trial. Circulation 2011;124:2370.

* Boden WE, Probstfield JL, Anderson T, Chaitman BR, Desvignes-Nickens P, Koprowicz K, et al. Niacin in patients with low $\mathrm{HDL}$ cholesterol levels receiving intensive statin therapy. New England Journal of Medicine 2011;365:2255-67.

Goldberg RB, Bittner VA, Dunbar RL, Fleg JL, Grunberger G, Guyton JR, et al. Effects of extended-release niacin added to simvastatin/ezetimibe on glucose and insulin values in AIMHIGH. American Journal of Medicine 2016;129(7):10.

Guyton JR, Slee AE, Anderson T, Fleg JL, Goldberg RB, Kashyap ML, et al. Relationship of lipoproteins to cardiovascular events: the AIM-HIGH Trial (Atherothrombosis Intervention in Metabolic Syndrome With Low HDL/High Triglycerides and Impact on Global Health Outcomes). Journal of the American College of Cardiology 2013;62:1580-4.

Investigators Aim-High. The role of niacin in raising highdensity lipoprotein cholesterol to reduce cardiovascular events in patients with atherosclerotic cardiovascular disease and optimally treated low-density lipoprotein cholesterol: baseline characteristics of study participants. The Atherothrombosis Intervention in Metabolic syndrome with low HDL/high triglycerides: impact on Global Health outcomes (AIM-HIGH) trial. American Heart Journal 2011;161:538-43.

Kalil RS, Wang JH, De Boer IH, Mathew RO, Ix JH, Asif A, et al. Effect of extended-release niacin on cardiovascular events and kidney function in chronic kidney disease: a post hoc analysis of the AIM-HIGH trial. Kidney International 2015;87:1250-7.

Le NA, Farkas-Epperson M, Jin R, Tershakovec AM, Neff DR, Wolfert $\mathrm{R}$, et al. Changes in lipoprotein-associated phospholipase A2 with ezetimibe/simvastatin co-administered with ER niacin in type II hyperlipidemia. Journal of Clinical Lipidology 2012;6:253-4.

Lyubarova R, Marcovina S, Fleg J, Nickens P D, Topliceanu A, Yao $Y$, et al. Effects of extended-release niacin on lipoproteinassociated phospholipase A2 levels and clinical outcomes in patients with established cardiovascular disease and low baseline levels of HDL-cholesterol: post hoc analysis of the AIM-HIGH trial. Journal of the American College of Cardiology 2016;1:2080.

Teo KK, Goldstein LB, Chaitman BR, Grant S, Weintraub WS, Anderson DC, et al. Extended-release niacin therapy and risk of ischemic stroke in patients with cardiovascular disease: the Atherothrombosis Intervention in Metabolic Syndrome with low HDL/High Triglycerides: Impact on Global Health Outcome (AIMHIGH) trial. Stroke 2013;44:2688-93.

Toth P P, Jones S, Slee A, Marcovina S, Fleg J, Boden W. Differential treatment effects of extended-release niacin and placebo on baseline and one-year lipoprotein subfractions and their relationship to cardiovascular outcomes: Post hoc subset analysis of aim-high trial patients with high triglyceride and low HDL-C. Journal of the American College of Cardiology 2016;1):2130.

Toth PP, Jones S, Slee A, Fleg J, Marcovina S, Boden W. Association between baseline lipoprotein subfractions and outcomes in patients with high triglyceride and low HDLcholesterol levels: a post hoc subgroup analysis of the AIM-HIGH trial. Journal of the American College of Cardiology 2016;1:2000.

Toth PP, Jones S, Slee A, Fleg J, Marcovina S, Boden W, et al. Association between baseline lipoprotein subfractions and outcomes in patients with high triglyceride and low HDLcholesterol levels: A post hoc subgroup analysis of the AIM-HIGH trial. Journal of the American College of Cardiology 2016; Vol. 67 , issue 13:1236.

Toth PP, Jones S, Slee A, Marcovina S, Fleg J, Boden W, et al. Differential treatment effects of extended-release niacin and 
placebo on baseline and one-year lipoprotein subfractions and their relationship to cardiovascular outcomes: Post hoc subset analysis of aim-high trial patients with high triglyceride and low HDL-C. Journal of the American College of Cardiology 2016; Vol. 67 , issue 13:2130.

\section{ALPINE-SVG 2015 \{published data only\}}

* Guerra A, Rangan B V, Coleman A, Xu H, Kotsia A, Christopoulos $\mathrm{G}$, et al. Effect of extended-release niacin on carotid intima media thickness, reactive hyperemia, and endothelial progenitor cell nobilization: insights from the Atherosclerosis Lesion Progression Intervention Using Niacin Extended Release in Saphenous Vein Grafts (ALPINE-SVG) pilot trial. Journal of Invasive Cardiology 2015;27(12):555-60.

Kotsia AP, Rangan BV, Christopoulos G, Coleman A, Roesle M, Cipher D, et al. Effect of extended-release niacin on saphenous vein graft atherosclerosis: insights from the Atherosclerosis Lesion Progression Intervention Using Niacin Extended Release in Saphenous Vein Grafts (ALPINE-SVG) pilot trial. Journal of Invasive Cardiology 2015;27(10):E204-10.

\section{ARBITER-2 2004 \{published data only\}}

Taylor AJ, Stanek EJ. Flushing and the HDL-C response to extended-release niacin. Journal of Clinical Lipidology 2008;2:285-8.

* Taylor AJ, Sullenberger LE, Lee HJ, Lee JK, Grace KA. Arterial biology for the investigation of the treatment effects of reducing cholesterol (ARBITER) 2: a double-blind, placebocontrolled study of extended-release niacin on atherosclerosis progression in secondary prevention patients treated with statins. Circulation 2004;110:3512-7.

\section{Capuzzi 2003 \{published data only\}}

Capuzzi DM, Morgan JM, Carey CM, Intenzo C, Tulenko T, Kearney $\mathrm{D}$, et al. Rosuvastatin alone or with extended-release niacin: a new therapeutic option for patients with combined hyperlipidemia. Preventive Cardiology 2004;7:176-81.

* Capuzzi DM, Morgan JM, Weiss RJ, Chitra RR, Hutchinson HG, Cressman MD. Beneficial effects of rosuvastatin alone and in combination with extended-release niacin in patients with a combined hyperlipidemia and low high-density lipoprotein cholesterol levels. American Journal of Cardiology 2003;91:1304-10.

\section{Carotid IMT 2008 \{published data only\}}

NCT00384293. Carotid IMT (Intima Media Thickening) Study (0524A-041)(TERMINATED) (ACHIEVE). clinicaltrials.gov/ct2/ show/NCT00384293 (accessed 12 January 2016).

\section{CDP 1975 \{published data only\}}

Berge KG, Canner PL. Coronary Drug Project: experience with niacin. European Journal of Clinical Pharmacology 1991;40 Suppl 1:S49-51.

CDP-Group. The Coronary Drug Project. JAMA 1970;214:1303.

CDP-Group. The Coronary Drug Project. Findings leading to further modifications of its protocol with respect to dextrothyroxine. The Coronary Drug Project Research Group. JAMA 1972;220:996-1008.

Canner PL, Berge KG, Wenger NK, Stamler J, Friedman L, Prineas RJ, et al. Fifteen year mortality in Coronary Drug Project patients: long-term benefit with niacin. Journal of the American College of Cardiology 1986;8:1245-55.

Canner PL, Furberg CD, McGovern ME. Benefits of niacin in patients with versus without the metabolic syndrome and healed myocardial infarction (from the Coronary Drug Project). American Journal of Cardiology 2006;97:477-9.

* The Coronary Drug Project Research Group. Clofibrate and niacin in coronary heart disease. JAMA 1975;231:360-81.

\section{Goldberg 2000 \{published data only\}}

* Goldberg A, Alagona P Jr, Capuzzi DM, Guyton J, Morgan JM, Rodgers J, et al. Multiple-dose efficacy and safety of an extended-release form of niacin in the management of hyperlipidemia. American Journal of Cardiology 2000;85:1100-5.

Goldberg AC. Clinical trial experience with extended-release niacin (Niaspan): dose-escalation study. American Journal of Cardiology 1998;82:35U-38U; discussion 39U-41U.

\section{Guyton 2008 \{published data only\}}

Brown WV, Fazio S, Guyton JR, Dong Q, Tomassini JE, Shah A, et al. 59 relationships between hsCRP reduction and LDLC, nonHDL-C, APOB and HDL-C in hyperlipidemic patients treated with ezetimibe/simvastatin + extended-release niacin. Atherosclerosis Supplements 2011;12:14.

Fazio S, Guyton JR, Lin J, Tomassini JE, Shah A, Tershakovec AM. 82 combination ezetimibe/simvastatin + extended-release niacin therapy improves attainment of recommended LDLC, Non-HDL-C and APOB levels in hyperlipidemic patients. Atherosclerosis Supplements 2011;12:20.

Fazio S, Guyton JR, Lin J, Tomassini JE, Shah A, Tershakovec AM. Combination ezetimibe/simvastatin plus extended-release niacin therapy improves attainment of recommended LDLC, NON-HDL-C and APOB levels in hyperlipidemic patients. Atherosclerosis Supplements 2011;12:20.

Fazio S, Guyton JR, Lin J, Tomassini JE, Shah A, Tershakovec AM. Long-term efficacy and safety of ezetimibe/simvastatin coadministered with extended-release niacin in hyperlipidaemic patients with diabetes or metabolic syndrome. Diabetes, Obesity \& Metabolism 2010;12:983-93.

Fazio S, Guyton JR, Polis AB, Adewale AJ, Tomassini JE, Ryan NW, et al. Long-term safety and efficacy of triple combination ezetimibe/simvastatin plus extended-release niacin in patients with hyperlipidemia. American Journal of Cardiology 2010;105:487-94.

* Guyton JR, Brown BG, Fazio S, Polis A, Tomassini JE, Tershakovec AM. Lipid-altering efficacy and safety of ezetimibe/ simvastatin coadministered with extended-release niacin in patients with type Ila or type IIb hyperlipidemia. Journal of the American College of Cardiology 2008;51:1564-72. 
Guyton JR, Fazio S, Adewale AJ, Jensen E, Tomassini JE, Shah A, et al. Effect of extended-release niacin on new-onset diabetes among hyperlipidemic patients treated with ezetimibe/ simvastatin in a randomised controlled trial. Diabetes Care 2012;35:857-60.

Guyton JR, Fazio S, Adewale AJ, Jensen EH, Tomassini JE, Shah A, et al. New onset diabetes mellitus among patients with type Ila/Ilb hyperlipidemia (HL) taking ezetimibe/simvastatin (E/S) +/- niacin (N): a randomized trial. Diabetes 2009;58:A191.

\section{Harikrishnan 2008 \{published data only\}}

Harikrishnan S, Rajeev E, Tharakan JA, Titus T, Ajit Kumar VK, Sivasankaran S, et al. Efficacy and safety of combination of ER niacin and atorvastatin in patients with low levels of high density lipoprotein cholesterol. Indian Heart Journal 2008;60:215-22.

\section{Heart positive 2011 \{published data only\}}

* Balasubramanyam A, Coraza I, Smith EO, Scott LW, Patel P, lyer D, et al. Combination of niacin and fenofibrate with lifestyle changes improves dyslipidemia and hypoadiponectinemia in HIV patients on antiretroviral therapy: results of "Heart Positive," a randomised, controlled trial. Journal of Clinical Endocrinology and Metabolism 2011;96:2236-47.

Samson SL, Pownall HJ, Scott LW, Ballantyne CM, Smith EO, Sekhar RV, et al. Heart Positive: design of a randomised controlled clinical trial of intensive lifestyle intervention, niacin and fenofibrate for HIV lipodystrophy/dyslipidemia. Contemporary Clinical Trials 2006;27:518-30.

\section{HPS2-THRIVE 2014 \{published data only\}}

Ballantyne CM, Bays HE, Shah AK, Sisk C, Dong Q, Maccubbin D. 106 extended release niacin/laropiprant lowers atherogenic lipids across patient subgroups. Atherosclerosis Supplements 2011;12:25.

Bays HE, MacLean A, Shah A, McCrary Sisk C, Dong Q, Maccubbin D. The lipid-altering effects of extended-release niacin/laropiprant among different patient subgroups. Journal of Clinical Lipidology 2010;4:215.

Bays HE, Maccubbin D, Meehan AG, Kuznetsova O, Mitchel YB, Paolini JF. Blood pressure-lowering effects of extendedrelease niacin alone and extended-release niacin/laropiprant combination: a post hoc analysis of a 24-week, placebocontrolled trial in dyslipidemic patients. Clinical Therapy 2009;31:115-22.

Bays HE, Shah A, Lin J, McCrary Sisk C, Paolini JF, Maccubbin D. Efficacy and tolerability of extended-release niacin/laropiprant in dyslipidemic patients with metabolic syndrome. Journal of Clinical Lipidology 2010;4:515-21.

Bostom AG, MacLean AA, Maccubbin D, Tipping D, Gizek H, Hanlon W. Extended release niacin/laropiprant lowers serum phosphorus concentrations in patients with type 2 diabetes and mild hyperphosphatemia. Arteriosclerosis Thrombosis and Vascular Biology 2010;30:E200.

Group HPS-THRIVE Collaborative. HPS2-THRIVE randomised placebo-controlled trial in 25673 high-risk patients of ER niacin/laropiprant: trial design, pre-specified muscle and liver outcomes, and reasons for stopping study treatment. European Heart Journal 2013;34:1279-91.

* Group HPS-THRIVE Collaborative, Landray MJ, Haynes R, Hopewell JC, Parish S, Aung T, et al. Effects of extended-release niacin with laropiprant in high-risk patients. New England Journal of Medicine 2014;371:203-12.

Hopewell JC, Offer A, Parish S, Haynes R, Li J, Jiang L, et al. Environmental and genetic risk factors for myopathy in Chinese participants from HPS2-THRIVE. European Heart Journal 2012;33:445.

Mitchel Y. Abstracts of the 48th EASD (European Association for the Study of Diabetes) Annual Meeting of the European Association for the Study of Diabetes. October 1-5, 2012. Berlin, Germany. Diabetologia 2012;55 Suppl 1:S7-537.

Mitchel Y, Brinton E, Triscari J, Chen E, Johnson-Levonas AO, Ruck R, et al. Effects of extended-release niacin/laropiprant (ERN/LRPT) on apolipoprotein (apo) B, LDL-cholesterol, and non-HDL-cholesterol targets in patients with type 2 diabetes. Diabetologia 2012;55:S500-1.

\section{Hunninghake 2003 \{published data only\}}

Hunninghake DB, McGovern ME, Koren M, Brazg R, Murdock D, Weiss $S$, et al. A dose-ranging study of a new, once-daily, dualcomponent drug product containing niacin extended-release and lovastatin. Clinical Cardiology 2003;26:112-8.

\section{Lee 2009 \{published data only\}}

Lee JM, Robson MD, Yu LM, Shirodaria CC, Cunnington C, Kylintireas I, et al. Effects of high-dose modified-release nicotinic acid on atherosclerosis and vascular function: a randomised, placebo-controlled, magnetic resonance imaging study. Journal of the American College of Cardiology 2009;54:1787-94.

\section{Lee 2011 \{published data only\}}

Lee K, Ahn TH, Kang WC, Han SH, Choi IS, Shin EK. The effects of statin and niacin on plaque stability, plaque regression, inflammation and oxidative stress in patients with mild to moderate coronary artery stenosis. Korean Circulation Journal 2011;41:641-8.

\section{Linke 2009 \{published data only\}}

Linke A, Sonnabend M, Fasshauer M, Hollriegel R, Schuler G, Niebauer J, et al. Effects of extended-release niacin on lipid profile and adipocyte biology in patients with impaired glucose tolerance. Atherosclerosis 2009;205:207-13.

\section{Maccubbin 2008 \{published data only\}}

Maccubbin D, Bays HE, Olsson AG, Elinoff V, Elis A, Mitchel Y, et al. Lipid-modifying efficacy and tolerability of extendedrelease niacin/laropiprant in patients with primary hypercholesterolaemia or mixed dyslipidaemia. International Journal of Clinical Practice 2008;62:1959-70.

\section{MacLean 2011 \{published data only\}}

Bays HE, Brinton EA, Triscari J, Chen E, Maccubbin D, MacLean A, et al. Extended-release niacin/laropiprant 
significantly improves lipid levels in type 2 diabetes patients irrespective of baseline glycemic control. Journal of Clinical Lipidology 2012;6:270-1.

* MacLean A, McKenney JM, Scott R, Brinton E, Bays HE, Mitchel YB, et al. Efficacy and safety of extended-release niacin/ laropiprant in patients with type 2 diabetes mellitus. British Journal of Cardiology 2011;18:37-45 ST.

\section{Nash 2011 \{published data only\}}

Nash MS, Lewis JE, Dyson-Hudson TA, Szlachcic Y, Yee F, Mendez AJ, et al. Extended-release niacin for treatment of dyslipidemia in chronic tetraplegia. Journal of Spinal Cord Medicine 2010;33(2):170 ST.

* Nash MS, Lewis JE, Dyson-Hudson TA, Szlachcic Y, Yee F, Mendez AJ, et al. Safety, tolerance, and efficacy of extendedrelease niacin monotherapy for treating dyslipidemia risks in persons with chronic tetraplegia: a randomised multicentre controlled trial. Archives of Physical Medicine and Rehabilitation 2011;92:399-410.

\section{NIA Plaque 2013 \{published data only\}}

Godoy GK, Chahal H, Fernandes VR, Sibley C, Chamera E, Bluemke $\mathrm{D}$, et al. Lipid modifying therapy and aortic wall thickness regression by magnetic resonance imaging (MRI): the plaque follow up study by the National Institute of Aging (NIA). Journal of Cardiovascular Magnetic Resonance 2010;12:068.

* Sibley CT, Vavere AL, Gottlieb I, Cox C, Matheson M, Spooner A, et al. MRI-measured regression of carotid atherosclerosis induced by statins with and without niacin in a randomised controlled trial: the NIA plaque study. Heart 2013;99:1675-80.

\section{PAST 1995 \{published data only\}}

Caruzzo C, Liboni W, Bonzano A, Bobbio M, Bongioanni S, Caruzzo E, et al. Effect of lipid-lowering treatment on progression of atherosclerotic lesions--a duplex ultrasonographic investigation. Angiology 1995;46:269-80.

\section{Sang 2009 \{published data only\}}

Sang ZC, Wang F, Zhou Q, Li YH, Li YG, Wang HP, et al. Combined use of extended-release niacin and atorvastatin: safety and effects on lipid modification. Chinese Medicine Journal 2009;122:1615-20.

\section{Schoch 1968 \{published data only\}}

Schnaper HW, Schoch HK, Detre K. Veterans administration cardiology drug-lipid study - a progress report. Circulation 1969;40:I180-\&.

* Schoch HK. The US veterans administration cardiology drug-lipid study: an interim report. Advances in Experimental Medicine and Biology 1968:405-20.

\section{References to studies excluded from this review \\ AFREGS 2005 \{published data only\}}

Devendra GP, Whitney EJ, Krasuski RA. Impact of increases in high-density lipoprotein cholesterol on cardiovascular outcomes during the armed forces regression study.
Journal of Cardiovascular Pharmacolology and Therapeutics 2010;15:380-3.

* Whitney EJ, Krasuski RA, Personius BE, Michalek JE, Maranian AM, Kolasa MW, et al. A randomised trial of a strategy for increasing high-density lipoprotein cholesterol levels: effects on progression of coronary heart disease and clinical events. Annals of Internal Medicine 2005;142:95-104.

Airan-Javia 2009 \{published data only\}

* Airan-Javia SL, Wolf RL, Wolfe ML, Tadesse M, Mohler E, Reilly MP. Atheroprotective lipoprotein effects of a niacinsimvastatin combination compared to low- and high-dose simvastatin monotherapy. Americal Heart Journal 2009;157:687 e1-8.

Khera AV, Patel PJ, Reilly MP, Rader DJ. The addition of niacin to statin therapy improves high-density lipoprotein cholesterol levels but not metrics of functionality. Journal of the American College of Cardiology 2013;62:1909-10.

\section{ARBITER-6 2009 \{published data only\}}

Devine PJ, Turco MA, Taylor AJ. Design and rationale of the ARBITER 6 trial (Arterial Biology for the Investigation of the Treatment Effects of Reducing Cholesterol)-6-HDL and LDL Treatment Strategies in Atherosclerosis (HALTS). Cardiovascular Drugs and Therapy 2007;21:221-5.

Farmer JA. Effect of extended-release niacin or ezetimibe on carotid intimal thickness: the ARBITER-HALTS Study. Current Atherosclerosis Reports 2010;12:285-7.

* Taylor AJ, Villines TC, Stanek EJ, Devine PJ, Griffen L, Miller M, et al. Extended-release niacin or ezetimibe and carotid intima-media thickness. New England Journal of Medicine 2009;361:2113-22.

Villines TC, Stanek EJ, Devine PJ, Turco M, Miller M, Weissman NJ, et al. The ARBITER 6-HALTS Trial (Arterial Biology for the Investigation of the Treatment Effects of Reducing Cholesterol 6-HDL and LDL Treatment Strategies in Atherosclerosis): final results and the impact of medication adherence, dose, and treatment duration. Journal of the American College of Cardiolpgy 2010;55:2721-6.

\section{Arntz 2000 \{published data only\}}

Arntz HR, Agrawal R, Wunderlich W, Schnitzer L, Stern R, Fischer F, et al. Beneficial effects of pravastatin (+/colestyramine/niacin) initiated immediately after a coronary event (the randomised Lipid-Coronary Artery Disease (L-CAD) Study). American Journal of Cardiology 2000;86:1293-8.

\section{Aronov 2001 \{published data only\}}

Aronov DM, Oganov RG, Keenan JM, Boubnova MG, Perova NV, Olferiev AM, et al. Effect of pravastatin and nicotinic acid on postprandial dyslipidemia in patients with coronary heart disease. Atherosclerosis Supplements 2001;2:93.

Bays 2003 \{published data only\}

Bays Harold. Combination niacin and statin therapy compared with monotherapy. Cardiology Review 2003;20:34-7. 
Blankenhorn 1987 \{published data only\}

Blankenhorn DH, Nessim SA, Johnson RL, Sanmarco ME, Azen SP, Cashin-Hemphill L. Beneficial effects of combined colestipol-niacin therapy on coronary atherosclerosis and coronary venous bypass grafts. JAMA 1987;257:3233-40.

\section{Brown 1990a \{published data only\}}

Brown G, Albers JJ, Fisher LD, Schaefer SM, Lin JT, Kaplan C, et al. Regression of coronary artery disease as a result of intensive lipid-lowering therapy in men with high levels of apolipoprotein B. Nwe England Journal of Medicine 1990;323:1289-98.

\section{Cefali 2006 \{published data only\}}

Cefali EA, Simmons PD, Stanek EJ, Shamp TR. Improved control of niacin-induced flushing using an optimized once-daily, extended-release niacin formulation. International Journal of Clinical Pharmacology and Therapeutics 2006;44:633-40.

\section{Cheung 2001a \{published data only\}}

Cheung MC, Wolfbauer G, Kennedy H, Brown BG, Albers JJ. Plasma phospholipid transfer protein activity in patients with low HDL and cardiovascular disease treated with simvastatin and niacin. Biochimica et Biophysica Acta 2001;1537:117-24.

\section{Cheung 2001b \{published data only\}}

Cheung MC, Zhao XQ, Chait A, Albers JJ, Brown BG. Antioxidant supplements block the response of HDL to simvastatinniacin therapy in patients with coronary artery disease and low HDL. Arteriosclerosis, Thrombosis, and Vascular Biology 2001;21:1320-6.

\section{Dishy 2009 \{published data only\}}

Dishy V, Liu F, Ebel DL, Atiee GJ, Royalty J, Reilley S, et al. Effects of aspirin when added to the prostaglandin D2 receptor antagonist laropiprant on niacin-induced flushing symptoms. Journal of Clinical Pharmacology 2009;49:416-22.

\section{Dunbar 2009 \{published data only\}}

Dunbar RL, Gadi R, Mitta S, Rader DJ, Samaha FF, Rickels MR. Niacin-induced impairments in glucose homeostasis are prevented by concomitant treatment with pioglitazone in metabolic syndrome patients. Diabetes 2009;58:A167.

\section{FATS 2001 \{published data only\}}

* Brown BG, Zhao XQ, Chait A, Fisher LD, Cheung MC, Morse JS, et al. Simvastatin and niacin, antioxidant vitamins, or the combination for the prevention of coronary disease. New England Journal of Medicine 2001;345:1583-92.

Maher VM, Brown BG, Marcovina SM, Hillger LA, Zhao XQ, Albers JJ. Effects of lowering elevated LDL cholesterol on the cardiovascular risk of lipoprotein(a). JAMA 1995;274:1771-4.

\section{Guyton 2000 \{published data only\}}

Guyton JR, Blazing MA, Hagar J, Kashyap ML, Knopp RH, McKenney JM, et al. Extended-release niacin vs gemfibrozil for the treatment of low levels of high-density lipoprotein cholesterol. Niaspan-Gemfibrozil Study Group. Archives of Internal Medicine 2000;160:1177-84.
HDL-Artherosclerosis Treatment Study 2004 \{published data only\}

Zhao XQ, Morse JS, Dowdy AA, Heise N, DeAngelis D, Frohlich J, et al. Safety and tolerability of simvastatin plus niacin in patients with coronary artery disease and low high-density lipoprotein cholesterol (The HDL Atherosclerosis Treatment Study). American Journal of Cardiology 2004;93:307-12.

\section{Hiatt 2010 \{published data only\}}

Hiatt WR, Hirsch AT, Creager MA, Rajagopalan S, Mohler ER, Ballantyne CM, et al. Effect of niacin ER/lovastatin on claudication symptoms in patients with peripheral artery disease. Vascular Medicine 2010;15:171-9.

\section{Hoeg 1984 \{published data only\}}

Hoeg JM, Maher MB, Bou E, Zech LA, Bailey KR, Gregg RE, et al. Normalization of plasma lipoprotein concentrations in patients with type II hyperlipoproteinemia by combined use of neomycin and niacin. Circulation 1984;70:1004-11.

\section{Hubacek 2010 \{published data only\}}

Hubacek J, Philpott AC, Sun YC, Lee V, Hilland D, Anderson TJ. Extended release niacin improves lipid profile but not endothelial function in patients with coronary artery disease on high dose statins. Journal of the American College of Cardiology 2010;55:A165.E1544.

\section{Illingworth 1994 \{published data only\}}

Illingworth DR, Stein EA, Mitchel YB, Dujovne CA, Frost PH, $\mathrm{Knopp} \mathrm{RH}$, et al. Comparative effects of lovastatin and niacin in primary hypercholesterolemia. A prospective trial. Archives of Internal Medicine 1994;154:1586-95.

\section{Insull 2004 \{published data only\}}

Insull W Jr, McGovern ME, Schrott H, Thompson P, Crouse JR, Zieve $F$, et al. Efficacy of extended-release niacin with lovastatin for hypercholesterolemia: assessing all reasonable doses with innovative surface graph analysis. Archives of Internal Medicine 2004;164:1121-7.

\section{Jungnickel 1997 \{published data only\}}

Jungnickel PW, Maloley PA, Vander Tuin EL, Peddicord TE, Campbell JR. Effect of two aspirin pretreatment regimens on niacin-induced cutaneous reactions. Journal of General Internal Medicine 1997;12:591-6.

\section{Kane 1990 \{published data only\}}

Kane JP, Malloy MJ, Ports TA, Phillips NR, Diehl JC, Havel RJ. Regression of coronary atherosclerosis during treatment of familial hypercholesterolemia with combined drug regimens. JAMA 1990;264:3007-12.

\section{Keenan 1990 \{published data only\}}

Keenan J, Bae CY, Fontaine P. A comparative clinicaltrial of low-dose sustained-release niacin (Enduracin) in hypercholesterolemia. Journal of the American Geriatrics Society 1990;38:A5.

\section{Klimov 1995 \{published data only\}}

Klimov AN, Konstantinov VO, Lipovetsky BM, Kuznetsov AS, Lozovsky VT, Trufanov VF, et al. "Essential" phospholipids 
versus nicotinic acid in the treatment of patients with type IIb hyperlipoproteinemia and ischemic heart disease. Cardiovascular Drugs and Therapeutics 1995;9:779-84.

\section{Knopp 1985 \{published data only\}}

Knopp RH, Ginsberg J, Albers JJ, Hoff C, Ogilvie JT, Warnick GR, et al. Contrasting effects of unmodified and time-release forms of niacin on lipoproteins in hyperlipidemic subjects: clues to mechanism of action of niacin. Metabolism 1985;34:642-50.

\section{Knopp 1998 \{published data only\}}

Knopp RH, Alagona P, Davidson M, Goldberg AC, Kafonek SD, Kashyap M, et al. Equivalent efficacy of a time-release form of niacin (Niaspan) given once-a-night versus plain niacin in the management of hyperlipidemia. Metabolism 1998;47:1097-104.

\section{Lamon-Fava 2008 \{published data only\}}

Lamon-Fava S, Diffenderfer MR, Barrett PH, Buchsbaum A, Nyaku M, Horvath KV, et al. Extended-release niacin alters the metabolism of plasma apolipoprotein (Apo) A-I and ApoBcontaining lipoproteins. Arteriosclerosis, Thrombosis, and Vascular Biology 2008;28:1672-8.

\section{Low 2007 \{published data only\}}

Menown IBA, Duffy M, Sharpe P, Dixon L, Flannery D, Khan M, et al. Randomised placebo-controlled trial of nicotinic acid in patients with coronary heart disease and low HDL-cholesterol despite 6 weeks statin therapy (LOW study). Journal of the American College of Cardiology 2007;49:366a.

\section{Morgan 1998 \{published data only\}}

Morgan JM, Capuzzi DM, Guyton JR. A new extendedrelease niacin (Niaspan): efficacy, tolerability, and safety in hypercholesterolemic patients. American Journal of Cardiology 1998;82:29U-34U; discussion 39U-41U.

\section{OCEANS 2008 \{published data only\}}

Brinton E, Thakkar R, Jiang P, Padley RJ. 2008 ATVB Oral Presentations. Arteriosclerosis, Thrombosis, and Vascular Biology 2008;28:e32-e149.

* Karas RH, Kashyap ML, Knopp RH, Keller LH, Bajorunas DR, Davidson MH. Long-term safety and efficacy of a combination of niacin ER and simvastatin in patients with dyslipidemia: the OCEANS study. American Journal of Cardiovascular Drugs 2008;8:69-81.

\section{Oster 1995 \{published data only\}}

Oster G, Borok GM, Menzin J, Heys JF, Epstein RS, Quinn V, et al. A randomised trial to assess effectiveness and cost in clinical practice: rationale and design of the Cholesterol Reduction Intervention Study (CRIS). Controlled Clinical Trials 1995;16:3-16.

\section{Pontiroli 1992 \{published data only\}}

Pontiroli AE, Fattor B, Pozza G, Pianezzola E, Strolin Benedetti M, Musatti L. Acipimox-induced facial skin flush: frequency, thermographic evaluation and relationship to plasma acipimox level. European Journal of Clininical Pharmacology 1992;43:145-8.

\section{Pradhan 2005 \{published data only\}}

Pradhan B, Neopane A, Karki S, Karki DB. Effectiveness of nicotinic acid and bezafibrate alone and in combination for reducing serum triglyceride level. Kathmandu University Medical Journal (KUMJ) 2005;3:411-4.

Sacks 1994 \{published data only\}

Sacks FM, Pasternak RC, Gibson CM, Rosner B, Stone PH. Effect on coronary atherosclerosis of decrease in plasma cholesterol concentrations in normocholesterolaemic patients. Harvard Atherosclerosis Reversibility Project (HARP) Group. Lancet 1994;344:1182-6.

\section{Safarova 2011 \{published data only\}}

Safarova M, Ezhov M, Trukhacheva E, Afanasieva O, Afanasieva M, Balakhonova T, Pokovsky S. Combined niacin and atorvastatin therapy for carotid atherosclerosis stabilization in middle aged men with CHD and elevated lipoprotein(a). Therapeutic Apheresis and Dialysis 2011;15:A1-A28.

Safarova M, Trukhacheva E, Ezhov M, Afanasieva O, Tripoten M, Pokrovsky S. 320 Pleiotropic effects of niacin therapy in addition to atorvastatin in coronary heart disease patients with elevated lipoprotein(a) levels. Atherosclerosis Supplements 2011;12:69.

* Safarova MS, Trukhacheva EP, Ezhov MV, Afanas'eva OI, Afanas'eva MI, Tripoten MI, et al. Pleiotropic effects of nicotinic acid therapy in men with coronary heart disease and elevated lipoprotein(a) levels. Kardiologiia 2011;51:9-16.

Trukhacheva E, Ezhov M, Titov V, Afanasieva O, Afanasieva M, Lyakishev A, et al. MS341 effect of niacin with atorvastatin on secretory phospholipase $\mathrm{A} 2$ in men with coronary heart disease and lipoprotein(a) excess. Atherosclerosis Supplements 2010;11:178.

\section{Sakai 2001 \{published data only\}}

Sakai T, Kamanna VS, Kashyap ML. Niacin, but not gemfibrozil, selectively increases LP-AI, a cardioprotective subfraction of $\mathrm{HDL}$, in patients with low HDL cholesterol. Arteriosclerosis, Thrombosis, and Vascular Biology 2001;21:1783-9.

\section{SEACOAST I 2008c \{published data only\}}

Ballantyne CM, Davidson MH, McKenney J, Keller LH, Bajorunas DR, Karas RH. Comparison of the safety and efficacy of a combination tablet of niacin ER and simvastatin vs simvastatin monotherapy in patients with increased non-HDL cholesterol (from the SEACOAST I study). American Journal of Cardiology 2008;101:1428-36.

\section{SEACOAST II 2008 \{published data only\}}

Ballantyne CM, Davidson MH, McKenney JM, Keller LH, Bajorunas DR, Karas RH. Comparison of the efficacy and safety of a combination tablet of niacin extended-release and simvastatin with simvastatin $80 \mathrm{mg}$ monotherapy: the SEACOAST II (high-dose) study. Journal of Clinal Lipidology 2008;2:79-90.

\section{Shah 2010 \{published data only\}}

Shah S, Ceska R, Gil-Extremera B, Paolini JF, Giezek H, Vandormael K, et al. Efficacy and safety of extended-release 
niacin/laropiprant plus statin vs. doubling the dose of statin in patients with primary hypercholesterolaemia or mixed dyslipidaemia. International Journal of Clinical Practice 2010;64:727-38.

\section{Smith 1963 \{published data only\}}

Smith CM, Hoffer A, Dantow M, McIntyre S. Nicotinic acid therapy in old age. The placebo effect and other factors in the collection of valid data. Journal of the American Geriatric Society 1963;11:580-5.

\section{Sorrentino 2010 \{published data only\}}

Sorrentino SA, Besler C, Rohrer L, Meyer M, Heinrich K, Bahlmann $\mathrm{FH}$, et al. Endothelial-vasoprotective effects of high-density lipoprotein are impaired in patients with type 2 diabetes mellitus but are improved after extended-release niacin therapy. Circulation 2010;121:110-22.

\section{Sposito 1999 \{published data only\}}

* Sposito AC, Caramelli B, Serrano CV Jr, Mansur AP, Ramires JA. Effect of niacin and etofibrate association on subjects with coronary artery disease and serum high-density lipoprotein cholesterol $<35 \mathrm{mg} / \mathrm{dl}$. American Journal of Cardiology 1999;83:98-100, A8.

Sposito AC, Mansur AP, Maranhao RC, Rodrigues-Sobrinho CR, Coelho OR, Ramires JA. Etofibrate but not controlled-release niacin decreases LDL cholesterol and lipoprotein (a) in type IIb dyslipidemic subjects. Brazilian Journal of Medical and Biological Research 2001;34:177-82.

\section{Superko 2009 \{published data only\}}

Superko HR, Garrett BC, King SB 3rd, Momary KM, Chronos NA, Wood PD. Effect of combination nicotinic acid and gemfibrozil treatment on intermediate density lipoprotein, and subclasses of low density lipoprotein and high density lipoprotein in patients with combined hyperlipidemia. American Journal of Cardiology 2009;103:387-92.

\section{Thoenes 2007 \{published data only\}}

Thoenes M, Oguchi A, Nagamia S, Vaccari CS, Hammoud R, Umpierrez GE, et al. The effects of extended-release niacin on carotid intimal media thickness, endothelial function and inflammatory markers in patients with the metabolic syndrome. International Journal of Clininical Practice 2007;61:1942-8.

\section{Tsalamandris 1994 \{published data only\}}

Tsalamandris C, Panagiotopoulos S, Sinha A, Cooper ME, Jerums $\mathrm{G}$. Complementary effects of pravastatin and nicotinic acid in the treatment of combined hyperlipidaemia in diabetic and non-diabetic patients. Journal of Cardiovascular Risk 1994;1:231-9.

\section{Zema 2000 \{published data only\}}

Zema MJ. Gemfibrozil, nicotinic acid and combination therapy in patients with isolated hypoalphalipoproteinemia: a randomised, open-label, crossover study. Journal of the American College of Cardiology 2000;35:640-6.

\section{References to ongoing studies \\ NCT00715273 \{published data only\}}

NCT00715273. Evaluate Carotid Artery Plaque Composition by Magnetic Resonance Imaging in People Receiving Cholesterol Medication (CPC). clinicaltrials.gov/ct2/show/record/ NCT00715273 (first received: July 11, 2008).

NCT02109614 \{published data only\}

NCT02109614. Early Aortic Valve Lipoprotein(a) Lowering Trial (EAVaLL). clinicaltrials.gov/ct2/show/NCT02109614 (first received: April 4, 2014).

\section{NCT02258074 \{published data only\}}

NCT02258074. The COMBINE Study: The CKD Optimal Management With BInders and NicotinamidE (COMBINE). clinicaltrials.gov/ct2/show/NCT02258074 (first received: July 28, 2014).

\section{NCT02416739 \{published data only\}}

NCT02416739. Anticancer Activity of Nicotinamide on Lung Cancer. clinicaltrials.gov/ct2/show/NCT02416739 (first received: April 3, 2015).

\section{NCT02558595 \{published data only\}}

NCT02558595. Pilot Study of Niacinamide in Polycystic Kidney Disease (NIAC-PKD2). clinicaltrials.gov/ct2/show/NCT02558595 (first received: September 21, 2015).

\section{Additional references}

\section{S 1994}

Scandinavian Simvastatin Survival Study Group. Randomised trial of cholesterol lowering in 4444 patients with coronary heart disease: the Scandinavian Simvastatin Survival Study (4S). Lancet 1994;344(8934):1383-9.

\section{ACC/AHA guideline 2013}

American College of Cardiology/American Heart Association Task Force on Practice Guidelines, Stone NJ, Robinson JG, Lichtenstein AH, Bairey Merz CN, Blum CB, Eckel RH, et al. 2013 $\mathrm{ACC} / \mathrm{AHA}$ guideline on the treatment of blood cholesterol to reduce atherosclerotic cardiovascular risk in adults: a report of the American College of Cardiology/American Heart Association Task Force on Practice Guidelines. Circulation 2014;66(129 (25 Supp( 2)):S1-45.

\section{Baigent 2005}

Baigent C, Keech A, Kearney P M, Blackwell L, Buck G, Pollicino $C$, et al. Efficacy and safety of cholesterol-lowering treatment: prospective meta-analysis of data from 90,056 participants in 14 randomised trials of statins. Lancet 2005;366(9493):1267-78.

\section{Ballantyne 2008a}

Ballantyne CM, Davidson MH, McKenney JM, Keller LH, Bajorunas DR, Karas RH. Comparison of the efficacy and safety of a combination tablet of niacin extended-release and simvastatin with simvastatin $80 \mathrm{mg}$ monotherapy: the SEACOAST II (high-dose) study. Journal of Clinical Lipidology 2008;2(2):79-90. 


\section{Ballantyne 2008b}

Ballantyne CM, Davidson MH, McKenney J, Keller LH, Bajorunas DR, Karas Richard H. Comparison of the safety and efficacy of a combination tablet of niacin ER and simvastatin vs simvastatin monotherapy in patients with increased non-HDL cholesterol (from the SEACOAST I study). The American Journal of Cardiology 2008;101(10):1428-36.

\section{Bays 2012a}

Bays HE, Shah A, Lin J, Sisk CM, Dong Q, Maccubbin D. Consistency of extended-release niacin/laropiprant effects on $\mathrm{Lp}(\mathrm{a}), \mathrm{ApoB}$, non-HDL-C, Apo A1, and ApoB/ApoA1 ratio across patient subgroups. American Journal of Cardiovascular Drugs 2012;12:197-206.

\section{Birjmohun 2005}

Birjmohun RS, Hutten BA, Kastelein JJ, Stroes ES. Efficacy and safety of high-density lipoprotein cholesterol-increasing compounds: a meta-analysis of randomised controlled trials. Journal of the American College of Cardiology 2005;45:185-97.

\section{Briel 2009}

Briel M, Ferreira-Gonzalez I, You JJ, Karanicolas PJ, Akl EA, Wu P, et al. Association between change in high density lipoprotein cholesterol and cardiovascular disease morbidity and mortality: systematic review and meta-regression analysis. BMJ (Clinical research ed.) 2009;338:b92.

\section{Brown 2006}

Brown BG, Stukovsky KH, Zhao X. Simultaneous low-density lipoprotein-C lowering and high-density lipoprotein-C elevation for optimum cardiovascular disease prevention with various drug classes, and their combinations: a meta-analysis of 23 randomised lipid trials. Current Opinion in Lipidology 2006;17(6):631-6.

\section{Bruckert 2010}

Bruckert E, Labreuche J, Amarenco P. Meta-analysis of the effect of nicotinic acid alone or in combination on cardiovascular events and atherosclerosis. Atherosclerosis 2010;210(2):353-61.

\section{Canner 1986}

Canner PL, Berge KG, Wenger NK, Stamler J, Friedman L, Prineas RJ, et al. Fifteen year mortality in Coronary Drug Project patients: long-term benefit with niacin. Journal of the American College of Cardiology 1986;8(6):1245-55.

\section{Cannon 2008}

Cannon CP, Giugliano RP, Blazing MA, Harrington RA, Peterson JL, McCrary Sisk C, et al. Rationale and design of IMPROVE-IT (IMProved Reduction of Outcomes: Vytorin Efficacy International Trial): comparison of ezetimbe/simvastatin versus simvastatin monotherapy on cardiovascular outcomes in patients with acute coronary syndromes. American Heart Journal 2008;156(5):826-32.

Charland 2010

Charland SL, Malone DC. Prediction of cardiovascular event risk reduction from lipid changes associated with high potency dyslipidemia therapy. Current Medical Research Opinion 2010;26:365-75.

\section{Deeks 2011}

Deeks JJ, Higgins JPT, Altman DG (editors). Chapter 9: Analysing data and undertaking meta-analyses. In: Higgins JPT, Green $\mathrm{S}$ (editors). Cochrane Handbook for Systematic Reviews of Interventions Version 5.1.0 (updated March 2011). The Cochrane Collaboration, 2011. Available from handbook.cochrane.org.

\section{Duggal 2010}

Duggal JK, Singh M, Attri N, Singh PP, Ahmed N, Pahwa S, et al. Effect of niacin therapy on cardiovascular outcomes in patients with coronary artery disease. Journal of Cardiovascular Pharmacology and Therapeutics 2010;15(2):158-66.

\section{Egger 1997}

Egger M, Davey Smith G, Schneider M, Minder C. Bias in metaanalysis detected by a simple, graphical test. BMJ (Clinical research ed.) 1997;315(7109):629-34.

\section{Furukawa 2007}

Furukawa TA, Watanabe N, Omori IM, Montori V M, Guyatt GH. Association between unreported outcomes and effect size estimates in Cochrane meta-analyses. JAMA 2007;297:468-70.

\section{Goldberg 2004}

Goldberg AC. A meta-analysis of randomised controlled studies on the effects of extended-release niacin in women. American Journal of Cardiology 2004;94:121-4.

\section{Goldie 2015}

Goldie C, Taylor AJ, Nguyen P, McCoy C, Zhao XQ, Preiss D. Niacin therapy and the risk of new-onset diabetes: a metaanalysis of randomised controlled trials. Heart 2015 [Epub ahead of print]:1.

\section{Gould 2007}

Gould AL, Davies GM, Alemao E, Yin DD, Cook JR. Cholesterol reduction yields clinical benefits: meta-analysis including recent trials. Clinal Therapeutics 2007;29:778-94.

\section{GRADEpro GDT 2014 [Computer program]}

GRADE Working Group, McMaster University. GRADEpro GDT. Version accessed September 2016. Hamilton (ON): GRADE Working Group, McMaster University, 2014.

\section{Graham 2007}

Graham I, Atar D, Borch-Johnsen K, Boysen G, Burell G, et al. European guidelines on cardiovascular disease prevention in clinical practice: full text. Fourth Joint Task Force of the European Society of Cardiology and other societies on cardiovascular disease prevention in clinical practice. European Journal of Cardiovascular Prevention and Rehabilitation 2007; Vol. 14 Suppl 2:S1-113.

\section{Grundy 2002}

Grundy SM, Vega GL, McGovern ME, Tulloch BR, Kendall DM, Fitz-Patrick D, et al. Efficacy, safety, and tolerability of oncedaily niacin for the treatment of dyslipidemia associated with type 2 diabetes: results of the assessment of diabetes control and evaluation of the efficacy of niaspan trial. Archives of Internal Medicine 2002;162(14):1568-76. 


\section{Guyton 2009a}

Guyton JR, Simmons PD. Flushing and other dermatologic adverse events associated with extended-release niacin therapy. Journal of Clinical Lipidolology 2009;3:101-8.

\section{HCSBG 2002}

Heart Protection Study Collaborative Group. MRC/BHF Heart Protection Study of cholesterol lowering with simvastatin in 20,536 high-risk individuals: a randomised placebo-controlled trial. Lancet 2002;360(9326):7-22.

\section{Higgins 2002}

Higgins JPT, Thompson SG. Quantifying heterogeneity in a meta-analysis. Statistics in Medicine 2002;21(11):1539-58.

\section{Higgins 2003}

Higgins JPT, Thompson SG, Deeks JJ, Altman DG. Measuring inconsistency in meta-analyses. BMJ (Clinical research ed.) 2003;327(7414):557-60.

\section{Higgins 2008}

Higgins JP, White IR, Wood AM. Imputation methods for missing outcome data in meta-analysis of clinical trials. Clinical Trials 2008;5:225-39.

\section{Higgins 2011a}

Higgins JPT, Altman DG, Sterne JAC (editors). Chapter 8: Assessing risk of bias in included studies. In: Higgins JPT, Green $\mathrm{S}$ (editors). Cochrane Handbook for Systematic Reviews of Interventions Version 5.1.0 (updated March 2011). The Cochrane Collaboration, 2011. Available from handbook.cochrane.org.

\section{Hooper 2001}

Hooper L, Summerbell CD, Higgins JPT, Thompson RL, Capps NE, Smith GD, et al. Dietary fat intake and prevention of cardiovascular disease: systematic review. BMJ (Clinical research ed.) 2001;322(7289):757-63.

\section{Hourcade-Potelleret 2015}

Hourcade-Potelleret F, Laporte S, Lehnert V, Delmar P, Benghozi R, Torriani U, et al. Clinical benefit from pharmacological elevation of high-density lipoprotein cholesterol: meta-regression analysis. Heart 2015;101:847-53.

\section{Insull 2009}

Insull W, Basile JN, Vo AN, Jiang P, Thakkar R, Padley RJ. Efficacy and safety of combination therapy with niacin extendedrelease and simvastatin versus atorvastatin in patients with dyslipidemia: The SUPREME Study. Journal of Clinical Lipidology 2009;3(2):109-18.

\section{Ip 2015}

Ip CK, Jin DM, Gao JJ, Meng Z, Meng J, Tan Z, et al. Effects of add-on lipid-modifying therapy on top of background statin treatment on major cardiovascular events: a meta-analysis of randomised controlled trials. International Journal of Cardiology 2015;191:138-48.

\section{JAMA 1975}

The Coronary Drug Project Research Group. Clofibrate and niacin in coronary heart disease. JAMA 1975;231(4):360-81.

\section{Jüni 1999}

Jüni P, Witschi A, Bloch R, Egger M. The hazards of scoring the quality of clinical trials for meta-analysis. JAMA 1999;282(11):1054-60

\section{Karas 2008}

Karas RH, Kashyap M, Knopp R, Keller L, Bajorunas D, Davidson M. Long-term safety and efficacy of a combination of niacin extended release and simvastatin in patients with dyslipidemia. American Journal of Cardiovascular Drugs 2008;8(2):69-81.

\section{Keene 2014}

Keene D, Price C, Shun-Shin MJ, Francis DP. Effect on cardiovascular risk of high density lipoprotein targeted drug treatments niacin, fibrates, and CETP inhibitors: meta-analysis of randomised controlled trials including 117,411 patients. BMJ 2014;349:g4379.

\section{Lefebvre 2011}

Lefebvre C, Manheimer E, Glanville J. Chapter 6: Searching for studies. In: Higgins JPT, Green S (editors). Cochrane Handbook for Systematic Reviews of Interventions Version 5.1.0 (updated March 2011). The Cochrane Collaboration, 2011. Available from handbook.cochrane.org. The Cochrane Collaboration.

\section{Lestra 2005}

Lestra JA, Kromhout D, Van der Schouw YT, Grobbee DE, Boshuizen HC, Van Staveren WA. Effect size estimates of lifestyle and dietary changes on all-cause mortality in coronary artery disease patients: a systematic review. Circulation 2005;112(6):924-34.

\section{McKenney 2004}

McKenney J. New perspectives on the use of niacin in the treatment of lipid disorders. Archives of internal Medicine 2004;164(7):697-705.

\section{McKenney 2010}

McKenney J, Bays H, Koren M, Ballantyne CM, Paolini JF, Mitchel Y, et al. Safety of extended-release niacin/laropiprant in patients with dyslipidemia. Journal of Clinal Lipidology 2010;4:105-112 e1.

\section{McKenney 2015}

McKenney J, Bays H, Gleim G, Mitchel Y, Kuznetsova O, Sapre A, et al. Safety and tolerability of extended-release niacinlaropiprant: pooled analyses for 11,310 patients in 12 controlled clinical trials. Journal of Clinal Lipidology 2015;9:313-25.

\section{Meyers 2003}

Meyers CD, Carr MC, Park S, Brunzell JD. Varying cost and free nicotinic acid content in over-the-counter niacin preparations for dyslipidemia. Annals of Internal Medicine 2003;139(12):996-1002.

\section{Michailov 2011}

Michailov GV, Davies GM, Krobot KJ. Cost-effectiveness of extended-release niacin/laropiprant added to a stable simvastatin dose in secondary prevention patients not at 
cholesterol goal in Germany. The European Journal of Health Economics 2011;13(3):365-74.

\section{Mills 2010}

Mills EJ, Wu P, Chong G, Ghement I, Singh S, Akl EA, et al. Efficacy and safety of statin treatment for cardiovascular disease: a network meta-analysis of 170255 patients from 76 randomised trials. QJM : Monthly Journal of the Association of Physicians 2010;104(2):109-24.

\section{Moore 2007}

Moore A, Phan Binh AP, Challender C, Williamson J, Marcovina S, Zhao X-Q. Effects of adding extended-release niacin and colesevelam to statin therapy on lipid levels in subjects with atherosclerotic disease. Journal of Clinical Lipidology 2007;1(6):620-5.

\section{Mozaffarian 2015}

American Heart Association Statistics Committee and Stroke Statistics Subcommittee, Mozaffarian D, Benjamin EJ, Go AS, Arnett DK, Blaha MJ, Cushman M, et al. Heart disease and stroke statistics--2015 update: a report from the American Heart Association. Circulation 2015;131(24):e18-e209.

\section{RevMan 2014 [Computer program]}

Nordic Cochrane Centre, The Cochrane Collaboration. Review Manager 5 (RevMan 5). Copenhagen: Nordic Cochrane Centre, The Cochrane Collaboration, 2014.

\section{Robinson 2009a}

Robinson J G, Wang S, Smith B J, Jacobson T A. Meta-analysis of the relationship between non-high-density lipoprotein cholesterol reduction and coronary heart disease risk. Journal of the American College of Cardiology 2009;53:316-22.

\section{Roze 2007}

Roze S, Ferrieres J, Bruckert E, Van Ganse E, Chapman M J, Liens D, et al. Cost-effectiveness of raising HDL cholesterol by adding prolonged-release nicotinic acid to statin therapy in the secondary prevention setting: a French perspective. International Journal of Clinical Practice 2007;61(11):1805-11.

\section{Schünemann 2011}

Schünemann HJ, Oxman AD, Vist GE, Higgins JPT, Deeks JJ, Glasziou P, et al. Chapter 12: Interpreting results and drawing conclusions. In: Higgins JPT, Green S (editors), Cochrane Handbook for Systematic Reviews of Interventions Version 5.1.0 (updated March 2011). The Cochrane Collaboration, 2011. Available from handbook.cochrane.org.

\section{Singh 2007}

Singh IM, Shishehbor MH, Ansell BJ. High-density lipoprotein as a therapeutic target: a systematic review. JAMA 2007;298(7):786-98.

\section{Sterne 2001}

Sterne JA, Egger M, Smith GD. Systematic reviews in health care: investigating and dealing with publication and other biases in meta-analysis. BMJ (Clinical research ed.) 2001;323(7304):101-5.

\section{Taylor 2004}

Taylor AJ, Sullenberger LE, Lee HJ, Lee JK, Grace KA. Arterial biology for the investigation of the treatment effects of reducing cholesterol (ARBITER) 2: a double-blind, placebocontrolled study of extended-release niacin on atherosclerosis progression in secondary prevention patients treated with statins. Circulation 2004;110(23):3512-7.

\section{Taylor 2009}

Taylor AJ, Villines TC, Stanek EJ, Devine PJ, Griffen L, Miller M, et al. Extended-release niacin or ezetimibe and carotid intima-media thickness. The New England Journal of Medicine 2009;361(22):2113-22

\section{Thom 2006}

Thom T, Haase N, Rosamond W, Howard VJ, Rumsfeld J, Manolio T, et al. Heart disease and stroke statistics--2006 update: a report from the American Heart Association Statistics Committee and Stroke Statistics Subcommittee. Circulation 2006;113(6):e85-151.

\section{Thompson 1999}

Thompson SG, Sharp SJ. Explaining heterogeneity in metaanalysis: a comparison of methods. Statistics in Medicine 1999;18(20):2693-708.

\section{Vaccari 2007}

Vaccari CS, Nagamia S, Thoenes M, Oguchi A, Hammoud R, Khan BV. Efficacy of controlled-release niacin in treatment of metabolic syndrome: correlation to surrogate markers of atherosclerosis, vascular reactivity, and inflammation. Journal of Clinical Lipidology 2007;1(6):605-13.

\section{Verdoia 2015}

Verdoia M, Schaffer A, Suryapranata H, De Luca G. Effects of HDL-modifiers on cardiovascular outcomes: a meta-analysis of randomised trials. Nutrition, Metabolism, and Cardiovascular Diseases : NMCD 2015;25:9-23.

\section{Walter 2017}

Walter SD, Han H, Briel M, Guyatt G. Quantifying the bias in the estimated treatment effect in randomized trials having interim analyses and a rule for early stopping for futility. Statistics in Medicine 2017;36(9):1506-18.

\section{Zhao 2004}

Zhao X-Q, Morse JS, Dowdy AA, Heise N, DeAngelis D, Frohlich J, et al. Safety and tolerability of simvastatin plus niacin in patients with coronary artery disease and low high-density lipoprotein cholesterol (The HDL Atherosclerosis Treatment Study). The American Journal of Cardiology 2004;93(3):307-12.

* Indicates the major publication for the study 
CHARACTERISTICS OF STUDIES

Characteristics of included studies [ordered by study ID]

ADMIT 2000

Design: parallel-group, factorial (niacin x antioxidant x warfarin), pilot trial
Recruitment: 468 participants from $1993-1994$ in 6 study centres in the USA
Setting: primary, secondary, and tertiary care
Funding: Bristol Myers Squibb supplied pravastatin, Hoffman LaRoche supplied antioxidants, Merck
Dupont supplied warfarin, and Upsher Smith supplied niacin

Participants

Inclusion criteria: 30 years or older, ankle-brachial index $<0.85$, documented surgery or angioplasty for peripheral arterial disease, average LDL-C level $<190 \mathrm{mg} / \mathrm{dL}$. Able to tolerate niacin and warfarin (see run-in)

Exclusion criteria: baseline fasting TG $500 \mathrm{mg} / \mathrm{dL}$ or averaged $400 \mathrm{mg} / \mathrm{dL}$; overt complications of peripheral arterial disease, cardiovascular events within 6 months, unstable angina, history of congestive heart failure NYHA class III or IV, atrial fibrillation, poorly controlled diabetes, uncontrolled hypertension, active peptic ulcer, history of bleeding, history of repeated venous thromboembolic disease, cancer within last 10 years, renal insufficiency, liver disease, thrombocytopenia, anaemia, history of gout, history of myositis/rhabdomyolysis, hypothyroidism, therapy with warfarin, heparin or ticlopidine, lipid-lowering drug, cyclosporine, corticosteroids, alcohol consumption $>14$ drinks/week, Women with child-bearing potential, contraindications to study medications, non-compliance during run-in

Run-in/enrichment: 3-4 months, niacin $1 \mathrm{mg} /$ day (eligibility criteria), warfarin $1 \mathrm{mg} /$ day, and placebos

\section{Baseline characteristics}

Age: 65 years, SD 9

Men: $81 \%$ (379/468)

Diabetes: 24\% (110/468)

Current smoker: 39\% (183/468)

Prior MI/established CHD: 40\% (187)

Hypertension: 61\% (287/486)

Statin therapy: 100\%

Arm 2: Placebo (randomised $=231$, complete cases $=209$ )

Duration of treatment: 11 months, "follow-up at 48 weeks was approximately $85 \%$ in each treatment group."

Measure to prevent flushing/unblinding due to flushing: $15 \%$ of placebo tables contained low dose niacin (50 mg, no lipid effect expected). Participants therefore experienced intermittent flushing in order to minimise unmasking of niacin therapy

Background therapy: All participants received open-label pravastatin titrated to achieve LDL-C $<130$ $\mathrm{mg} / \mathrm{dL}$. Factorial trial: participants were randomly assigned either to active or placebo antioxidant (beta-carotene, vitamin $\mathrm{E}$, and vitamin $\mathrm{C}$ antioxidants). Participants were randomly assigned to active or placebo warfarin. All participants were encouraged to stop smoking and/or maintain abstinence from smoking. All participants received aspirin 
ADMIT 2000 (Continued)

mination of the feasibility of recruiting women and minorities, asymptomatic people with peripheral arterial disease, and people without overt coronary vascular disease; (3) assessment of the ability to maintain therapy masking; (4) success in treatment during follow-up measured in terms of the proportion of values within target range at the 3-month follow-up for biochemical parameters (LDL-C, $70 \mathrm{mg}$ / $\mathrm{dL}-130 \mathrm{mg} / \mathrm{dL}$; HDL-C, increased $20 \%$ to $25 \%$; international normalised ratio, 1.5 to 2.0 ; additionally, antioxidant levels were obtained to measure the effect of the antioxidant therapy); (5) safety maintained by close monitoring of side effects, alanine aminotransferase, haemoglobin A1c, and international normalised ratio; and (6) adherence to therapy measured by pill count and proportion of scheduled follow-up visits completed and by dropout rate

Secondary outcomes: Not reported

Notes Compliance: based on pill count, $90 \%$ in the niacin group and $87 \%$ in the placebo group

Registration: Not reported

Not completed as planned: Original sample size was 600

\section{Risk of bias}

\begin{tabular}{|c|c|c|}
\hline Bias & Authors' judgement & Support for judgement \\
\hline $\begin{array}{l}\text { Random sequence genera- } \\
\text { tion (selection bias) }\end{array}$ & Low risk & $\begin{array}{l}\text { Not explicitly reported but likely computer-generated. "Randomization assign- } \\
\text { ments at each clinical centre were made in blocks of random size where the } \\
\text { block size was a multiple of } 8 \text { " }\end{array}$ \\
\hline $\begin{array}{l}\text { Allocation concealment } \\
\text { (selection bias) }\end{array}$ & Unclear risk & Not reported \\
\hline $\begin{array}{l}\text { Blinding of participants } \\
\text { and personnel (perfor- } \\
\text { mance bias) } \\
\text { All outcomes }\end{array}$ & Low risk & $\begin{array}{l}\text { "Double blind", placebo-controlled, specific measures to blind investigators } \\
\text { and prevent unblinding of participants, "assessment of the ability to maintain } \\
\text { therapy masking" mentioned as outcome }\end{array}$ \\
\hline $\begin{array}{l}\text { Blinding of outcome as- } \\
\text { sessment (detection bias) } \\
\text { All outcomes }\end{array}$ & Unclear risk & Not reported, low for participant-reported outcomes \\
\hline $\begin{array}{l}\text { Incomplete outcome data } \\
\text { (attrition bias) } \\
\text { All outcomes }\end{array}$ & High risk & $\begin{array}{l}\text { Outcome mortality not reported. Outcome "discontinuation of treatment due } \\
\text { to side effects": proportion of missing data } 10 \% \text { in both groups; events/miss- } \\
\text { ing: } 19 / 43 \text { in intervention, } 9 / 31 \text { in control }\end{array}$ \\
\hline $\begin{array}{l}\text { Selective reporting (re- } \\
\text { porting bias) }\end{array}$ & Unclear risk & Only retrospectively published protocol available \\
\hline Other bias & Low risk & None \\
\hline
\end{tabular}

\section{AIM-HIGH 2011}

Design: 2 parallel-groups
Recruitment: 3414 participants from 2006-2010 at 92 centres in USA and Canada
Setting: Not reported
Funding: National Heart, Lung, and Blood Institute, unrestricted grant from Abbott Laboratories. Ab-
bott Laboratories donated the extended-release niacin, the matching placebo, and ezetimibe; Merck


Participants

Inclusion criteria: 45 years or older, established cardiovascular disease (documented stable CHD, cerebrovascular or carotid disease, or peripheral arterial disease), low baseline levels of HDL cholesterol ( $<40 \mathrm{mg} / \mathrm{dL}$ for men; $<50 \mathrm{mg} / \mathrm{dL}$ for women), elevated triglyceride levels ( $150 \mathrm{mg} / \mathrm{dL}-400 \mathrm{mg} / \mathrm{dL}$ ), LDL-C levels lower than $180 \mathrm{mg} / \mathrm{dL}$.

Exclusion criteria: hospitalised for an acute coronary syndrome or had undergone a planned revascularisation within 4 weeks, stroke within 8 weeks, fasting glucose $>180 \mathrm{mg} / \mathrm{dL}$ or haemoglobin A1C > $9.0 \%$, BP $>200 / 100 \mathrm{~mm} \mathrm{Hg}$ unresponsive to medical therapy, active peptic ulcer, active liver disease, recent history of acute gout, chronic renal insufficiency, risk of pregnancy, significant comorbidity likely to cause death in the 3- to 5-year follow-up, AIDS/active HIV infection, history of substance abuse within 5 years

Run-in/enrichment: open-label simvastatin $40 \mathrm{mg} /$ day + extended-release niacin increasing to 2000 $\mathrm{mg} /$ day. Run-in phase could be extended to 8 weeks to demonstrate tolerance of at least $1500 \mathrm{mg} / \mathrm{day}$ of niacin

\section{Baseline characteristics}

Age: Mean 63.7, SD 8.7

Men. $85 \%$

Diabetes: $33 \%$

Current smoker: not reported

Prior MI/established CHD: 56\%

Hypertension: $71 \%$

Statin therapy: $94 \%$

Interventions

Arm 1: niacin extended-release at a dose of $1500 \mathrm{mg} /$ day-2000 mg/day plus simvastatin $40 \mathrm{mg} /$ day. For those limited to a niacin dose of $1500 \mathrm{mg} /$ day during the run-in, there was a subsequent attempt to increase dosage to $2000 \mathrm{mg} /$ day over the first year (randomised $=1718$, complete cases $=1693$ )

Arm 2: simvastatin + a matching placebo (randomised $=1696$, complete cases $=1672$ )

Duration of treatment: mean 36 months

Measure to prevent flushing/unblinding due to flushing: medication at bedtime with a low-fat snack and, if allowed by private physician, taking $325 \mathrm{mg}$ aspirin up to $30 \mathrm{~min}$ before taking blinded study medication, avoid hot or spicy food/drink around the time of dosing. Each placebo tablet included a sub-therapeutic dose of immediate-release niacin $50 \mathrm{mg}$.

Background therapy: simvastatin $40 \mathrm{mg} /$ day titrated to LDL-C level in the range of $40 \mathrm{mg} / \mathrm{dL}-80 \mathrm{mg} \mathrm{dL}$. Participants in both groups could receive ezetimibe, at a dose of $10 \mathrm{mg} /$ day, to achieve the target LDLClevel

Outcomes

Primary outcome: composite, first occurrence of $\mathrm{CHD}$ death, non-fatal MI, ischaemic stroke, hospitalisation for acute coronary syndrome, or symptom-driven coronary or cerebral revascularisation

Secondary outcomes: composite end points of (1) CHD death, non-fatal MI, ischaemic stroke, or highrisk acute coronary syndrome; or (2) CHD death, non-fatal MI, or ischaemic stroke; or (3) any cardiovascular death

Tertiary outcomes: all-cause death, composite of all-cause death, admission for acute coronary syndrome, ischaemic stroke or any arterial revascularisation, and the individual components of the end points 
AIM-HIGH 2011 (Continued)

Notes
Compliance: the study drug was discontinued in $25.4 \%$ of the participants in the niacin group and in $20.1 \%$ of the participants in the placebo group. The overall rate of adherence among the participants who continued treatment was at least $75 \%$

\section{Registration: NCT00120289}

Not completed as planned: "As a result of the much lower than expected overall event rate, the primary endpoint was redefined." In addition, the follow-up was stopped for futility and harm: "the data and safety monitoring board recommended that the blinded intervention be stopped because the boundary for lack of efficacy had been crossed and an unexpected higher rate of ischaemic stroke had been observed among patients who were being treated with niacin"

\section{Risk of bias}

\begin{tabular}{|c|c|c|}
\hline Bias & Authors' judgement & Support for judgement \\
\hline $\begin{array}{l}\text { Random sequence genera- } \\
\text { tion (selection bias) }\end{array}$ & Low risk & $\begin{array}{l}\text { Not explicitly reported but likely computer-generated: "Randomization was } \\
\text { performed with the use of a secure Internet application" }\end{array}$ \\
\hline $\begin{array}{l}\text { Allocation concealment } \\
\text { (selection bias) }\end{array}$ & Low risk & "Randomization was performed with the use of a secure Internet application" \\
\hline $\begin{array}{l}\text { Blinding of participants } \\
\text { and personnel (perfor- } \\
\text { mance bias) } \\
\text { All outcomes }\end{array}$ & Low risk & "Blinded treatment to patients and study personnel" \\
\hline $\begin{array}{l}\text { Blinding of outcome as- } \\
\text { sessment (detection bias) } \\
\text { All outcomes }\end{array}$ & Low risk & $\begin{array}{l}\text { "A clinical events committee reviewed suspected primary end points (includ- } \\
\text { ing silent myocardial infarction) with supporting documentation that did not } \\
\text { reveal the treatment assignments" }\end{array}$ \\
\hline $\begin{array}{l}\text { Incomplete outcome data } \\
\text { (attrition bias) } \\
\text { All outcomes }\end{array}$ & Low risk & $\begin{array}{l}\text { Proportion of missing data: } 1.5 \% \text { in both groups; event/missing: } 96 / 25 \text { in inter- } \\
\text { vention and } 82 / 24 \text { in control }\end{array}$ \\
\hline $\begin{array}{l}\text { Selective reporting (re- } \\
\text { porting bias) }\end{array}$ & Low risk & $\begin{array}{l}\text { All outcomes pre-specified in the prospectively published trial registry record } \\
\text { were subsequently reported }\end{array}$ \\
\hline Other bias & Low risk & None \\
\hline
\end{tabular}

\section{ALPINE-SVG 2015}

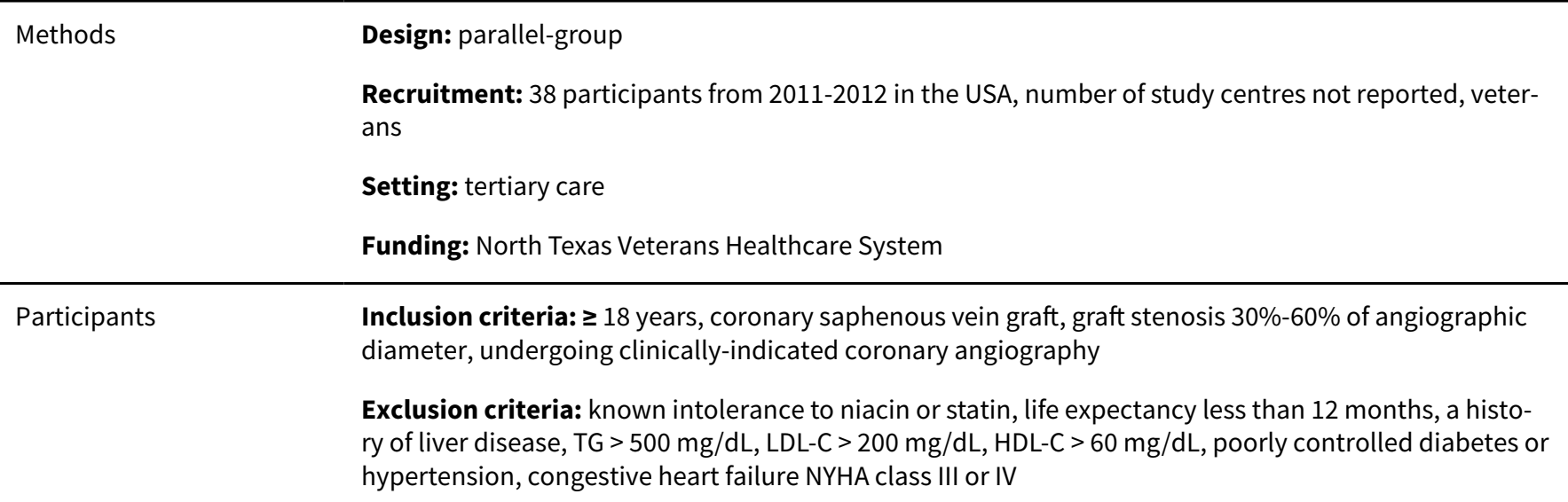


ALPINE-SVG 2015 (Continued)

Run-in/enrichment: 4 weeks

\section{Baseline characteristics}

Age: 65 years, SD 6

Men: not reported

Diabetes: 63\%

Current smoker: not reported

Prior MI/established CHD: $67 \%$

Hypertension: 95\%

Statin therapy: $100 \%$

Interventions

Arm 1: extended-release niacin (Niaspan), $1500 \mathrm{mg} /$ day-2000 mg/day (randomised = 19, complete cases $=19)$

Arm 2: placebo $($ randomised $=19$, complete cases $=19)$

Duration of treatment: 12 months

Measure to prevent flushing/unblinding due to flushing: 4 week run-in, matching placebo contained $50 \mathrm{mg}$ of crystalline niacin that causes flushing but has no effect on lipid levels

Background therapy: all participants received statin drugs

Primary outcome: change in percent atheroma volume at intravascular ultrasonography
Secondary outcomes: a number of radiographic measures for Intermediate saphenous vein graft le-
sions, exercise capacity and ischaemia assessed by exercise stress testing, carotid intima-media thick-
ness, reactive hyperemia index, endothelial progenitor cells-colony forming units $/ \mathrm{mL}$ of peripheral
blood, major adverse cardiac events

Notes

Compliance: $89 \%$ in the intervention, and $95 \%$ in the control arm

Registration: NCT01221402

ALPINE-SVG was stopped early after publication of AIM-HIGH 2011 and HPS2-THRIVE 2014 (planned: 138 participants, enrolled: 38 participants)

\section{Risk of bias}

\begin{tabular}{lll}
\hline Bias & Authors' judgement & Support for judgement \\
\hline $\begin{array}{l}\text { Random sequence genera- } \\
\text { tion (selection bias) }\end{array}$ & Unclear risk & Not reported \\
\hline $\begin{array}{l}\text { Allocation concealment } \\
\text { (selection bias) }\end{array}$ & Unclear risk & Not reported \\
\hline $\begin{array}{l}\text { Blinding of participants } \\
\text { and personnel (perfor- } \\
\text { mance bias) } \\
\text { All outcomes }\end{array}$ & Low risk & "Double Blind (Subject, Caregiver, Investigator, Outcomes Assessor)" \\
\hline
\end{tabular}

Blinding of outcome as- Low risk $\quad$ "Double Blind (Subject, Caregiver, Investigator, Outcomes Assessor)"
sessment (detection bias)
All outcomes


ALPINE-SVG 2015 (Continued)

Incomplete outcome data Low risk_ "All patients entering the trial prior to early termination of enrolment complet(attrition bias) ed the trial"

All outcomes

$\begin{array}{ll}\begin{array}{l}\text { Selective reporting (re- } \\ \text { porting bias) }\end{array} & \text { Low risk }\end{array}$

\begin{tabular}{ll}
\hline Other bias $\quad$ Low risk $\quad$ None \\
\hline
\end{tabular}

Design: Parallel-group
Recruitment: 167 participants from 2001-2003 at 1 study centre in the USA
Setting: tertiary care military medical centre
Funding: partial funding for this study was provided by Kos Pharmaceuticals in the form of an unre-
stricted research grant administered by the Henry M. Jackson Foundation for the Advancement of Mili-
tary Medicine

Participants

Inclusion criteria: 30 years or older, coronary vascular disease, currently treated with a statin, LDL-C < $130 \mathrm{mg} / \mathrm{dL}$ and $\mathrm{HDL}-\mathrm{C}<45 \mathrm{mg} / \mathrm{dL}$

Exclusion criteria: known intolerance to niacin, a history of liver disease, or abnormal liver associated enzymes

Run-in/enrichment: not reported

\section{Baseline characteristics}

Age: 67 years, SD 10

Men: $91 \%$

Diabetes: $28 \%$

Current smoker: $10 \%$

Prior MI/established CHD: 50\%

Hypertension: $75 \%$

Statin therapy: $100 \%$

Arm 1: extended-release niacin (Niaspan), dose increased from $500 \mathrm{mg}-1000 \mathrm{mg}$ within 30 days (randomised $=87$, complete cases $=78$ )

Arm 2: placebo (randomised $=80$, complete cases $=71$ )

Duration of treatment: maximum 12 months

Measure to prevent flushing/unblinding due to flushing: medication taken at night, taken with the participant's usual daily dose of aspirin

Background therapy: all participants received statin drugs 
ARBITER-2 2004 (Continued)

Secondary outcomes: changes in serum lipid concentrations, liver-associated enzyme elevations, composite of clinical cardiovascular events including any hospitalisation for an acute coronary syndrome, stroke, an arterial revascularisation procedure, or sudden cardiac death

Notes

Compliance: adherence to study medication based on pill counts at $90,180,270$, and 365 days ranged from $90.3 \%$ to $94.5 \%$ and was not statistically different between the placebo and niacin groups.

Registration: not reported

\section{Risk of bias}

\begin{tabular}{|c|c|c|}
\hline Bias & Authors' judgement & Support for judgement \\
\hline $\begin{array}{l}\text { Random sequence genera- } \\
\text { tion (selection bias) }\end{array}$ & Low risk & "Computer-generated sequence" \\
\hline $\begin{array}{l}\text { Allocation concealment } \\
\text { (selection bias) }\end{array}$ & Low risk & "Central research pharmacy to dispense the study medication" \\
\hline $\begin{array}{l}\text { Blinding of participants } \\
\text { and personnel (perfor- } \\
\text { mance bias) } \\
\text { All outcomes }\end{array}$ & Low risk & $\begin{array}{l}\text { "Double blind", "Only the research pharmacist was aware of the study drug as- } \\
\text { signment." }\end{array}$ \\
\hline $\begin{array}{l}\text { Blinding of outcome as- } \\
\text { sessment (detection bias) } \\
\text { All outcomes }\end{array}$ & Low risk & "Only the research pharmacist was aware of the study drug assignment." \\
\hline $\begin{array}{l}\text { Incomplete outcome data } \\
\text { (attrition bias) } \\
\text { All outcomes }\end{array}$ & High risk & $\begin{array}{l}\text { Proportion of missing data: } 10 \% \text { in intervention and } 11 \% \text { in control; event/ } \\
\text { missing: } 1 / 9 \text { in intervention and } 2 / 9 \text { in control }\end{array}$ \\
\hline $\begin{array}{l}\text { Selective reporting (re- } \\
\text { porting bias) }\end{array}$ & Unclear risk & No protocol published, not registered \\
\hline Other bias & Low risk & None \\
\hline
\end{tabular}

\section{Capuzzi 2003}

Design: parallel-group
Recruitment: 270 participants in 39 centres in the USA (time not reported)
Setting: tertiary care
Funding: AstraZeneca Pharmaceuticals, LP, Wilmington, DE. The primary study site at Thomas Jeffer-
son University also received support from the Sidney Kimmel Laboratory for Preventive Cardiology
Inclusion criteria: aged $\geq 18$ years, combined dyslipidaemia, fasting levels of cholesterol $\geq 200 \mathrm{mg} / \mathrm{dL}$,
TG $\geq 200 \mathrm{mg} / \mathrm{dL}$ and $\leq 800 \mathrm{mg} / \mathrm{dL}$, apolipoprotein B $\geq 110 \mathrm{mg} / \mathrm{dL}$, and HDL-C $<45 \mathrm{mg} / \mathrm{dL}$
Participants
ications that posed potential study concerns, women at risk of pregnancy, uncontrolled hypertension,
hypothyroidism; creatine kinase $>3$ times the upper limit of normal; serum creatinine concentrations
$>1.8 \mathrm{mg} / \mathrm{dL}$, use of concomitant medications known to affect serum lipid levels or present safety con-
cerns


Run-in/enrichment: 6-week, instruction to discontinue all lipid-modifying medications, dietary supplements, and food additives, and to adhere to the American Heart Association Step I diet

\section{Baseline characteristics}

Age: 56.8 , SD 10.5

Men: $74 \%$

Diabetes: $15 \%$

Current smoker: not reported

Prior MI/established CHD: 0\%

Hypertension: not reported (uncontrolled hypertension was an exclusion criterion)

Statin therapy: $100 \%$ (part of interventions)

Interventions

Arm 1: rosuvastatin $40 \mathrm{mg}$ monotherapy: rosuvastatin $10 \mathrm{mg}$ for 12 weeks, $20 \mathrm{mg}$ for 6 weeks, and 40 $\mathrm{mg}$ for 6 weeks (randomised $=72$, complete cases $=60$ )

Arm 2: niacin extended-release $0.5 \mathrm{~g}$ for 4 weeks, $1.0 \mathrm{~g}$ for 8 weeks, $1.5 \mathrm{~g}$ for 6 weeks, and $2.0 \mathrm{~g}$ for 6 weeks

Arm 3: rosuvastatin $40 \mathrm{mg} /$ niacin extended-release $1 \mathrm{~g}$ : niacin $0.5 \mathrm{~g}$ for 4 weeks, $1.0 \mathrm{~g}$ for 2 weeks, $1.0 \mathrm{~g}$ plus rosuvastatin $10 \mathrm{mg}$ for 6 weeks, $1.0 \mathrm{~g}$ plus rosuvastatin $20 \mathrm{mg}$ for 6 weeks, and $1.0 \mathrm{~g}$ plus rosuvastatin $40 \mathrm{mg}$ for 6 weeks (randomised $=46$, complete cases $=43$ )

Arm 4: rosuvastatin 10-mg/niacin extended-release 2-g group: niacin $0.5 \mathrm{~g}$ for 4 weeks, $1.0 \mathrm{~g}$ for 2 weeks, $1.0 \mathrm{~g}$ plus rosuvastatin $10 \mathrm{mg}$ for 6 weeks, $1.5 \mathrm{~g}$ plus rosuvastatin

We included the comparison arm 1 vs. arm 3

Duration of treatment: maximum 12 months

Measure to prevent flushing/unblinding due to flushing: extended-release, niacin taken with water at bedtime after a low-fat snack

Background therapy: not reported

$\begin{array}{ll}\text { Outcomes } & \text { Primary outcome: fasting plasma LDL-C levels } \\ & \text { Secondary outcomes: Fasting plasma levels of TC, non-HDL cholesterol, TG, VLDL cholesterol, } \\ \text { apolipoprotein B, HDL cholesterol, apolipoprotein A-1, and lipoprotein(a) (Lp[a]) }\end{array}$

Notes Compliance: intervention: $67 \%$, control: $47 \%$

Registration: not reported

\section{Risk of bias}

\begin{tabular}{lll}
\hline Bias & Authors' judgement & Support for judgement \\
\hline $\begin{array}{l}\text { Random sequence genera- } \\
\text { tion (selection bias) }\end{array}$ & Unclear risk & Not reported \\
\hline $\begin{array}{l}\text { Allocation concealment } \\
\text { (selection bias) }\end{array}$ & Unclear risk & Not reported \\
\hline $\begin{array}{l}\text { Blinding of participants } \\
\text { and personnel (perfor- } \\
\text { mance bias) }\end{array}$ & High risk & "Open-label"; low risk of bias for mortality, high for subjective outcomes \\
\hline
\end{tabular}


Capuzzi 2003 (Continued)

All outcomes

Blinding of outcome as- $\quad$ High risk $\quad$ "Open-label"
sessment (detection bias)
All outcomes

All outcomes

\begin{tabular}{|c|c|c|}
\hline $\begin{array}{l}\text { Incomplete outcome data } \\
\text { (attrition bias) } \\
\text { All outcomes }\end{array}$ & Low risk & $\begin{array}{l}\text { Outcome overall mortality not reported. Outcome discontinuation of treat- } \\
\text { ment due to side effects: proportion of missing data: } 7 \% \text { in intervention and } \\
4 \% \text { in control; events/missing: } 7 / 5 \text { in intervention, } 1 / 2 \text { in control }\end{array}$ \\
\hline
\end{tabular}

All outcomes

introl; events/missing: $7 / 5$ in intervention, $1 / 2$ in control

Selective reporting (re- Unclear risk No protocol published, not registered

porting bias)

\begin{tabular}{lll}
\hline Other bias $\quad$ Low risk & None \\
\hline
\end{tabular}

\section{Carotid IMT 2008}

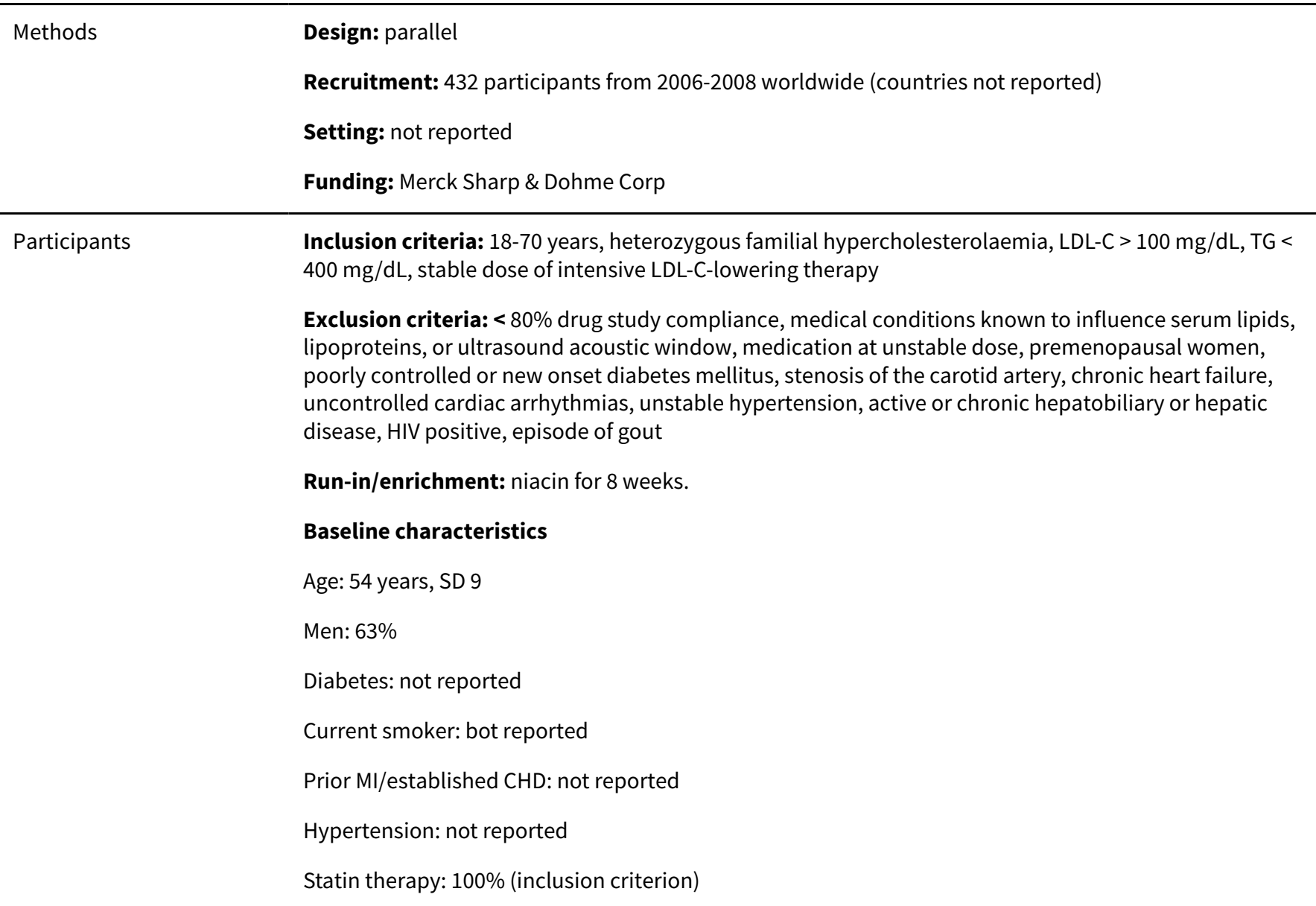

Arm 1: niacin 2000 mg/day + laropiprant (dose not reported) (randomised = 214, complete cases $=180)$

Arm 2: placebo $($ randomised $=218$, complete cases $=204)$

Duration of treatment: maximum 96 weeks

Measure to prevent flushing/unblinding due to flushing: laropiprant 
Carotid IMT 2008 (Continued)

Background therapy: not reported

Outcomes Primary outcome: carotid intima media thickness

Secondary outcomes: lipid profile

\begin{tabular}{ll}
\hline Notes & Compliance: not reported \\
& Registration: NCT00384293 \\
Not completed as planned: no reason provided
\end{tabular}

\title{
Risk of bias
}

\begin{tabular}{lll}
\hline Bias & Authors' judgement & Support for judgement \\
\hline $\begin{array}{l}\text { Random sequence genera- } \\
\text { tion (selection bias) }\end{array}$ & Unclear risk & Not reported \\
\hline $\begin{array}{l}\text { Allocation concealment } \\
\text { (selection bias) }\end{array}$ & Unclear risk & Not reported \\
\hline
\end{tabular}

Blinding of participants Low risk "Double-blind"
and personnel (perfor-
mance bias)
All outcomes

\begin{tabular}{lll}
\hline $\begin{array}{l}\text { Blinding of outcome as- } \\
\text { sessment (detection bias) } \\
\text { All outcomes }\end{array}$ & Unclear risk & Not reported, low risk of bias for participant-reported outcomes \\
\hline $\begin{array}{l}\text { Incomplete outcome data } \\
\text { (attrition bias) }\end{array}$ & High risk & $\begin{array}{l}\text { Outcome overall mortality not reported. Outcome fatal or non-fatal Ml: pro- } \\
\text { portion of missing data: } 16 \% \text { in intervention and } 6 \% \text { in control; events/missing } \\
\text { ratio: } 0 / 34 \text { in intervention, } 1 / 14 \text { control }\end{array}$ \\
\hline
\end{tabular}

Selective reporting (re- Unclear risk No protocol published, clinical outcomes not specified in registry
porting bias)

Other bias Low risk None

Setting: not reported

Funding: National Heart and Lung Institute

\begin{abstract}
Participants
Inclusion criteria: men; aged 30-64 years; proved previous MI (class I or II of the functional classification of the NYHA and free from a specified list of diseases and conditions), at least 3 months beyond their most recent MI, free of evidence of recent worsening of their coronary disease or of other major illnesses
\end{abstract}

Exclusion criteria: not reported

Run-in/enrichment: 2-month control period 
CDP 1975 (Continued)

\section{Baseline characteristics}

Age: $\geq 55$ years

Men: $44 \%$

Diabetes: $5 \%$ oral hypoglycaemic drug

Current smoker: $38 \%$

Prior MI/established CHD: $100 \%$

Hypertension: 52\%

Statin therapy: $0 \%$ (not available at the time)

Arm 1: conjugated estrogens, $2.5 \mathrm{mg} /$ day

Arm 2: conjugated estrogens, $5.0 \mathrm{mg} /$ day

Arm 3: clofibrate, $1.8 \mathrm{~g} /$ day

Arm 4: dextrothyroxine sodium, $6.0 \mathrm{mg} /$ day

Arm 5: niacin, 3.0 g/day (randomised = 1119, complete cases $=1116$ )

Arm 6: placebo $($ randomised $=2798$, complete cases $=2797)$

We included the comparison arm 5 vs arm 6

Duration of treatment: maximum 96 weeks

Measure to prevent flushing/unblinding due to flushing: not reported

Background therapy: not reported

\begin{tabular}{|c|c|c|}
\hline Outcomes & \multicolumn{2}{|c|}{$\begin{array}{l}\text { Primary outcome: overall mortality } \\
\text { Secondary outcomes: other major end points included cause-specific mortality, particularly coronary } \\
\text { mortality and sudden death, and non-fatal cardiovascular events such as recurrent MI, acute coronary } \\
\text { insufficiency, development of angina pectoris, congestive heart failure, stroke, pulmonary embolism, } \\
\text { and arrhythmias }\end{array}$} \\
\hline Notes & \multicolumn{2}{|c|}{$\begin{array}{l}\text { Compliance: median compliance } 85 \% \text { over } 5 \text { years } \\
\text { Registration: NCT00000482 }\end{array}$} \\
\hline \multicolumn{3}{|l|}{ Risk of bias } \\
\hline Bias & Authors' judgement & Support for judgement \\
\hline $\begin{array}{l}\text { Random sequence genera- } \\
\text { tion (selection bias) }\end{array}$ & Unclear risk & Not reported \\
\hline $\begin{array}{l}\text { Allocation concealment } \\
\text { (selection bias) }\end{array}$ & Unclear risk & Not reported \\
\hline $\begin{array}{l}\text { Blinding of participants } \\
\text { and personnel (perfor- } \\
\text { mance bias) } \\
\text { All outcomes }\end{array}$ & Low risk & $\begin{array}{l}\text { Neither the participant nor the clinic staff was informed of participant drug al- } \\
\text { location }\end{array}$ \\
\hline
\end{tabular}


CDP 1975 (Continued)

Blinding of outcome as-
sessment (detection bias) $\quad$ Unclear risk Not reported

All outcomes

\begin{tabular}{|c|c|c|}
\hline $\begin{array}{l}\text { Incomplete outcome data } \\
\text { (attrition bias) } \\
\text { All outcomes }\end{array}$ & Low risk & $\begin{array}{l}\text { "Only four dropout patients (three in niacin, and one in placebo) have been } \\
\text { lost to follow-up such that their vital status at the five year follow-up was not } \\
\text { known." Events/missing: } 237 / 3 \text { in intervention and 583/1 in control }\end{array}$ \\
\hline $\begin{array}{l}\text { Selective reporting (re- } \\
\text { porting bias) }\end{array}$ & Unclear risk & Protocol published after end of recruitment, registered retrospectively \\
\hline Other bias & Low risk & None \\
\hline
\end{tabular}

Goldberg 2000

Methods Design: parallel-group

Recruitment: 131 participants in 8 study centres in the USA (time period not reported)

Setting: not reported

Funding: this study was supported by Kos Pharmaceuticals, Inc., Miami, Florida

Participants Inclusion criteria: either average $L D L-C \geq 190 \mathrm{mg} / \mathrm{dL}$ and no $\mathrm{CHD}$ risk factors, or average $\mathrm{LDL}>160$ and $<190 \mathrm{mg} / \mathrm{dL}$ and a minimum of $2 \mathrm{CHD}$ risk factors

Exclusion criteria: secondary hyperlipoproteinaemia, type I or uncontrolled type II diabetes mellitus, baseline alanine aminotransferase levels $>1.3$ times the upper limit of normal, active peptic ulcer disease, gout, and hyperuricaemia.

Run-in/enrichment: 6-week, diet run-in followed by a 2-week phase to determine LDL-C stability

\section{Baseline characteristics:}

Age: mean 54 years, range $21-75$

Men: $59 \%$

Diabetes: not reported (but part of exclusion criteria)

Current smoker: not reported

Prior MI/established CHD: not reported

Hypertension: not reported

Statin therapy: not reported

Arm 1: niacin extended-release $3000 \mathrm{mg} /$ day

1 dose at bedtime. Initial dosing with extended-release placebo was $375 \mathrm{mg} /$ day, raised to $500 \mathrm{mg} / \mathrm{day}$, and further increased in 500-mg increments at 4-week intervals to a maximum of $3000 \mathrm{mg} / \mathrm{day}$ (randomised $=87$, complete cases $=46$ )

Arm 2: placebo (randomised $=44$, complete cases $=34$ )

Duration of treatment: 25 weeks maximum

Measure to prevent flushing/unblinding due to flushing: extended-release, medication at bedtime, $325 \mathrm{mg}$ aspirin $30 \mathrm{~min}$ before medication 
Goldberg 2000 (Continued)

Background therapy: not reported

\begin{tabular}{|c|c|c|}
\hline Outcomes & \multicolumn{2}{|c|}{$\begin{array}{l}\text { Primary outcome: LDL-C and apolipoprotein B levels } \\
\text { Secondary outcome: TC, HDL-C, VLDL, plasma TG, HDL subfractions, apolipoprotein A-1, and lipopro- } \\
\text { tein(a) }\end{array}$} \\
\hline Notes & \multicolumn{2}{|c|}{$\begin{array}{l}\text { Compliance: not reported } \\
\text { Registration: not reported }\end{array}$} \\
\hline \multicolumn{3}{|l|}{ Risk of bias } \\
\hline Bias & Authors' judgement & Support for judgement \\
\hline $\begin{array}{l}\text { Random sequence genera- } \\
\text { tion (selection bias) }\end{array}$ & Unclear risk & Not reported \\
\hline $\begin{array}{l}\text { Allocation concealment } \\
\text { (selection bias) }\end{array}$ & Unclear risk & Not reported \\
\hline $\begin{array}{l}\text { Blinding of participants } \\
\text { and personnel (perfor- } \\
\text { mance bias) } \\
\text { All outcomes }\end{array}$ & Low risk & "Double-blind" \\
\hline $\begin{array}{l}\text { Blinding of outcome as- } \\
\text { sessment (detection bias) } \\
\text { All outcomes }\end{array}$ & Unclear risk & Not reported, low for participant-reported outcomes \\
\hline $\begin{array}{l}\text { Incomplete outcome data } \\
\text { (attrition bias) } \\
\text { All outcomes }\end{array}$ & High risk & $\begin{array}{l}\text { Proportion of missing data: } 47 \% \text { in intervention and } 23 \% \text { in control; events/ } \\
\text { missing: } 0 / 41 \text { in intervention and } 1 / 10 \text { in control }\end{array}$ \\
\hline $\begin{array}{l}\text { Selective reporting (re- } \\
\text { porting bias) }\end{array}$ & Unclear risk & No protocol published, not registered \\
\hline Other bias & Low risk & None \\
\hline
\end{tabular}

\section{Guyton 2008}

Design: parallel-group
Recruitment: 1220 participants from 2005-2008 in 106 study centres in the USA
Setting: not reported
Funding: Merck/Schering-Plough Pharmaceuticals

Participants

Inclusion criteria: aged 18-79 years, LDL-C levels $(130 \mathrm{mg} / \mathrm{dL}-190 \mathrm{mg} / \mathrm{dL})$, triglyceride levels ( $\leq 500 \mathrm{mg} /$ $\mathrm{dL}$ ), and metabolic and clinical stability (e.g. euthyroid, creatinine $<2 \mathrm{mg} / \mathrm{dL}$, creatinine kinase $\leq 2 \mathrm{x}$ ULN, transaminases $\leq 1.5 \times$ ULN) were eligible for inclusion in the study

Exclusion criteria: not reported

Run-in/enrichment: 4-week washout period

\section{Baseline characteristics}


Guyton 2008 (Continued)

Age: mean 57 years, SD 10.5

Men: $50 \%$

Diabetes: $16 \%$

Current smoker: not reported

Prior MI/established CHD: 9\%

Hypertension: $65 \%$

Statin therapy: $100 \%$ (part of interventions)

Arm 1: ezetimibe/simvastatin (10/20 mg/day) + niacin (titrated to $2 \mathrm{~g} /$ day) (randomised = 676, complete cases $=391$ )

Arm 2: niacin (titrated to $2 \mathrm{~g} /$ day)

Arm 3: ezetimibe/simvastatin (10/20 mg/day) (randomised $=272$, complete cases $=213$ )

We included the comparison arm 1 vs arm 3

Duration of treatment: maximum 24 weeks (first part of a 64-week study)

Measure to prevent flushing/unblinding due to flushing: participants were consulted to take niacin at bedtime with a low-fat snack, aspirin ( $325 \mathrm{mg}$ ), or ibuprofen $(200 \mathrm{mg}) 30 \mathrm{~min}$ before taking niacin, and to avoid alcoholic and hot beverages near the time of taking niacin

Background therapy: not reported

\begin{tabular}{ll}
\hline Outcomes & Primary outcome: LDL-C \\
& Secondary outcomes: non-HDL-C, HDL-C, TG, LDL-C, non-HDL-C, TC, apolipoprotein B, ApoA-I, lipid/ \\
lipoprotein ratio, and high- sensitivity C-reactive protein
\end{tabular}

lipoprotein ratio, and high- sensitivity C-reactive protein

Notes Compliance: not reported

Registration: NCT00271817

\section{Risk of bias}

\begin{tabular}{lll}
\hline Bias & Authors' judgement & Support for judgement \\
\hline $\begin{array}{l}\text { Random sequence genera- } \\
\text { tion (selection bias) }\end{array}$ & Low risk & Not reported, probably low risk of bias \\
\hline $\begin{array}{l}\text { Allocation concealment } \\
\text { (selection bias) }\end{array}$ & Low risk & "Central allocation" \\
\hline $\begin{array}{l}\text { Blinding of participants } \\
\begin{array}{l}\text { and personnel (perfor- } \\
\text { mance bias) } \\
\text { All outcomes }\end{array}\end{array}$ & Low risk & "All study personnel remained blinded to treatment allocation" \\
\hline
\end{tabular}

Blinding of outcome as- Low risk $\quad$ "All study personnel remained blinded to treatment allocation"
sessment (detection bias)
All outcomes

Incomplete outcome data High risk (attrition bias)

Proportion of missing data: $42 \%$ in intervention and $22 \%$ in control; events/ missing: 0/285 in intervention and 0/59 in control

All outcomes 
Guyton 2008 (Continued)

Selective reporting (re- Unclear risk No protocol published, prospectively registered but clinical outcomes not preporting bias) specified

Other bias Low risk None

Harikrishnan 2008

$\begin{array}{ll}\text { Methods } & \text { Design: parallel-group } \\ \text { Recruitment: } 210 \text { from } 1 \text { centre in India } \\ \text { Setting: tertiary care } \\ \text { Funding: Reagent kits sponsored by Reddys laboratories, a Pharma company }\end{array}$

Participants

Inclusion criteria: aged 30-70 years, at least 6 months on statin therapy, at least 2 months on atorvastatin therapy, $\mathrm{HDL} \leq 35 \mathrm{mg} / \mathrm{dL}$, adhering to NYHA step II diet

Exclusion criteria: triglyceride $>300 \mathrm{mg} / \mathrm{dL}$, hepatobiliary and renal disease, type I diabetes or poorly-controlled diabetes, secondary forms of hyperlipidaemia, acute MI or unstable angina, hypothyroidism, gout and hyperuricaemia, left ventricular dysfunction

Run-in/enrichment: 8 weeks of atorvastatin if participants were taking an other statin

\section{Baseline characteristics (based on comparison of interest)}

Age: mean 52.5 years, range $22-70$

Men: $97 \%$

Diabetes: not reported

Current smoker: not reported

Prior MI/established CHD: 65\%

Hypertension: not reported

Statin therapy: $100 \%$ (part of intervention)

Arm 1: niacin $1.5 \mathrm{~g} /$ day + atorvastatin (randomised = 104, complete cases $=102$ )

Arm 2: atorvastatin (randomised $=106$, complete cases $=102$ )

Duration of treatment: 9 months, SD 1.8 months

Measure to prevent flushing/unblinding due to flushing: aspirin along with niaci (dose not reported)

Background therapy: for uniformity in interpreting data, only participants on atorvastatin were included. Those participants who were taking a statin other than atorvastatin entered the trial after a run-in period of 8 weeks of atorvastatin after stopping the other statin. Atorvastatin was used in conventional dosages as would be required for target LDL-C levels

Outcomes

Primary outcome: not defined

Outcomes: completion 8 months' follow-up, intolerance attributable to study drug which participant feels unable to continue, rise in liver enzymes, rise in creatin kinase asymptomatic, generalised muscle pain/tenderness, worsening glucose intolerance/diabetes 
Harikrishnan 2008 (Continued)

Registration: not reported

\section{Risk of bias}

\begin{tabular}{|c|c|c|}
\hline Bias & Authors' judgement & Support for judgement \\
\hline $\begin{array}{l}\text { Random sequence genera- } \\
\text { tion (selection bias) }\end{array}$ & High risk & Quasi randomised, alternating weekly according to authors \\
\hline $\begin{array}{l}\text { Allocation concealment } \\
\text { (selection bias) }\end{array}$ & High risk & Quasi randomised, alternating weekly according to authors \\
\hline $\begin{array}{l}\text { Blinding of participants } \\
\text { and personnel (perfor- } \\
\text { mance bias) } \\
\text { All outcomes }\end{array}$ & High risk & "Open label" \\
\hline $\begin{array}{l}\text { Blinding of outcome as- } \\
\text { sessment (detection bias) } \\
\text { All outcomes }\end{array}$ & High risk & "Open label" \\
\hline $\begin{array}{l}\text { Incomplete outcome data } \\
\text { (attrition bias) } \\
\text { All outcomes }\end{array}$ & Low risk & $\begin{array}{l}\text { Outcome mortality not reported. Outcome "discontinuation of treatment due } \\
\text { to side effects": proportion of missing data, } 2 \% \text { in intervention and } 4 \% \text { in con- } \\
\text { trol; events/missing: } 4 / 2 \text { in intervention, } 1 / 4 \text { in control }\end{array}$ \\
\hline $\begin{array}{l}\text { Selective reporting (re- } \\
\text { porting bias) }\end{array}$ & Unclear risk & No protocol published, not registered \\
\hline Other bias & Low risk & None \\
\hline
\end{tabular}

Heart positive 2011

Design: parallel-group
Recruitment: 221 from > 3 centres in the USA (time span and exact number of centres not reported)
Setting: primary and secondary care
Funding: National Institutes of Health, Baylor College of Medicine General Clinical Research Center.
Study drugs provided by Abbott Laboratories, Neither the NIH nor Abbott had any role in the design or
conduct of the study; collection, management, analysis, or interpretation of the data; or preparation,
review, or approval of the manuscript. Abbott asked to read a draft of the manuscript before its submis-
sion for publication

Participants

Inclusion criteria: HIV, 21-65 years, stable highly active antiretroviral therapy (HAART) regimen for a minimum of 6 months, fasting serum triglyceride level $1.7 \mathrm{mmol} / \mathrm{L}$, body mass index $\geq 18.5$ and $\leq 30$

Exclusion criteria: fasting serum triglyceride level $\geq 11.3 \mathrm{mmol} / \mathrm{L}$, diabetes, use of any medications known to affect lipid or lipoprotein metabolism including, nutritional supplements (including but not limited to fish oils, creatine), steroidal compounds or anabolic agents, inability to perform the prescribed graded exercise regimen, CD4 cell count less than $200 \times 106$ cells/L, or presence of an opportunistic infection or conditions likely to prevent the subject from completing the required exercise regimen through the course of the study, history of symptomatic coronary artery disease (MI, angina) or peripheral vascular disease (claudication). Conditions that could affect drug safety including known adverse reactions to niacin or fibrates, serum alanine or aspartate aminotransferase level greater than two-fold the ULN adult range, renal insufficiency, treatment with warfarin anticoagulants, pregnancy, history of myositis or rhabdomyolysis, past or present alcohol abuse, peptic ulcer disease, cholelithiasis, and gout or hyperuricaemia 
Heart positive 2011 (Continued)

Run-in/enrichment: not reported

Baseline characteristics (based on comparison of interest)

Age: mean 43 years, SD 1.4

Men: $88 \%$

Diabetes: $0 \%$

Current smoker: not reported (58\% had history of smoking)

Prior MI/established CHD: 0\% (exclusion criterion)

Hypertension: not reported

Statin therapy: $0 \%$ (exclusion criterion)

Arm 1: usual care + guideline for nutrition and health

Arm 2: low-saturated-fat diet and exercise

Arm 3: low-saturated-fat diet and exercise + fenofibrate 145

Arm 4: low-saturated-fat diet and exercise + niacin $2 \mathrm{~g} /$ day

Arm 5: low-saturated-fat diet and exercise + fenofibrate $145 \mathrm{mg}+$ niacin $2 \mathrm{~g} /$ day

We included the comparison pooled arms $4+5$ (randomised $=92$, complete cases $=49$ ) vs pooled arms $2+3$ (randomised $=88$, complete cases $=53$ )

Duration of treatment: 6 months maximum

Diet: education in weight-maintaining diet with $50 \%$ of calories from carbohydrates, $30 \%$ of calories from fat, cholesterol no greater than $200 \mathrm{mg} / \mathrm{d}$, and fibre $20-30 \mathrm{~g} / \mathrm{d}$

Exercise: exercise programme at a study gymnasium, following guidelines of the American College of Sports Medicine. The sessions were supervised by certified trainers 3/weekly for 75-90 min, with aerobic and resistance components

We compared pooled arms $4+5$ vs pooled arms $2+3$

Measure to prevent flushing/unblinding due to flushing: placebo contained $50 \mathrm{mg}$ niacin

Background therapy: not reported

Secondary outcomes: insulin sensitivity, glycaemia, adiponectin, C-reactive protein, energy expenditure, body composition

$\begin{array}{ll}\text { Notes } & \text { Compliance: } \text { not reported } \\ & \text { Registration: NCT00246376 }\end{array}$

\section{Risk of bias}

\begin{tabular}{lll}
\hline Bias & Authors' judgement & Support for judgement \\
\hline $\begin{array}{l}\text { Random sequence genera- } \\
\text { tion (selection bias) }\end{array}$ & Low risk & "Random number table" \\
\hline
\end{tabular}


Heart positive 2011 (Continued)

Allocation concealment High risk "Study personnel were blinded to group allocations except for the person who (selection bias) performed the randomisation and acted as liaison between the pharmacy and the clinical coordinator"
Blinding of participants Low risk "Double blind", "placebo-controlled" and personnel (perfor-

mance bias)

All outcomes

\begin{tabular}{lll}
\hline $\begin{array}{l}\text { Blinding of outcome as- } \\
\text { sessment (detection bias) } \\
\text { All outcomes }\end{array}$ & Unclear risk & Not reported, low risk of bias for participant-reported outcomes \\
\hline $\begin{array}{l}\text { Incomplete outcome data } \\
\text { (attrition bias) }\end{array}$ & High risk & $\begin{array}{l}\text { Outcome 'mortality' not reported. Outcome 'flushing': proportion of missing } \\
\text { data, } 47 \% \text { in intervention and } 40 \% \text { in control; events/missing: } 16 / 26 \text { in inter- } \\
\text { vention, } 2 / 19 \text { in control }\end{array}$ \\
\hline
\end{tabular}

\begin{tabular}{lll}
\hline $\begin{array}{l}\text { Selective reporting (re- } \\
\text { porting bias) }\end{array}$ & Unclear risk & Protocol published and registered, clinical outcomes not pre-specified \\
\hline Other bias & Low risk & None \\
\hline
\end{tabular}

$\begin{array}{ll}\text { Methods } & \text { Design: parallel-group } \\ & \text { Recruitment: } 25,673 \text { participants from 2007-2010 in } 245 \text { centres in China, UK, Denmark, Finland, Nor- } \\ & \text { way, and Sweden }\end{array}$

Setting: secondary and tertiary care

Funding: Merck

Participants

Inclusion criteria: history of $\mathrm{Ml}$, cerebrovascular atherosclerotic disease; or peripheral arterial disease, diabetes mellitus with any of the above or with other evidence of symptomatic CHD

Exclusion criteria: $<50$ or $>80$ years, acute MI, coronary syndrome or stroke within 3 months; planned revascularisation procedure, history of chronic liver disease, or abnormal liver function, breathlessness at rest for any reason, renal insufficiency, active inflammatory muscle disease, adverse reaction to a statin, ezetimibe, niacin or laropiprant, active peptic ulcer, concurrent treatment with fibrate, niacin, ezetimibe, statin, potent CYP3A4 inhibitor, ciclosporin, amiodarone, verapamil, danazol, known to be poorly compliant with clinic visits or prescribed medication; medical history that might limit the individual's ability to take trial treatments for the duration of the study

Run-in/enrichment: 4 weeks to standardised simvastatin $40 \mathrm{mg}$ daily or, if not sufficient to achieve a $\mathrm{TC}<3.5 \mathrm{mmol} / \mathrm{L}$ when measured after 4 weeks, simvastatin $40 \mathrm{mg}$ plus ezetimibe $10 \mathrm{mg}$ daily

\section{Baseline characteristics}

Age: mean 64.9 years, SD 7.5

Men: $83 \%$

Diabetes: $32 \%$

Current smoker: $18 \%$

Prior MI/established CHD: $78 \%$ 
HPS2-THRIVE 2014 (Continued)

Hypertension: 62\% (treated hypertension)

Statin therapy: 100\% (background therapy)

Interventions Arm 1: niacin extended-release $2 \mathrm{~g}$ plus laropiprant $40 \mathrm{mg}$ daily (randomised $=12,838$, complete cases

$=12,730$ )

Arm 2: matching placebo (randomised $=12,835$, complete cases $=12,745$ )

Duration of treatment: median of 3.9 years

Measure to prevent flushing/unblinding due to flushing: extended-release

Background therapy: statin-based LDL-C-lowering therapy

\begin{tabular}{|c|c|c|}
\hline Outcomes & \multicolumn{2}{|c|}{$\begin{array}{l}\text { Primary outcome: composite of first non-fatal MI, coronary death, stroke, or arterial revascularisation } \\
\text { Secondary outcome: major coronary events, non-fatal MI or coronary death }\end{array}$} \\
\hline Notes & \multicolumn{2}{|c|}{$\begin{array}{l}\text { Compliance: } 75 \% \text { in intervention, } 83 \% \text { in control } \\
\text { Registration: NCT00461630 and ISRCTN29503772 }\end{array}$} \\
\hline \multicolumn{3}{|l|}{ Risk of bias } \\
\hline Bias & Authors' judgement & Support for judgement \\
\hline $\begin{array}{l}\text { Random sequence genera- } \\
\text { tion (selection bias) }\end{array}$ & Low risk & $\begin{array}{l}\text { "Randomization... was provided by the study clinic computer which was syn- } \\
\text { chronized frequently with the study database at the coordinating centre in the } \\
\text { Clinical Trial Service Unit, Oxford via secure Internet connection." }\end{array}$ \\
\hline $\begin{array}{l}\text { Allocation concealment } \\
\text { (selection bias) }\end{array}$ & Low risk & Central randomisation \\
\hline $\begin{array}{l}\text { Blinding of participants } \\
\text { and personnel (perfor- } \\
\text { mance bias) } \\
\text { All outcomes }\end{array}$ & Low risk & "Double-blind" \\
\hline
\end{tabular}

Blinding of outcome as- Low risk "Blind to treatment allocation"

sessment (detection bias)

All outcomes

Incomplete outcome data Low risk

(attrition bias)

Proportion of missing data: $1 \%$ in both arms; events/missing: 798/108 in inter-

All outcomes vention and 732/90 in control

\begin{tabular}{lll}
\hline $\begin{array}{l}\text { Selective reporting (re- } \\
\text { porting bias) }\end{array}$ & Low risk & $\begin{array}{l}\text { All outcomes pre-specified in the prospectively published trial registry record } \\
\text { were subsequently reported }\end{array}$ \\
\hline Other bias & Low risk & None \\
\hline
\end{tabular}

Hunninghake 2003

$\begin{array}{ll}\text { Methods } & \text { Design: parallel-group } \\ \text { Recruitment: } 237 \text { in } 1999 \text { from } 23 \text { centres in the USA } \\ \text { Setting: not reported }\end{array}$


Funding: Kos Pharmaceuticals, Inc

Participants Inclusion criteria: $\geq 18$ years, elevated LDL-C levels or elevated LDL-C and TG levels.

Exclusion criteria: TG $>800 \mathrm{mg} / \mathrm{dL}$, hepatic dysfunction, renal disease, biliary disease, severe hypertension, recent major vascular event, peptic ulcer, gout, type 1 or uncontrolled type 2 diabetes mellitus, cancer, risk of pregnancy, statin within 4 weeks

Run-in/enrichment: 6 weeks' wash out and baseline evaluation

\section{Baseline characteristics (based on comparison of interest)}

Age: mean 59 years, SD 12

Men: $51 \%$

Diabetes: not reported

Current smoker: not reported

Prior MI/established CHD: not reported

Hypertension: not reported

Statin therapy: $100 \%$ (part of the intervention)

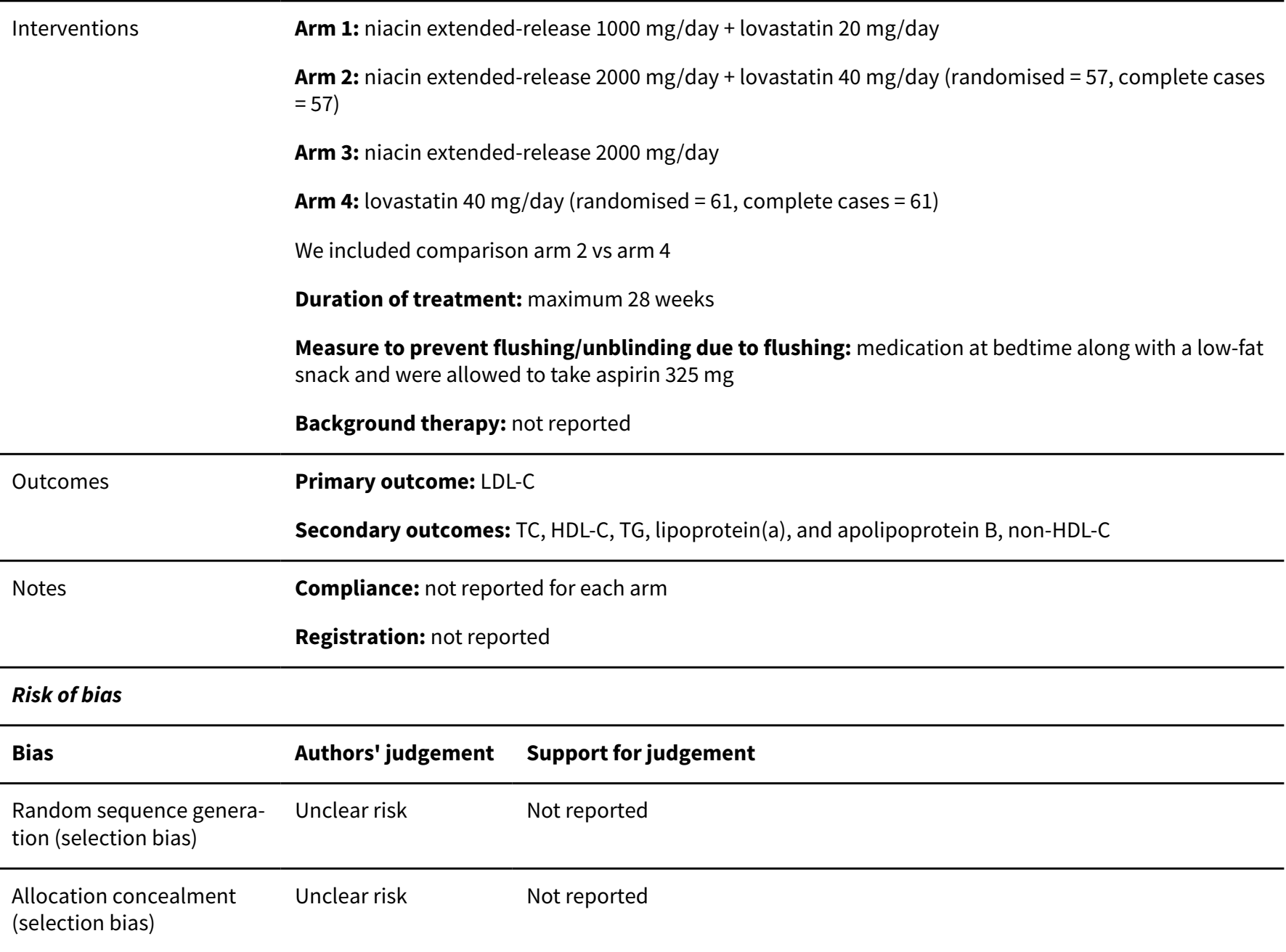


Hunninghake 2003 (Continued)

$\begin{array}{ll}\begin{array}{l}\text { Blinding of participants } \\ \text { and personnel (perfor- }\end{array} & \text { "Double-blind", "Several measures were undertaken to ensure blinding. First, } \\ \text { mance bias) } & \begin{array}{l}\text { all study medications were identical in shape, size, and colour. Second, equal } \\ \text { numbers of active treatment and matched placebo tablets were administered }\end{array} \\ \text { All outcomes } & \text { to all four treatment groups during each phase of the study" }\end{array}$

Not reported, low risk of bias for participant-reported outcomes

Blinding of outcome as-

Unclear risk

All outcomes

Incomplete outcome data Unclear risk Loss to follow-up per group not reported
(attrition bias)

All outcomes

\begin{tabular}{lll}
\hline $\begin{array}{l}\text { Selective reporting (re- } \\
\text { porting bias) }\end{array}$ & Unclear risk & Protocol published retrospectively, not registered \\
\hline Other bias & Low risk & None \\
\hline
\end{tabular}

Lee 2009

Design: parallel groups
Recruitment: 71 participants from a single centre in the UK (time period not reported)
Setting: not reported
Funding: investigator-initiated study funded by Merck KGaA

Participants

Inclusion criteria: $\mathrm{HDL}-\mathrm{C}<40 \mathrm{mg} / \mathrm{dL}$ in previous 12 months and carotid atherosclerosis or peripheral arterial disease

Exclusion criteria: contraindications to MRI or to niacin; severe carotid stenosis ( $>70 \%)$; treatment with fibrates, nicorandil, or oral nitrates, recent acute coronary syndrome; uncontrolled diabetes; fasting triglyceride level $>500 \mathrm{mg} / \mathrm{dL}$; peptic ulcer; cardiac failure requiring diuretic treatment

Run-in/enrichment: not reported

\section{Baseline characteristics}

Total randomised: 71

Age: mean 65, SD 9

Men: $94 \%$

Diabetes: 65\%

Current smoker: $83 \%$

Prior MI/established CHD: $48 \%$

Hypertension: $78 \%$

Statin therapy: $100 \%$

Interventions

Arm 1: nicotinic acid was increased on a weekly basis from $375 \mathrm{mg}$ to $500 \mathrm{mg}$, and then to $750 \mathrm{mg}$ daily. Participants subsequently received $1000 \mathrm{mg}$ for 4 weeks, $1500 \mathrm{mg}$ for a further 4 weeks, and then 2000 $\mathrm{mg}$ daily for the remainder of the study (randomised $=35$, complete cases $=25$ )

Arm 2: placebo (randomised $=36$, complete cases $=30$ ) 
Duration of treatment: maximum 12 months

Measure to prevent flushing/unblinding due to flushing: medication at night, together with aspirin

Background therapy: not reported

\begin{tabular}{|c|c|c|}
\hline Outcomes & \multicolumn{2}{|c|}{$\begin{array}{l}\text { Primary outcome: carotid artery wall area } \\
\text { Secondary outcomes: other MRI outcomes }\end{array}$} \\
\hline Notes & \multicolumn{2}{|c|}{$\begin{array}{l}\text { Compliance: niacin }(93 \%) \text { and placebo }(92 \%) \text { based on pill count } \\
\text { Registration: NCT00232531 }\end{array}$} \\
\hline \multicolumn{3}{|l|}{ Risk of bias } \\
\hline Bias & Authors' judgement & Support for judgement \\
\hline $\begin{array}{l}\text { Random sequence genera- } \\
\text { tion (selection bias) }\end{array}$ & Low risk & "Computer generated" \\
\hline $\begin{array}{l}\text { Allocation concealment } \\
\text { (selection bias) }\end{array}$ & Unclear risk & Not reported \\
\hline $\begin{array}{l}\text { Blinding of participants } \\
\text { and personnel (perfor- } \\
\text { mance bias) } \\
\text { All outcomes }\end{array}$ & Low risk & "Double-blind" \\
\hline $\begin{array}{l}\text { Blinding of outcome as- } \\
\text { sessment (detection bias) } \\
\text { All outcomes }\end{array}$ & Unclear risk & Not reported, low risk of bias for participant-reported outcomes \\
\hline $\begin{array}{l}\text { Incomplete outcome data } \\
\text { (attrition bias) } \\
\text { All outcomes }\end{array}$ & High risk & $\begin{array}{l}\text { Outcome "mortality" not reported. Outcome "discontinuation of treatment } \\
\text { due to side effects": proportion of missing data, } 17 \% \text { in intervention and } 14 \% \\
\text { in control; events/missing: } 7 / 6 \text { in intervention, } 2 / 5 \text { in control }\end{array}$ \\
\hline $\begin{array}{l}\text { Selective reporting (re- } \\
\text { porting bias) }\end{array}$ & Unclear risk & No protocol published, clinical outcomes not specified in registry \\
\hline Other bias & Low risk & None \\
\hline
\end{tabular}

Lee 2011

Methods

Design: pilot, parallel

Recruitment: 28 participants from 1987-1989 in 6 centres in Korea

Setting: not reported

Funding: Korean Society of Circulation (Industrial-Educational Cooperation 2006)

Participants

Inclusion criteria: $20-70$ years, coronary stenosis in angiogram, and who had not been taking, hormone therapy or anti-oxidant vitamins within the previous 2 months.

Exclusion criteria: cholesterol lowering, anti-oxidants, or hormones within 2 months, premenopausal women, hypercholesterolaemia, cyclosporine or antifungal agents (azole), severe left ventricular dysfunction, liver disease, renal dysfunction, hypothyroidism, ileal bypass. 
Lee 2011 (Continued)

Run-in/enrichment: not reported

\section{Baseline characteristics}

Age: mean 60, SD 7

Men: $50 \%$

Diabetes: $46 \%$

Current smoker: $29 \%$

Prior MI/established CHD: $57 \%$

Hypertension: $32 \%$

Statin therapy: 100\% (part of intervention)

Arm 2: simvastatin $40 \mathrm{mg}$ (randomised $=14$, complete cases $=14$ )

Duration of treatment: maximum 9 months

Measure to prevent flushing/unblinding due to flushing: medication at night

Background therapy: not reported

\section{Outcomes}

Primary outcomes: normalised total atheroma volume, percent atheroma volume, C-reactive protein, matrix metalloproteinase-9, soluble CD40 ligand

Secondary outcome: secondary end points were changes in high sensitivity C-reactive protein, matrix metalloproteinase- 9 and soluble CD40 ligand

\begin{tabular}{ll}
\hline Notes & Compliance: not reported \\
Registration: not reported
\end{tabular}

\section{Risk of bias}

\begin{tabular}{lll}
\hline Bias & Authors' judgement & Support for judgement \\
\hline $\begin{array}{l}\text { Random sequence genera- } \\
\text { tion (selection bias) }\end{array}$ & Low risk & "Computer-generated" \\
\hline $\begin{array}{l}\text { Allocation concealment } \\
\text { (selection bias) }\end{array}$ & Unclear risk & Not reported \\
\hline
\end{tabular}

Blinding of participants $\quad$ High risk
and personnel (perfor-
mance bias)

Blinding of outcome as- High risk "Open-label"

Incomplete outcome data Low risk No missing data reported
(attrition bias)
All outcomes


Lee 2011 (Continued)
Selective reporting (re-
Unclear risk
No protocol published, not registered porting bias)

Other bias Low risk None

Linke 2009

Design: parallel-group
Recruitment: 60 participants in 6 centres in Germany (timeframe not reported)
Setting: not reported
Funding: Merck (not involved in either the study design or the data analysis) and Leipzig University,
Germany

Participants Inclusion criteria: between 35 and 65 years $\mathrm{HDL}-\mathrm{C}<1.0 \mathrm{mmol} / \mathrm{L}$. Impaired glucose tolerance, absence inflammatory disease, undetectable antiGAD antibodies, (3) systolic BP $<140 \mathrm{mmHg}$, diastolic BP $<90$ $\mathrm{mmHg}$

Exclusion: cardiovascular or peripheral artery disease, thyroid dysfunction, concomitant medication intake, alcohol or drug abuse, pregnancy, impaired liver function, impaired renal function

Run-in/enrichment: not reported

\section{Baseline characteristics}

Age: mean 45 years, SD 4

Men: $70 \%$

Diabetes: $0 \%$ (exclusion criterion)

Current smoker: not reported

Prior MI/established CHD: 0\% (exclusion criterion)

Hypertension: $0 \%$ (exclusion criterion)

Statin therapy: $0 \%$ (exclusion criterion)

Arm 2: Usual care, any medication or lifestyle intervention (randomised $=30$, complete cases $=30$ )

Duration of treatment: maximum 6 months

Measure to prevent flushing/unblinding due to flushing: extended-release, aspirin $300 \mathrm{mg}$

Background therapy: not reported

\begin{tabular}{ll}
\hline Outcomes & Primary outcome: not reported \\
& Secondary outcome: not reported
\end{tabular}

Notes

Compliance: $100 \%$

Registration: not reported

\section{Risk of bias}


Linke 2009 (Continued)

\begin{tabular}{lll} 
Bias & Authors' judgement & Support for judgement \\
\hline $\begin{array}{l}\text { Random sequence genera- } \\
\text { tion (selection bias) }\end{array}$ & Unclear risk & Not reported \\
\hline $\begin{array}{l}\text { Allocation concealment } \\
\text { (selection bias) }\end{array}$ & Unclear risk & Not reported \\
\hline $\begin{array}{l}\text { Blinding of participants } \\
\text { and personnel (perfor- } \\
\text { mance bias) } \\
\text { All outcomes }\end{array}$ & High risk & "Open-label" \\
\hline $\begin{array}{l}\text { Blinding of outcome as- } \\
\text { sessment (detection bias) } \\
\text { All outcomes }\end{array}$ & High risk & "Open-label" \\
\hline $\begin{array}{l}\text { Incomplete outcome data } \\
\text { (attrition bias) } \\
\text { All outcomes }\end{array}$ & Low risk & No missing data reported \\
\hline $\begin{array}{l}\text { Selective reporting (re- } \\
\text { porting bias) }\end{array}$ & Unclear risk & No protocol published, not registered \\
\hline \begin{tabular}{l} 
Other bias \\
\hline
\end{tabular} & Low risk & None \\
\hline
\end{tabular}

Maccubbin 2008

Methods Design: parallel

Recruitment: 1613 participants multiple centres worldwide (countries and timeframe not reported)

Setting: not reported

Funding: Merck

Participants

Inclusion criteria: age 18-85, primary hypercholesterolaemia or mixed dyslipidaemia, ongoing statin, be at or below their National Cholesterol Education Program, LDL-C $<100 \mathrm{mg} / \mathrm{dL}$ for high-risk participants, $<130 \mathrm{mg} / \mathrm{dL}$ (3.37 mmoVL) for participants with multiple risk factors. 130-190 mg/dL for low-risk participants, $\mathrm{TG}<350 \mathrm{mg} / \mathrm{dL}$

Exclusion criteria: impaired renal function, impaired liver function, creatine kinase $>2 \times$ ULN or thyroid stimulating hormone outside the central laboratory's normal reference range. Experiencing menopausal flashes, poorly controlled, unstable, or new onset diabetes, various concomitant drugs

Run-in/enrichment: 4 weeks' placebo

\section{Baseline characteristics (based on all randomised participants)}

Total randomised: 1613 (813 in comparison of interest. Other arms: 800 in arm 1)

Age: mean 58, SD 11

Men: $61 \%$

Diabetes: $16 \%$

Current smoker: not reported 
Maccubbin 2008 (Continued)

Prior MI/established CHD: not reported

Hypertension: not reported

Statin therapy: $67 \%$

Arm 1: niacin extended-release $2000 \mathrm{mg} /$ day + laropiprant $40 \mathrm{mg} /$ day
Arm 2: niacin extended-release $2000 \mathrm{mg} / \mathrm{day}$
Arm 3: placebo
We included the comparison combined arms 1 and 2 (randomised = 1343, complete cases $=917)$ vs arm
$3($ randomised $=270$, complete cases $=239)$

$3($ randomised $=270$, complete cases $=239)$

Duration of treatment: Max 26 weeks

Measure to prevent flushing/unblinding due to flushing: extended-release, laropiprant, medication at bedtime after snack, aspirin $100 \mathrm{mg}$ permitted

Background therapy: Not reported

\begin{tabular}{|c|c|c|}
\hline Outcomes & \multicolumn{2}{|c|}{$\begin{array}{l}\text { Primary outcome: LDL-C levels, flushing } \\
\text { Secondary outcomes: additional lipid end-points, additional flushing end-points including discontinu- } \\
\text { ation of treatment due to flushing }\end{array}$} \\
\hline Notes & \multicolumn{2}{|c|}{$\begin{array}{l}\text { Compliance: not reported } \\
\text { Registration: NCT00269204 }\end{array}$} \\
\hline \multicolumn{3}{|l|}{ Risk of bias } \\
\hline Bias & Authors' judgement & Support for judgement \\
\hline $\begin{array}{l}\text { Random sequence genera- } \\
\text { tion (selection bias) }\end{array}$ & Low risk & Not reported, but probably low \\
\hline $\begin{array}{l}\text { Allocation concealment } \\
\text { (selection bias) }\end{array}$ & Low risk & $\begin{array}{l}\text { "Randomisation of study drug was achieved via an Interactive Voice Response } \\
\text { System" }\end{array}$ \\
\hline $\begin{array}{l}\text { Blinding of participants } \\
\text { and personnel (perfor- } \\
\text { mance bias) } \\
\text { All outcomes }\end{array}$ & Low risk & "Double-blind" \\
\hline
\end{tabular}

Blinding of outcome as- Unclear risk Not reported, low risk of bias for participant-reported outcomes sessment (detection bias)

All outcomes

\begin{tabular}{lll}
\hline $\begin{array}{l}\text { Incomplete outcome data } \\
\text { (attrition bias) } \\
\text { All outcomes }\end{array}$ & High risk & $\begin{array}{l}\text { Proportion of missing data: 32\% in intervention group, 12\% in control group; } \\
\text { event/missing: } 2 / 230 \text { in intervention and 0/31 in control }\end{array}$ \\
\hline $\begin{array}{l}\text { Selective reporting (re- } \\
\text { porting bias) }\end{array}$ & Unclear risk & No protocol published, clinical outcomes not specified in registry \\
\hline Other bias & Low risk & None \\
\hline
\end{tabular}


MacLean 2011

Design: parallel
Recruitment: 796 from $2007-2008$ in 32 centres in the USA and 62 international centres
Setting: not reported
Funding: Merck

Participants

Inclusion criteria: $18-80$ years, type 2 diabetes mellitus, stable dose of anti-diabetes mellitus medication, LDL-C between 1.55 and $2.97 \mathrm{mmol} / \mathrm{L}, \mathrm{TG} \leq 5.65 \mathrm{mmol} / \mathrm{L}$

Exclusion criteria: type 1 diabetes mellitus, renal dysfunction, liver dysfunction, elevated thyroid-stimulating hormones, poorly-controlled type 2 diabetes mellitus (within 3 months of randomisation), various concomitant drugs

Run-in/enrichment: 4 weeks lipid-modifying run-in period to attain LDL-C $<2.97 \mathrm{mmol} / \mathrm{L}$ if necessary

Baseline characteristics (based on all randomised participants)

Age: 62 years, SD 9.4

Men: $314 / 796,39 \%$

Diabetes: 796/796, 100\%

Current smoker: not reported

Prior MI/established CHD: not reported

Hypertension: not reported

Statin therapy: $78 \%$

Interventions Arm 1: extended-release niacin + laropiprant. Starting dose $1 \mathrm{~g} / 20 \mathrm{mg}$, doubled after 4 weeks of double-blind treatment to $2 \mathrm{~g} / 40 \mathrm{mg}$ (randomised $=454$, complete cases $=298$ )

Arm 2: placebo (randomised $=342$, complete cases $=277$ )

Duration of treatment: maximum 36 weeks

Measure to prevent flushing/unblinding due to flushing: extended-release, laropiprant

Background therapy: permitted lipid-altering therapies included fish oils, statins, fibrates, ezetimibe, ezetimibe/simvastatin combination tablet, and bile acid sequestrants

Outcomes Primary outcome: LDL-C levels

Secondary outcomes: other lipid endpoints and C-reactive protein

\begin{tabular}{ll}
\hline Notes & Compliance: not reported \\
& Registration: NCT00485758 \\
\hline
\end{tabular}

\section{Risk of bias}

\begin{tabular}{lll}
\hline Bias & Authors' judgement & Support for judgement \\
\hline $\begin{array}{l}\text { Random sequence genera- } \\
\text { tion (selection bias) }\end{array}$ & Unclear risk & Not reported \\
\hline $\begin{array}{l}\text { Allocation concealment } \\
\text { (selection bias) }\end{array}$ & Low risk & Interactive voice-response system \\
\hline
\end{tabular}


MacLean 2011 (Continued)

Blinding of participants Low risk "Double-blind"
and personnel (perfor-
mance bias)
All outcomes

\begin{tabular}{lll}
\hline $\begin{array}{l}\text { Blinding of outcome as- } \\
\text { sessment (detection bias) } \\
\text { All outcomes }\end{array}$ & Unclear risk & Not reported, low risk of bias for participant-reported outcomes \\
\hline $\begin{array}{l}\text { Incomplete outcome data } \\
\begin{array}{l}\text { (attrition bias) } \\
\text { All outcomes }\end{array}\end{array}$ & High risk & $\begin{array}{l}\text { Proportion of missing data: } 34 \% \text { in intervention and } 19 \% \text { in control; events/ } \\
\text { missing ratio: } 0 / 156 \text { for intervention and } 1 / 65 \text { for control }\end{array}$ \\
\hline $\begin{array}{l}\text { Selective reporting (re- } \\
\text { porting bias) }\end{array}$ & Unclear risk & No protocol published, clinical outcomes not specified in registry \\
\hline Other bias & Low risk & None \\
\hline
\end{tabular}

Nash 2011

Design: parallel
Recruitment: 97 participants in 3 centres in the USA
Setting: not reported
Funding: National Institute on Disability and Rehabilitation Research, US Department of Education;
and Kos Pharmaceuticals, Inc

Participants Inclusion criteria: 18-65 years, chronic tetraplegia for longer than 1 year, in good health and without evidence of acute illness

Exclusion criteria: recurrent acute infection or illness, trauma, or surgery within 6 months; pregnancy; previous MI or cardiac surgery; lipid-lowering therapy within 6 months; daily alcohol consumption; abnormal menstruation; lifestyle modifications within 6 months of study enrolment; various concomitant medication

\section{Run-in/enrichment: none}

\section{Baseline characteristics (based on all randomised participants)}

Age: Mean 33.0, SD 8.7

Men: not reported

Diabetes: mot reported

Current smoker: $0 \%$

Prior MI/established CHD: 0\% (exclusion criterion)

Hypertension: not reported

Statin therapy: not reported

Arm 2: extended-release niacin $2000 \mathrm{mg} /$ day (randomised $=31$, complete cases $=31$ )

Duration of treatment: maximum 48 weeks 
Nash 2011 (Continued)

Measure to prevent flushing/unblinding due to flushing: extended-release, 325-mg aspirin, niacin before bedtime after snack, avoidance of alcohol and hot drinks

Background therapy: not reported

\begin{tabular}{ll}
\hline Outcomes & Primary outcome: fasting HDL-C level and plasma TC/HDL-C ratio \\
& Secondary outcomes: other lipid outcomes \\
\hline Notes & Compliance: not reported \\
& Registration: not reported
\end{tabular}

Risk of bias

\begin{tabular}{|c|c|c|}
\hline Bias & Authors' judgement & Support for judgement \\
\hline $\begin{array}{l}\text { Random sequence genera- } \\
\text { tion (selection bias) }\end{array}$ & Low risk & Not reported but likely computer-generated, "permuted block design" \\
\hline $\begin{array}{l}\text { Allocation concealment } \\
\text { (selection bias) }\end{array}$ & Low risk & $\begin{array}{l}\text { Central allocation, "Study drug and placebo were dispensed, at the beginning } \\
\text { of each study month, by the research pharmacies located at each study site." }\end{array}$ \\
\hline $\begin{array}{l}\text { Blinding of participants } \\
\text { and personnel (perfor- } \\
\text { mance bias) } \\
\text { All outcomes }\end{array}$ & High risk & $\begin{array}{l}\text { "Single-blind design", "Subjects were masked from their group assignment } \\
\text { until after the study was completed or they withdrew from the trial" }\end{array}$ \\
\hline $\begin{array}{l}\text { Blinding of outcome as- } \\
\text { sessment (detection bias) } \\
\text { All outcomes }\end{array}$ & High risk & $\begin{array}{l}\text { "Single-blind design", "Subjects were masked from their group assignment } \\
\text { until after the study was completed or they withdrew from the trial" }\end{array}$ \\
\hline $\begin{array}{l}\text { Incomplete outcome data } \\
\text { (attrition bias) } \\
\text { All outcomes }\end{array}$ & Low risk & No missing data reported \\
\hline $\begin{array}{l}\text { Selective reporting (re- } \\
\text { porting bias) }\end{array}$ & Unclear risk & No protocol published, not registered \\
\hline Other bias & Low risk & None \\
\hline
\end{tabular}

NIA Plaque 2013

Design: parallel
Recruitment: 145 participants in a single centre in the USA (timeframe not reported)
Setting: secondary care
Funding: National Institute on Aging. Kos Pharmaceuticals, later acquired by Abbott Pharmaceuticals,
provided study drug at no cost and funding to complete data analysis

Participants

Inclusion criteria: $\geq 65$ years, history of cardio- vascular events or evidence of atherosclerosis, with baseline $\mathrm{LDL}<3.24 \mathrm{mmol} / \mathrm{L}$ if already on statin therapy and $<3.89 \mathrm{mmol} / \mathrm{L}$ if untreated.

Exclusion criteria: current use or intolerance of niacin, contraindication to MRI or gadolinium contrast, liver dysfunction, renal failure 
NIA Plaque 2013 (Continued)

\section{Run-in/enrichment: none}

\section{Baseline characteristics (based on all randomised participants)}

Age: 73 , interquartile range $69-77$

Men: $81 \%$

Diabetes: $26 \%$

Current smoker: $39 \%$

Prior MI/established CHD: $31 \%$

Hypertension: $78 \%$

Statin therapy: $100 \%$

Arm 1: placebo (randomised $=73$, complete cases $=58$ )

Arm 2: extended-release niacin $1500 \mathrm{mg} /$ day (randomised $=72$, complete cases $=59$ )

Duration of treatment: maximum 18 months

Measure to prevent flushing/unblinding due to flushing: extended-release

Background therapy: not reported

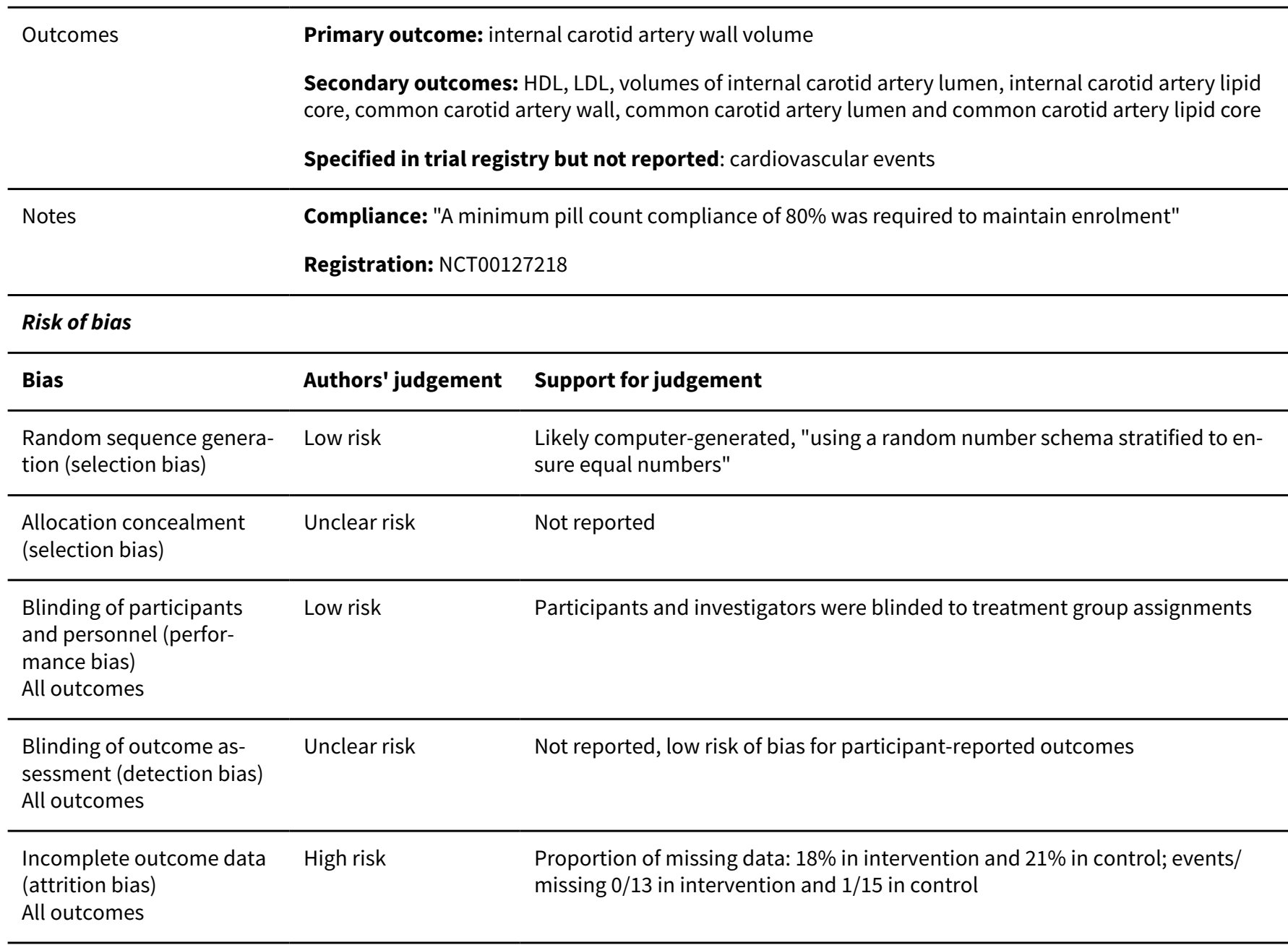


NIA Plaque 2013 (Continued)

$\begin{array}{lll}\begin{array}{l}\text { Selective reporting (re- } \\ \text { porting bias) }\end{array} & \text { High risk } & \begin{array}{l}\text { Cardiovascular events specified in registry record but subsequently not report- } \\ \text { ed }\end{array}\end{array}$
porting bias) ed

Other bias Low risk None

\section{PAST 1995}

\begin{tabular}{ll}
\hline Methods & Design: parallel \\
& Recruitment: 85 participants from 1986-1987 in Italy (number of centres not reported) \\
Setting: not reported \\
Funding: not reported
\end{tabular}

\section{Participants}

Inclusion criteria: 45-55 years, ischaemic heart disease

Exclusion criteria: presence of symptoms of carotid and/or femoral artery disease

Run-in / enrichment: not reported

\section{Baseline characteristics}

Age: 51 years, SD 3

Men: $95 \%$

Diabetes: $24 \%$

Current smoker: $31 \%$

Prior MI/established CHD: $89 \%$

Hypertension: $62 \%$

Statin therapy: not reported

Arm 1: hypolipidaemic diet (randomised $=45$, complete cases $=34$ )

Arm 2: hypolipidaemic diet + acipimox $500 \mathrm{mg} /$ day- $750 \mathrm{mg} /$ day (nicotinic compound) (randomised = 40 , complete cases $=30$ )

Duration of treatment: maximum 3 years

Measure to prevent flushing/unblinding due to flushing: not reported

Background therapy: not reported

\begin{tabular}{ll}
\hline Outcomes & Primary outcome: stenosis level of carotid and femoral artery \\
& Secondary outcome: not reported \\
\hline Notes & Compliance: "The compliance with drug treatment was good" \\
& Registration: not reported
\end{tabular}

\section{Risk of bias}

\section{Bias}

Authors' judgement Support for judgement 


\section{PAST 1995 (Continued)}

Random sequence genera- Unclear risk "Randomization was performed by utilizing a table of casual numbers; its setion (selection bias) quence was applied to the patients' list."

\begin{tabular}{|c|c|c|}
\hline $\begin{array}{l}\text { Allocation concealment } \\
\text { (selection bias) }\end{array}$ & Unclear risk & $\begin{array}{l}\text { "Randomization was performed by utilizing a table of casual numbers; its se- } \\
\text { quence was applied to the patients' list." }\end{array}$ \\
\hline
\end{tabular}

Blinding of participants High risk "Cardiologists and patients were aware of the distribution into groups"
and personnel (perfor-
mance bias)
All outcomes

\begin{tabular}{lll}
\hline $\begin{array}{l}\text { Blinding of outcome as- } \\
\text { sessment (detection bias) } \\
\text { All outcomes }\end{array}$ & High risk & "Cardiologists and patients were aware of the distribution into groups" \\
\hline $\begin{array}{l}\text { Incomplete outcome data } \\
\begin{array}{l}\text { (attrition bias) } \\
\text { All outcomes }\end{array}\end{array}$ & High risk & $\begin{array}{l}\text { Proportion of missing data: } 25 \% \text { in intervention and 24\% in control; events/ } \\
\text { missing ratio: } 3 / 10 \text { in intervention, } 4 / 11 \text { in control }\end{array}$ \\
\hline $\begin{array}{l}\text { Selective reporting (re- } \\
\text { porting bias) }\end{array}$ & Unclear risk & No protocol published, not registered \\
\hline Other bias & Low risk & None \\
\hline
\end{tabular}

\section{Sang 2009}

$\begin{array}{ll}\text { Methods } & \text { Design: parallel } \\ \text { Recruitment: } 108 \text { participants from 2006-2007 in a single centre in China } \\ \text { Setting: not reported } \\ \text { Funding: not reported }\end{array}$

Participants

Inclusion criteria: at least $50 \%$ stenosis of one coronary artery

Exclusion criteria: serious hepatic or kidney diseases; haemodynamic instability; cancer with expected survival < 1 year; administration of lipid-lowering drugs within the month before inclusion

Run-in/enrichment: not reported

Baseline characteristics:

Age: 71 years, SD 9

Men: $61 \%$

Diabetes: $65 \%$

Current smoker: not reported

Prior MI/established CHD: imbalance between groups: $36 \%$ control, $10 \%$ intervention

Hypertension: $67 \%$

Statin therapy: $100 \%$ (part of intervention) 
Arm 2: atorvastatin $10 \mathrm{mg} /$ day + extended-release niacin $1 \mathrm{~g} /$ day (randomised $=52$, complete cases $=$ 52)

Duration of treatment: maximum 12 months

Measure to prevent flushing/unblinding due to flushing: extended-release

Background therapy: all participants were given advice on lifestyle modification and smoking cessation as well as professional training in moderate exercise. They were permitted no lipid-modifying therapy other than the study drug

Outcomes Primary outcome: not defined

Outcomes: LDL-C, HDL-C, TC, TG, apolipoprotein A, apolipoprotein B, lipoprotein a, and fasting glucose, haemoglobin A1c, creatine kinase, creatine kinase MB isoenzyme, aspartate aminotransferase, alanine aminotransferase, adverse events, death from any cause, MI, rehospitalisation, revascularisation

Notes Compliance: not reported

Registration: not reported

\section{Risk of bias}

\begin{tabular}{|c|c|c|}
\hline Bias & Authors' judgement & Support for judgement \\
\hline $\begin{array}{l}\text { Random sequence genera- } \\
\text { tion (selection bias) }\end{array}$ & Unclear risk & Not reported \\
\hline $\begin{array}{l}\text { Allocation concealment } \\
\text { (selection bias) }\end{array}$ & Unclear risk & Not reported \\
\hline $\begin{array}{l}\text { Blinding of participants } \\
\text { and personnel (perfor- } \\
\text { mance bias) } \\
\text { All outcomes }\end{array}$ & Unclear risk & Not reported \\
\hline $\begin{array}{l}\text { Blinding of outcome as- } \\
\text { sessment (detection bias) } \\
\text { All outcomes }\end{array}$ & Unclear risk & Not reported \\
\hline $\begin{array}{l}\text { Incomplete outcome data } \\
\text { (attrition bias) } \\
\text { All outcomes }\end{array}$ & Unclear risk & Not reported \\
\hline $\begin{array}{l}\text { Selective reporting (re- } \\
\text { porting bias) }\end{array}$ & Unclear risk & No protocol published, not registered \\
\hline Other bias & High risk & $\begin{array}{l}\text { High risk of bias due to insufficient reporting of methods and substantial im- } \\
\text { balance of prognostic factors between groups }\end{array}$ \\
\hline
\end{tabular}

\section{Schoch 1968}

Design: parallel-groups; modified factorial (niacin x estrogen x thyroxin)
Recruitment: 570 US veterans between February 1963 and August 1966, number of centres not report-
ed
Setting: not reported


Funding: drugs supplied by the Ayerst Laboratories, the National Drug Company and Travenol Laboratories, Inc

\section{Participants} Inclusion criteria: only men; documented evidence of a transmural MI within 12 months prior to randomisation

Exclusion criteria: major medical diseases (other than atherosclerosis) which might lead to death in $<5$ years; presence of any medical condition in which the use of 1 of the 3 active therapeutic agents might be contraindicated

Run-in/enrichment: 1 month prior to randomisation; all participants received placebo.

\section{Baseline characteristics (based on all randomised participants)}

Age: $\leq 45$ years: $35 \%$; $46-65$ years: $47 \%$; $\geq 66$ years: $18 \%$

Men: $100 \%(570 / 570)$

Diabetes: 9\% (54/570)

Current smoker: not reported

Prior MI/established CHD: $100 \%$ (inclusion criterion)

Hypertension: 19\% (106/570)

Statin therapy: $0 \%$ (not available at the time) $\mathrm{mg}$ to $4.0 \mathrm{mg}$ daily over 4 months), and nicotinic acid (increasing from 1.0 to $4.0 \mathrm{mg}$ daily over $1 \mathrm{month}$ ) - or identical placebo:

Arm 1: placebo/placebo/placebo, $n=143$

Arm 2: estrogen/placebo/placebo, $n=141$

Arm 3: placebo/niacin/placebo, $n=77$

Arm 4: estrogen/niacin/placebo, $n=68$

Arm 5: placebo/placebo/thyroxin, $n=74$

Arm 6: estrogen/placebo/thyroxin, $n=67$

Duration of treatment: median 36 months

We compared pooled arms $3+4$ (niacin, randomised $=141$, complete cases $=140)$ to pooled arms $1+2$ (control, randomised $=284$, complete cases $=283$ )

\section{Measure to prevent flushing/unblinding due to flushing: none}

Background therapy: $50 \%$ received estrogen (due to factorial design)

Outcomes Primary outcome: serum cholesterol

Outcomes 'flushing' and 'diarrhoea' were only reported for all groups receiving niacin vs. and groups without niacin. Therefore, 33\% (141/425) of participants in the placebo group received thyroxin but no participants in the niacin group

\section{Secondary outcome: not reported}

Notes

Compliance: "Nicotinic acid caused the most troublesome side-effects, leading to frequent reduction in dosage. Some $28 \%$ of participants were maintained at full dose, another $32 \%$ had the drug discontinued altogether and the remaining $40 \%$ were at intermediate doses." 
Schoch 1968 (Continued)

Registration: not available at the time

Conflicting information about number of participants lost to follow-up proportions; proportions range between $8 \%$ and $50 \%$ for outcome 'overall mortality'

\section{Risk of bias}

\begin{tabular}{|c|c|c|}
\hline Bias & Authors' judgement & Support for judgement \\
\hline $\begin{array}{l}\text { Random sequence genera- } \\
\text { tion (selection bias) }\end{array}$ & Unclear risk & Not reported \\
\hline $\begin{array}{l}\text { Allocation concealment } \\
\text { (selection bias) }\end{array}$ & Low risk & $\begin{array}{l}\text { Medications were dispensed in the hospital pharmacy from bottles bearing } \\
\text { coded numbers }\end{array}$ \\
\hline $\begin{array}{l}\text { Blinding of participants } \\
\text { and personnel (perfor- } \\
\text { mance bias) } \\
\text { All outcomes }\end{array}$ & Low risk & "Double-blind" \\
\hline $\begin{array}{l}\text { Blinding of outcome as- } \\
\text { sessment (detection bias) } \\
\text { All outcomes }\end{array}$ & Unclear risk & Not reported, low risk of bias for participant-reported outcomes \\
\hline $\begin{array}{l}\text { Incomplete outcome data } \\
\text { (attrition bias) } \\
\text { All outcomes }\end{array}$ & Low risk & $\begin{array}{l}\text { Proportion of missing data: } 0.5 \% \text { in both groups; events/missing for overall } \\
\text { mortality: } 31 / 1 \text { in intervention, } 54 / 1 \text { in control }\end{array}$ \\
\hline $\begin{array}{l}\text { Selective reporting (re- } \\
\text { porting bias) }\end{array}$ & Unclear risk & No protocol published, not registered \\
\hline Other bias & Low risk & None \\
\hline
\end{tabular}

BP: blood pressure

CHD: coronary heart disease

HDL-C: high-density lipoprotein cholesterol

LDL-C: low-density lipoprotein cholesterol

MI: myocardial infarction

MRI: magnetic resonance imaging

NYHA: New York Heart Association

TC: total cholesterol

TG: triglycerides

ULN: upper limit of normal

VLDL: very low-density lipoprotein

Characteristics of excluded studies [ordered by study ID]

\begin{tabular}{ll}
\hline Study & Reason for exclusion \\
\hline AFREGS 2005 & No comparison of interest \\
\hline Airan-Javia 2009 & No outcome of interest \\
\hline ARBITER-6 2009 & No comparison of interest \\
\hline Arntz 2000 & No comparison of interest \\
\hline
\end{tabular}




\begin{tabular}{|c|c|}
\hline Study & Reason for exclusion \\
\hline Aronov 2001 & No outcome of interest \\
\hline Bays 2003 & Follow-up shorter than 6 months \\
\hline Blankenhorn 1987 & No comparison of interest \\
\hline Brown 1990a & No comparison of interest \\
\hline Cefali 2006 & Follow-up shorter than 6 months \\
\hline Cheung 2001a & No comparison of interest \\
\hline Cheung 2001b & No comparison of interest \\
\hline Dishy 2009 & Follow-up shorter than 6 months \\
\hline Dunbar 2009 & No comparison of interest \\
\hline FATS 2001 & No comparison of interest \\
\hline Guyton 2000 & No comparison of interest \\
\hline $\begin{array}{l}\text { HDL-Artherosclerosis Treatment Study } \\
2004\end{array}$ & No comparison of interest \\
\hline Hiatt 2010 & No comparison of interest \\
\hline Hoeg 1984 & Follow-up shorter than 6 months \\
\hline Hubacek 2010 & Follow-up shorter than 6 months \\
\hline Illingworth 1994 & No comparison of interest \\
\hline Insull 2004 & Follow-up shorter than 6 months \\
\hline Jungnickel 1997 & Follow-up shorter than 6 months \\
\hline Kane 1990 & No comparison of interest \\
\hline Keenan 1990 & Follow-up shorter than 6 months \\
\hline Klimov 1995 & No comparison of interest \\
\hline Knopp 1985 & No comparison of interest \\
\hline Knopp 1998 & Follow-up shorter than 6 months \\
\hline Lamon-Fava 2008 & Follow-up shorter than 6 months \\
\hline Low 2007 & No outcome of interest \\
\hline Morgan 1998 & Follow-up shorter than 6 months \\
\hline OCEANS 2008 & No comparison of interest \\
\hline
\end{tabular}




\begin{tabular}{|c|c|}
\hline Study & Reason for exclusion \\
\hline Oster 1995 & No comparison of interest \\
\hline Pontiroli 1992 & Follow-up shorter than 6 months \\
\hline Pradhan 2005 & Follow-up shorter than 6 months \\
\hline Sacks 1994 & No comparison of interest \\
\hline Safarova 2011 & No outcome of interest \\
\hline Sakai 2001 & No comparison of interest \\
\hline SEACOAST I $2008 \mathrm{C}$ & No clinical outcome \\
\hline SEACOAST II 2008 & No comparison of interest \\
\hline Shah 2010 & No comparison of interest \\
\hline Smith 1963 & No comparison of interest \\
\hline Sorrentino 2010 & Follow-up shorter than 6 months \\
\hline Sposito 1999 & No comparison of interest \\
\hline Superko 2009 & No comparison of interest \\
\hline Thoenes 2007 & No outcome of interest \\
\hline Tsalamandris 1994 & No comparison of interest \\
\hline Zema 2000 & Follow-up shorter than 6 months \\
\hline
\end{tabular}

Characteristics of ongoing studies [ordered by study ID]

NCT00715273

\begin{tabular}{|c|c|}
\hline Trial name or title & Carotid plaque composition study \\
\hline Methods & Randomised parallel groups, double-blind, follow-up: 5 years \\
\hline Participants & $\begin{array}{l}\text { Inclusion criteria: Aged } 21-70 \text {, clinically established coronary artery disease or carotid artery } \\
\text { disease, family history of cardiovascular disease, apolipoprotein B level } \geq 120 \mathrm{mg} / \mathrm{dL}, \mathrm{LDL} 100 \\
\mathrm{mgdL}-190 \mathrm{mg} / \mathrm{dL} \text { without medication, lipid therapy for no more than } 12 \mathrm{months} \text { before study entry, } \\
\text { medically stable, able to undergo MRI procedure }\end{array}$ \\
\hline
\end{tabular}

Exclusion criteria: immediate plans for carotid endarterectomy, alcohol or drug abuse, liver disease, elevated serum creatine kinase, elevated serum creatinine, diabetes, uncontrolled high BP

Run-in/enrichment: not reported

Interventions

Arm 1: atorvastatin, placebo niacin, and placebo colesevelam. Target for $L D L: \leq 80 \mathrm{mg} / \mathrm{dL}$

Arm 2: atorvastatin, niacin, and placebo colesevelam. Target for LDL: $\leq 80 \mathrm{mg} / \mathrm{dL}$

Arm 3: atorvastatin, niacin, and colesevelam. Target for LDL-C: $\leq 60 \mathrm{mg} / \mathrm{dL}$ 
NCT00715273 (Continued)

Measure to prevent flushing/unblinding due to flushing: not reported

Outcomes $\quad$ Primary outcome: carotid plaque composition, as assessed by MRI

Secondary outcomes: composite of cardiovascular disease death, non-fatal heart attack, stroke, and worsening ischaemia requiring medical interventions

\begin{tabular}{ll}
\hline Starting date & June 2001 \\
\hline Contact information & See NCT00715273 \\
\hline Notes & NCT00715273 \\
\hline
\end{tabular}

\section{NCT02109614}

\section{Trial name or title}

Methods

Early aortic valve lipoprotein(a) lowering trial (EAVaLL)

Randomised parallel groups, double-blind, pilot trial, follow-up: 2 years
Participants
Inclusion criteria: aged $>50$ and $<85$ years, aortic sclerosis, elevated lipoprotein A

Exclusion criteria: current use or documented indication for niacin therapy, niacin intolerance, bicuspid valve, unicuspid valve or other congenital cardiac anomaly, renal disease, comorbidity limiting life expectancy to $<2$ years, liver disease, newly diagnosed or poorly controlled diabetes, gout or use of anti-hyperuricaemic medications

Run-in/enrichment: low-dose niacin $(500 \mathrm{mg} / \mathrm{d})$ for 6 weeks to randomisation to assess tolerability and compliance to the intervention. The niacin dose will be increased by $500 \mathrm{mg}$ increments weekly, as tolerated, to a maximum of $1500 \mathrm{mg} /$ day

Arm 1: extended-release niacin $1500 \mathrm{mg} /$ day-2000 mg/day

Arm 2: placebo

Measure to prevent flushing/unblinding due to flushing: extended-release

\begin{tabular}{ll}
\hline Outcomes & Primary outcome: calcium score by cardiac CT \\
& $\begin{array}{l}\text { Secondary outcome: lipoprotein A, disease progression by echocardiography, peak velocity, mean } \\
\text { gradient, aortic valve area, drug compliance, side effects and adverse events }\end{array}$ \\
\hline Starting date & May 2014 \\
\hline Contact information & See NCT02109614 \\
\hline Notes & NCT02109614 \\
\hline
\end{tabular}

\section{NCT02258074}

\begin{tabular}{ll}
\hline Trial name or title & The CKD optimal management with blnders and nicotinamide (COMBINE) study \\
\hline Methods & Randomised parallel groups, double-blind, pilot study \\
\hline Participants & Inclusion criteria: eGFR between 20 and $45 \mathrm{~mL} / \mathrm{min} / 1.73 \mathrm{~m}^{2}$, aged $18-85$ years, serum phosphate $\geq$ \\
& $2.8 \mathrm{mg} / \mathrm{dL}$, platelet count $\geq 125,000 / \mathrm{mm}^{3}$ \\
\hline
\end{tabular}


NCT02258074 (Continued)

Exclusion criteria: intolerance to study drugs, liver disease, elevated creatine kinase, major haemorrhagic event within the past 6 months, blood transfusion within the past 6 months, secondary hyperparathyroidism, malabsorption, anaemia, decreased serum albumin, dialysis or kidney transplantation, immunosuppressive medications, abuse of alcohol or drugs, vitamin D, phosphate binder, niacin/nicotinamide $>100 \mathrm{mg} /$ day, malignancy

Run-in/enrichment: not reported
Arm 1: lanthanum carbonate $3000 \mathrm{mg} /$ day + nicotinamide $1500 \mathrm{mg} /$ day

Arm 2: lanthanum carbonate $3000 \mathrm{mg} /$ day + nicotinamide placebo

Arm 3: lanthanum carbonate placebo and nicotinamide $1500 \mathrm{mg} /$ day

Arm 4: lanthanum carbonate placebo and nicotinamide placebo

Measure to prevent flushing/unblinding due to flushing: not reported

\section{Outcomes}

Primary outcome: feasibility, serum phosphate, FGF23

Secondary outcomes: cardiovascular disease, left ventricular mass index, left ventricular end diastolic volume, and left atrial volume, intra-renal oxygenation and fibrosis, brain natriuretic peptide, troponin T, cholesterol, asymmetric dimethylarginine, parathyroid hormone, calcitriol, klotho, $\mathrm{N}$ terminal propeptide of type 1 procollagen, tartrate-resistant acid phosphatase, glomerular filtration, albuminuria, $C$ reactive protein, interleukin 6

\begin{tabular}{ll}
\hline Starting date & March 2015 \\
\hline Contact information & See NCT02258074 \\
\hline Notes & NCT02258074 \\
\hline
\end{tabular}

\section{NCT02416739}

\begin{tabular}{ll}
\hline Trial name or title & Anticancer activity of nicotinamide on lung cancer \\
\hline Methods & Randomised, parallel, double-blind, 2 years' follow-up
\end{tabular}

Participants

Inclusion criteria: Aged 19-80 years, non-small-cell lung carcinoma, EGFR mutated, life expectation $>3$ months, $>1$ measurable lesion by RECIST 1.1 which were not exposed to radiation previously, Eastern Cooperative Oncology Group performance status grade $0 \sim 2$

Exclusion criteria: metastasised brain lesion needing operation or radiation, above grade $2 \mathrm{Com}$ mon Toxicity Criteria for Adverse Effects criteria for blood, liver and kidney, no contraception, allergy to nicotinamide

Run-in/enrichment: not reported

Interventions

Arm 1: nicotinamide $1000 \mathrm{mg} /$ day + gefitinib $250 \mathrm{mg} /$ day or erlotinib $150 \mathrm{mg} /$ day

Arm 2: placebo + gefitinib $250 \mathrm{mg} /$ day or erlotinib $150 \mathrm{mg} /$ day

Measure to prevent flushing/unblinding due to flushing: not reported

Outcomes Primary: progression-free survival

Secondary: response rate, quality of life, overall survival

Starting date March 2015

Niacin for primary and secondary prevention of cardiovascular events (Review) 
NCT02416739 (Continued)

Contact information

Notes NCT02416739

\section{NCT02558595}

\begin{tabular}{ll}
\hline Trial name or title & NIAC-PKD2 \\
\hline Methods & Randomised, parallel, double-blind, pilot study, 12 months' follow-up \\
\hline Participants & $\begin{array}{l}\text { Inclusion criteria: aged } 18-60 \text { years, confirmed diagnosis of autosomal dominant polycystic kid- } \\
\text { ney disease, EGFR }>50 \mathrm{~mL} / \mathrm{min} / 1.73 \mathrm{~m}^{2}\end{array}$ \\
& $\begin{array}{l}\text { Exclusion criteria: liver disease, alcohol intake, malabsorption, thrombocytopenia, hypophos- } \\
\text { phataemia, pregnancy or lactation, anti-epileptic drugs, tolvaptan, not able to undergo MRI }\end{array}$ \\
\hline Run-in/enrichment: not reported \\
\hline Interventions & Arm 1: niacinamide $30 \mathrm{mg} / \mathrm{kg} / \mathrm{day}$ \\
\hline Outcomes & Arm 2: placebo \\
\hline Starting date & Secondary: kidney volume, pain, MCP-1, EGFR \\
\hline Contact information & September 2015 \\
\hline See NCT02558595
\end{tabular}

BP: blood pressure

$\mathrm{CT}$ : computed tomography

EGFR: estimated glomerular filtration rate

MRI: magnetic resonance imaging

RECIST: response evaluation criteria in solid tumours

DATA AND ANALYSES

Comparison 1. Niacin versus control, maximum follow-up, available case analysis

\begin{tabular}{lllll}
\hline Outcome or subgroup title & No. of studies & $\begin{array}{l}\text { No. of partici- } \\
\text { pants }\end{array}$ & Statistical method & Effect size \\
\hline 1 Overall mortality & 12 & 35543 & Risk Ratio (M-H, Random, 95\% Cl) & $1.05[0.97,1.12]$ \\
\hline $\begin{array}{l}\text { 2 Overall mortality, sensitivity } \\
\begin{array}{l}\text { analysis with stratification by } \\
\text { risk of bias trials only }\end{array}\end{array}$ & 12 & 35543 & Risk Ratio (M-H, Random, 95\% Cl) & $1.05[0.97,1.12]$ \\
\hline 2.1 High risk of bias & 10 & 6703 & Risk Ratio (M-H, Random, 95\% Cl) & $0.97[0.87,1.09]$ \\
\hline
\end{tabular}




\begin{tabular}{|c|c|c|c|c|}
\hline Outcome or subgroup title & No. of studies & $\begin{array}{l}\text { No. of partici- } \\
\text { pants }\end{array}$ & Statistical method & Effect size \\
\hline 2.2 Low risk of bias & 2 & 28840 & Risk Ratio (M-H, Random, 95\% Cl) & $1.10[1.00,1.20]$ \\
\hline 3 Fatal myocardial infarction & 6 & 33336 & Risk Ratio (M-H, Random, 95\% Cl) & $1.01[0.91,1.11]$ \\
\hline 4 Cardiovascular mortality & 5 & 32966 & Risk Ratio (M-H, Random, 95\% Cl) & $1.02[0.93,1.12]$ \\
\hline $\begin{array}{l}5 \text { Non-cardiovascular mortali- } \\
\text { ty }\end{array}$ & 5 & 32966 & Risk Ratio (M-H, Random, 95\% Cl) & $1.12[0.98,1.28]$ \\
\hline $\begin{array}{l}6 \text { Non-fatal myocardial infarc- } \\
\text { tion }\end{array}$ & 4 & 33164 & Risk Ratio (M-H, Random, 95\% Cl) & $0.91[0.77,1.07]$ \\
\hline $\begin{array}{l}7 \text { Fatal or non-fatal myocardial } \\
\text { infarction }\end{array}$ & 9 & 34829 & Risk Ratio (M-H, Random, 95\% Cl) & $0.93[0.87,1.00]$ \\
\hline 8 Fatal and non-fatal stroke & 7 & 33661 & Risk Ratio (M-H, Random, 95\% Cl) & $0.95[0.74,1.22]$ \\
\hline $\begin{array}{l}9 \text { Revascularisation proce- } \\
\text { dures }\end{array}$ & 8 & 33130 & Risk Ratio (M-H, Random, 95\% Cl) & $0.85[0.68,1.06]$ \\
\hline 10 Flushing & 15 & 11038 & Risk Ratio (M-H, Random, 95\% Cl) & $7.69[4.14,14.28]$ \\
\hline 11 Pruritus & 6 & 5800 & Risk Ratio (M-H, Random, 95\% Cl) & $5.26[2.68,10.32]$ \\
\hline 12 Rash & 9 & 31485 & Risk Ratio (M-H, Random, 95\% Cl) & $3.15[1.94,5.13]$ \\
\hline 13 Headache & 3 & 300 & Risk Ratio (M-H, Random, 95\% Cl) & $1.40[0.86,2.28]$ \\
\hline 14 Gastrointestinal symptoms & 12 & 35353 & Risk Ratio (M-H, Random, 95\% Cl) & $1.69[1.37,2.07]$ \\
\hline $\begin{array}{l}15 \text { Discontinuation of treat- } \\
\text { ment due to side effects }\end{array}$ & 17 & 33539 & Risk Ratio (M-H, Random, 95\% Cl) & $2.17[1.70,2.77]$ \\
\hline 16 New onset diabetes) & 3 & 27982 & Risk Ratio (M-H, Random, 95\% Cl) & $1.32[1.16,1.51]$ \\
\hline
\end{tabular}

Analysis 1.1. Comparison 1 Niacin versus control, maximum follow-up, available case analysis, Outcome 1 Overall mortality.

\begin{tabular}{|c|c|c|c|c|c|}
\hline Study or subgroup & $\begin{array}{c}\text { Niacin } \\
\mathrm{n} / \mathrm{N}\end{array}$ & $\begin{array}{c}\text { Control } \\
n / N\end{array}$ & $\begin{array}{c}\text { Risk Ratio } \\
\text { M-H, Random, } 95 \% \mathrm{Cl}\end{array}$ & Weight & $\begin{array}{c}\text { Risk Ratio } \\
\text { M-H, Random, } 95 \% \text { Cl }\end{array}$ \\
\hline MacLean 2011 & $0 / 298$ & $1 / 277$ & & $0.05 \%$ & $0.31[0.01,7.58]$ \\
\hline Hunninghake 2003 & $0 / 57$ & $1 / 61$ & & $0.05 \%$ & $0.36[0.01,8.57]$ \\
\hline NIA Plaque 2013 & $0 / 59$ & $1 / 58$ & & $0.05 \%$ & $0.33[0.01,7.88]$ \\
\hline Sang 2009 & $0 / 52$ & $1 / 56$ & & $0.05 \%$ & $0.36[0.01,8.61]$ \\
\hline Goldberg 2000 & $0 / 46$ & $1 / 34$ & & $0.05 \%$ & $0.25[0.01,5.91]$ \\
\hline ARBITER-2 2004 & $1 / 78$ & $2 / 71$ & & $0.09 \%$ & $0.46[0.04,4.91]$ \\
\hline PAST 1995 & $3 / 30$ & $4 / 34$ & & $0.26 \%$ & $0.85[0.21,3.5]$ \\
\hline Schoch 1968 & $31 / 140$ & $54 / 283$ & 1 & $3.35 \%$ & $1.16[0.78,1.72]$ \\
\hline AIM-HIGH 2011 & $96 / 1693$ & $82 / 1672$ & $\longrightarrow$ & $6.27 \%$ & $1.16[0.87,1.54]$ \\
\hline
\end{tabular}




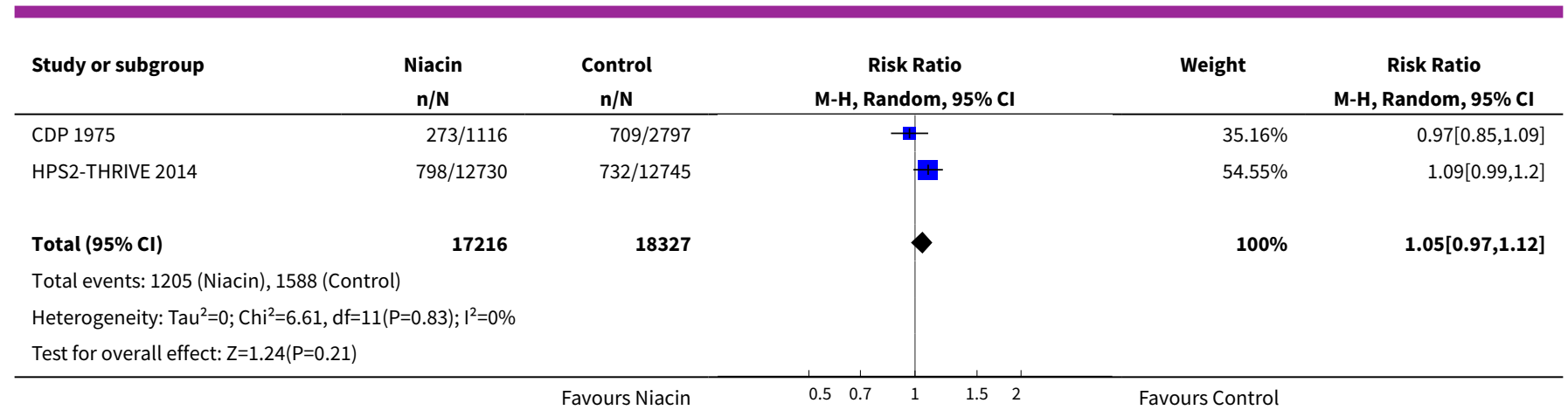

Analysis 1.2. Comparison 1 Niacin versus control, maximum follow-up, available case analysis,
Outcome 2 Overall mortality, sensitivity analysis with stratification by risk of bias trials only.

\begin{tabular}{|c|c|c|c|c|c|}
\hline Study or subgroup & $\begin{array}{c}\text { Niacin } \\
\mathrm{n} / \mathrm{N}\end{array}$ & $\begin{array}{c}\text { Control } \\
\mathrm{n} / \mathrm{N}\end{array}$ & $\begin{array}{c}\text { Risk Ratio } \\
\text { M-H, Random, } 95 \% \text { Cl }\end{array}$ & Weight & $\begin{array}{c}\text { Risk Ratio } \\
\text { M-H, Random, } 95 \% \text { CI }\end{array}$ \\
\hline \multicolumn{6}{|c|}{ 1.2.1 High risk of bias } \\
\hline MacLean 2011 & $0 / 298$ & $1 / 277$ & & $0.05 \%$ & $0.31[0.01,7.58]$ \\
\hline Hunninghake 2003 & $0 / 57$ & $1 / 61$ & & $0.05 \%$ & $0.36[0.01,8.57]$ \\
\hline NIA Plaque 2013 & $0 / 59$ & $1 / 58$ & & $0.05 \%$ & $0.33[0.01,7.88]$ \\
\hline Sang 2009 & $0 / 52$ & $1 / 56$ & & $0.05 \%$ & $0.36[0.01,8.61]$ \\
\hline Maccubbin 2008 & $3 / 917$ & $0 / 239$ & & $0.06 \%$ & $1.83[0.09,35.31]$ \\
\hline ARBITER-2 2004 & $1 / 78$ & $2 / 71$ & & $0.09 \%$ & $0.46[0.04,4.91]$ \\
\hline PAST 1995 & $3 / 30$ & $4 / 34$ & & $0.26 \%$ & $0.85[0.21,3.5]$ \\
\hline Schoch 1968 & $31 / 140$ & $54 / 283$ & & $3.35 \%$ & $1.16[0.78,1.72]$ \\
\hline CDP 1975 & $273 / 1116$ & $709 / 2797$ & & $35.16 \%$ & $0.97[0.85,1.09]$ \\
\hline Subtotal $(95 \% \mathrm{Cl})$ & 2793 & 3910 & & $39.18 \%$ & $0.97[0.87,1.09]$ \\
\hline \multicolumn{6}{|c|}{ Heterogeneity: $\operatorname{Tau}^{2}=0 ; \mathrm{Chi}^{2}=3.82, \mathrm{df}=9(\mathrm{P}=0.92) ; \mathrm{I}^{2}=0 \%$} \\
\hline \multicolumn{6}{|c|}{ Test for overall effect: $Z=0.49(P=0.62)$} \\
\hline \multicolumn{6}{|c|}{ 1.2.2 Low risk of bias } \\
\hline AIM-HIGH 2011 & $96 / 1693$ & $82 / 1672$ & $t$ & $6.27 \%$ & $1.16[0.87,1.54]$ \\
\hline HPS2-THRIVE 2014 & $798 / 12730$ & $732 / 12745$ & 1 & $54.55 \%$ & $1.09[0.99,1.2]$ \\
\hline Subtotal $(95 \% \mathrm{Cl})$ & 14423 & 14417 & & $60.82 \%$ & $1.1[1,1.2]$ \\
\hline \multicolumn{6}{|c|}{ Total events: 894 (Niacin), 814 (Control) } \\
\hline \multicolumn{6}{|c|}{ Heterogeneity: $\operatorname{Tau}^{2}=0 ; \mathrm{Chi}^{2}=0.14, \mathrm{df}=1(\mathrm{P}=0.71) ; \mathrm{I}^{2}=0 \%$} \\
\hline \multicolumn{6}{|c|}{ Test for overall effect: $Z=1.99(P=0.05)$} \\
\hline Total $(95 \% \mathrm{Cl})$ & 17216 & 18327 & & $100 \%$ & $1.05[0.97,1.12]$ \\
\hline \multicolumn{6}{|c|}{ Total events: 1205 (Niacin), 1588 (Control) } \\
\hline Test for subgroup dif & $d f=1(P=0.1), I^{2}$ & & & & \\
\hline
\end{tabular}


Analysis 1.3. Comparison 1 Niacin versus control, maximum followup, available case analysis, Outcome 3 Fatal myocardial infarction.

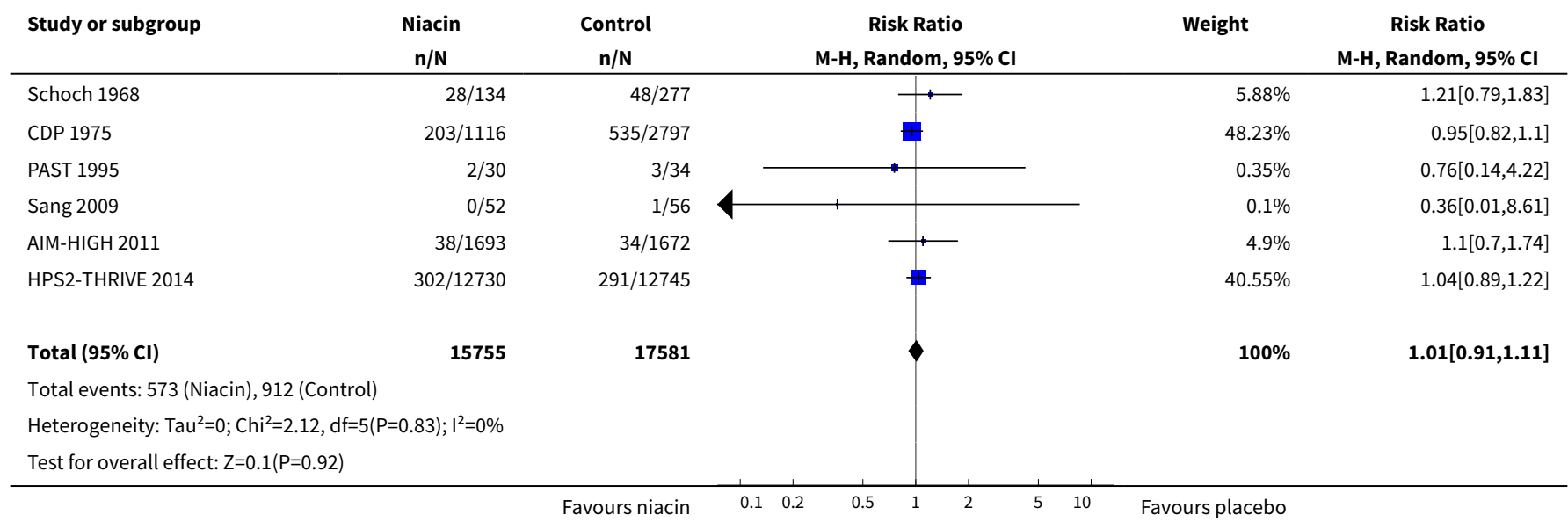

Analysis 1.4. Comparison 1 Niacin versus control, maximum followup, available case analysis, Outcome 4 Cardiovascular mortality.

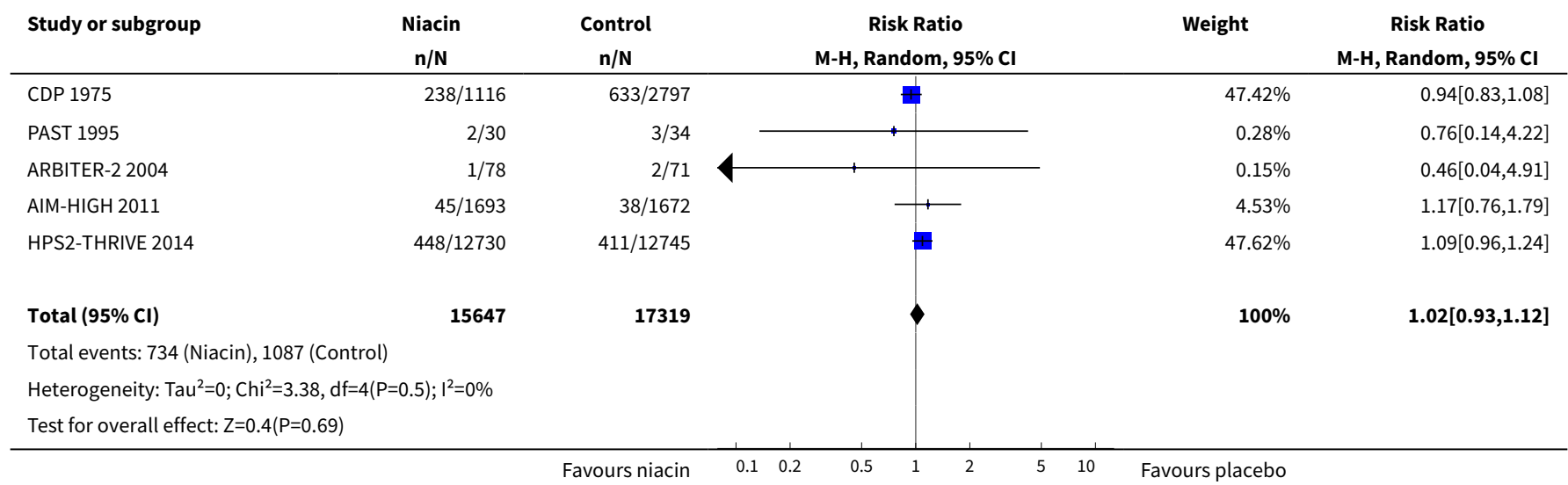

Analysis 1.5. Comparison 1 Niacin versus control, maximum followup, available case analysis, Outcome 5 Non-cardiovascular mortality.

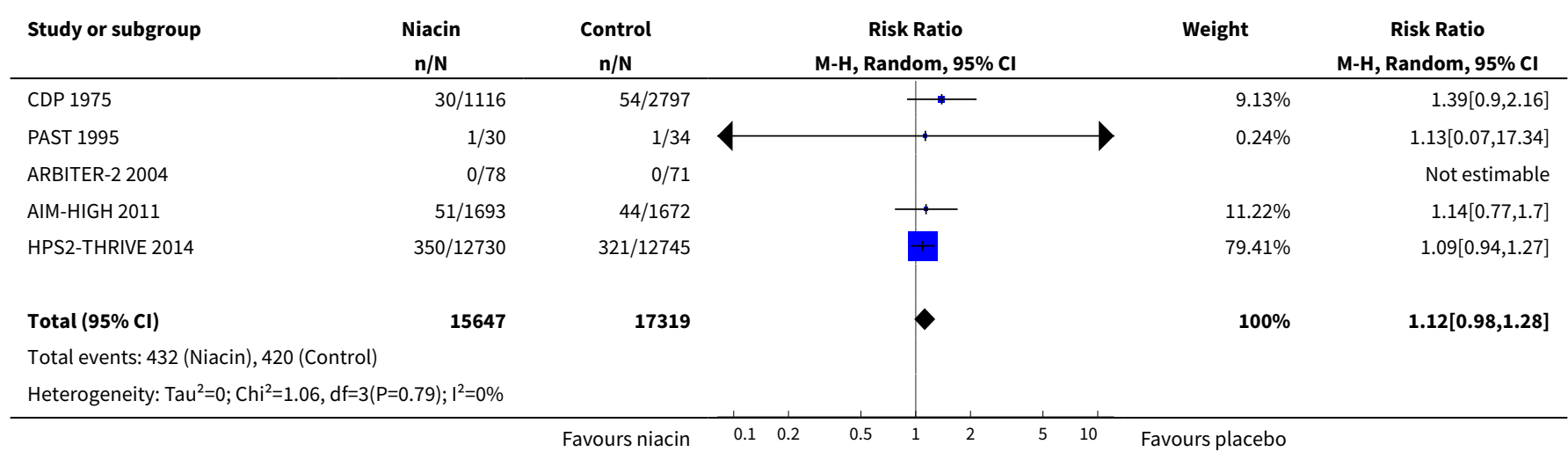




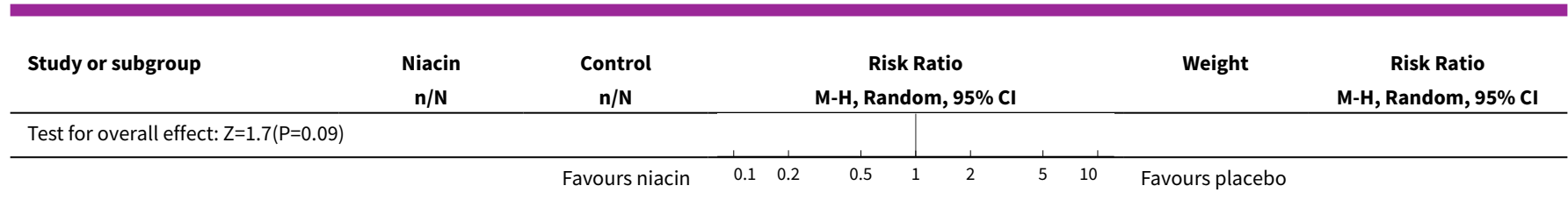

Analysis 1.6. Comparison 1 Niacin versus control, maximum followup, available case analysis, Outcome 6 Non-fatal myocardial infarction.

\begin{tabular}{|c|c|c|c|c|c|}
\hline Study or subgroup & $\begin{array}{c}\text { Niacin } \\
\mathbf{n} / \mathbf{N}\end{array}$ & $\begin{array}{c}\text { Control } \\
n / N\end{array}$ & $\begin{array}{c}\text { Risk Ratio } \\
\text { M-H, Random, } 95 \% \mathrm{Cl}\end{array}$ & Weight & $\begin{array}{c}\text { Risk Ratio } \\
\text { M-H, Random, } 95 \% \text { CI }\end{array}$ \\
\hline Schoch 1968 & $21 / 134$ & $45 / 277$ & $\longrightarrow$ & $10.04 \%$ & $0.96[0.6,1.55]$ \\
\hline CDP 1975 & $114 / 1116$ & $386 / 2797$ & $\rightarrow$ & $29.84 \%$ & $0.74[0.61,0.9]$ \\
\hline AIM-HIGH 2011 & $104 / 1693$ & $93 / 1672$ & $\rightarrow-$ & $21.82 \%$ & $1.1[0.84,1.45]$ \\
\hline HPS2-THRIVE 2014 & $402 / 12730$ & $431 / 12745$ & 畐 & $38.3 \%$ & $0.93[0.82,1.07]$ \\
\hline Total $(95 \% \mathrm{Cl})$ & 15673 & 17491 & & $100 \%$ & $0.91[0.77,1.07]$ \\
\hline \multicolumn{6}{|c|}{ Total events: 641 (Niacin), 955 (Control) } \\
\hline \multicolumn{6}{|c|}{ Heterogeneity: $\operatorname{Tau}^{2}=0.01 ; \mathrm{Chi}^{2}=6.34, \mathrm{df}=3(\mathrm{P}=0.1) ; \mathrm{I}^{2}=52.67 \%$} \\
\hline \multicolumn{6}{|c|}{ Test for overall effect: $Z=1.14(P=0.25)$} \\
\hline
\end{tabular}

Analysis 1.7. Comparison 1 Niacin versus control, maximum follow-up, available case analysis, Outcome 7 Fatal or non-fatal myocardial infarction.

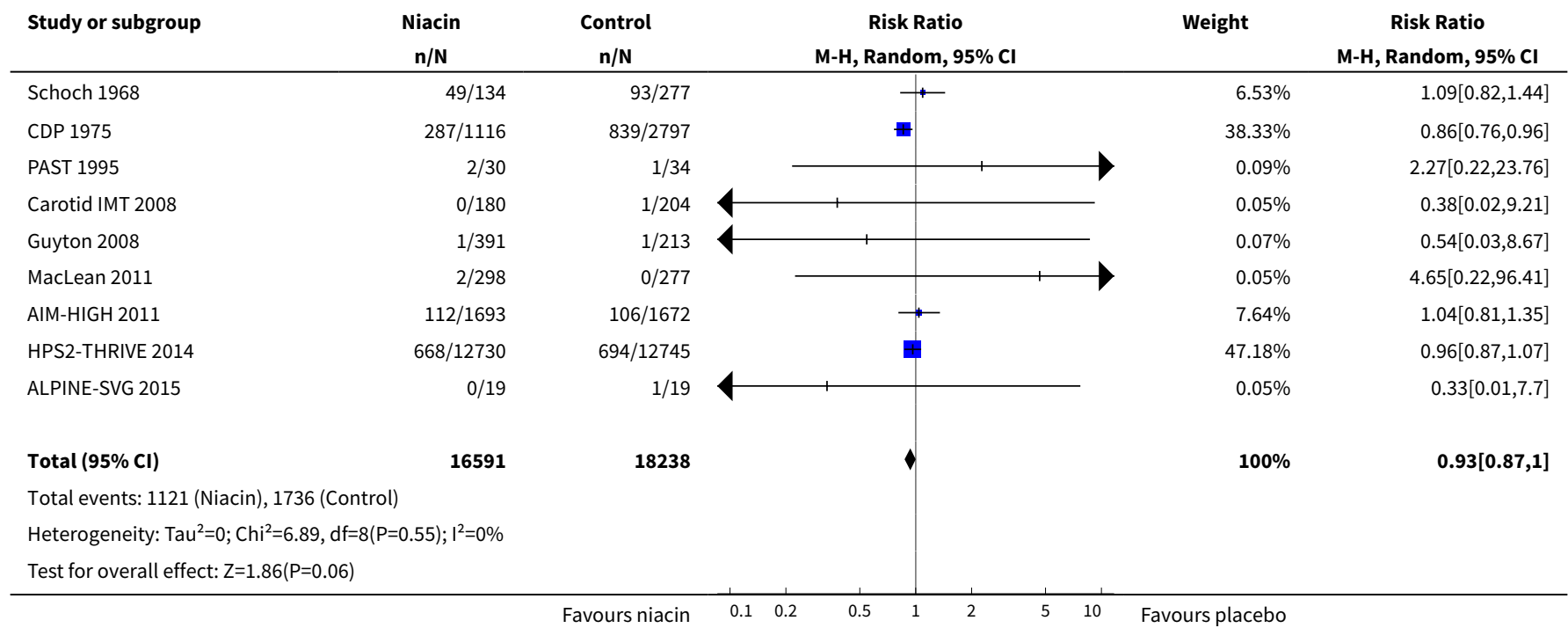


Analysis 1.8. Comparison 1 Niacin versus control, maximum followup, available case analysis, Outcome 8 Fatal and non-fatal stroke.

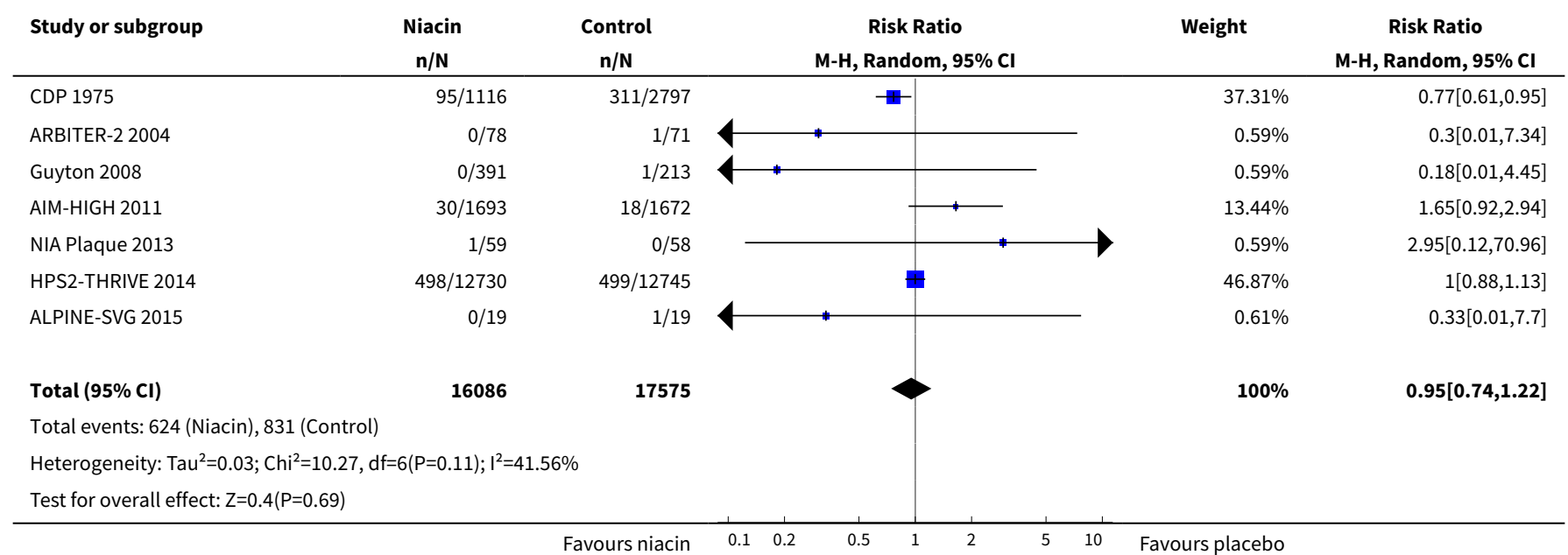

Analysis 1.9. Comparison 1 Niacin versus control, maximum followup, available case analysis, Outcome 9 Revascularisation procedures.

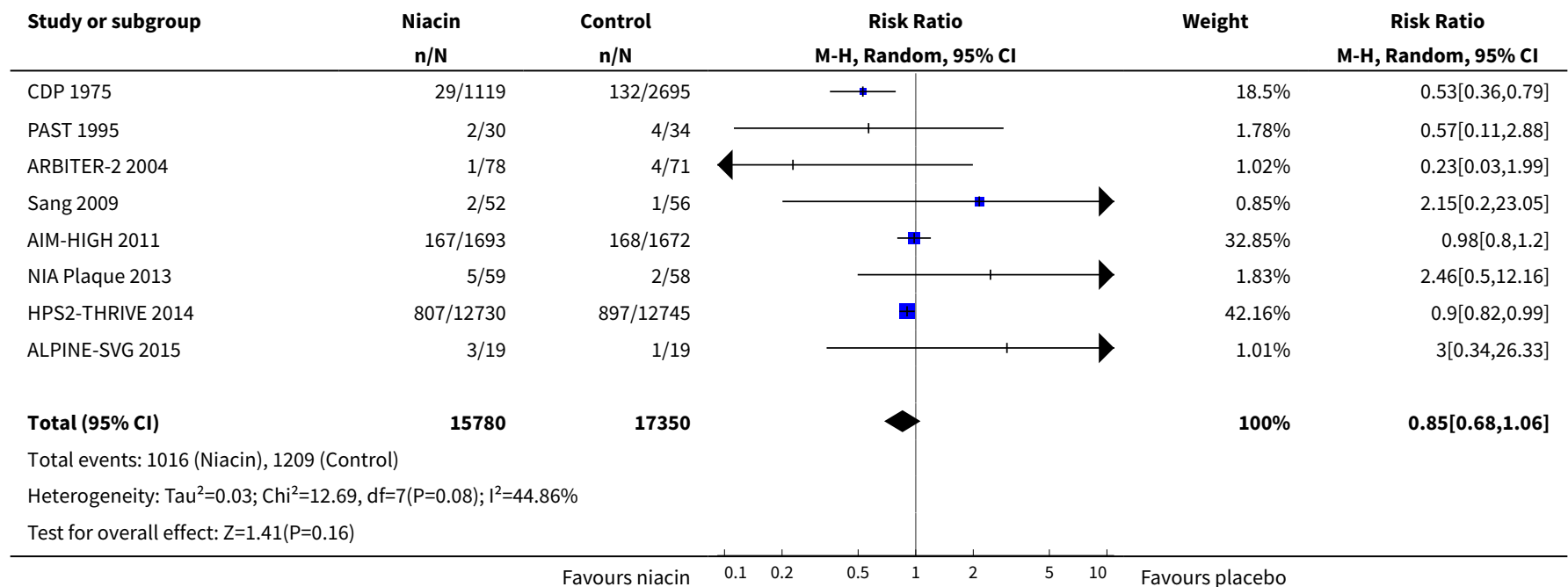

Analysis 1.10. Comparison 1 Niacin versus control, maximum follow-up, available case analysis, Outcome 10 Flushing.

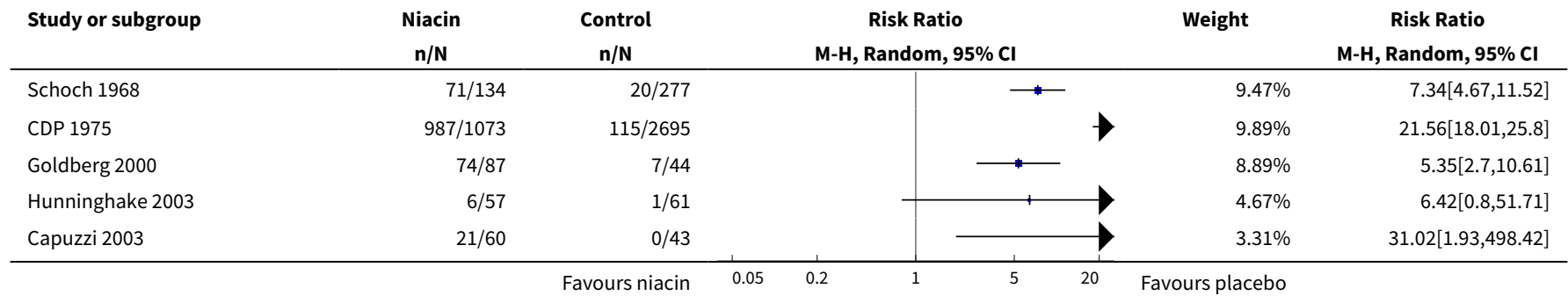




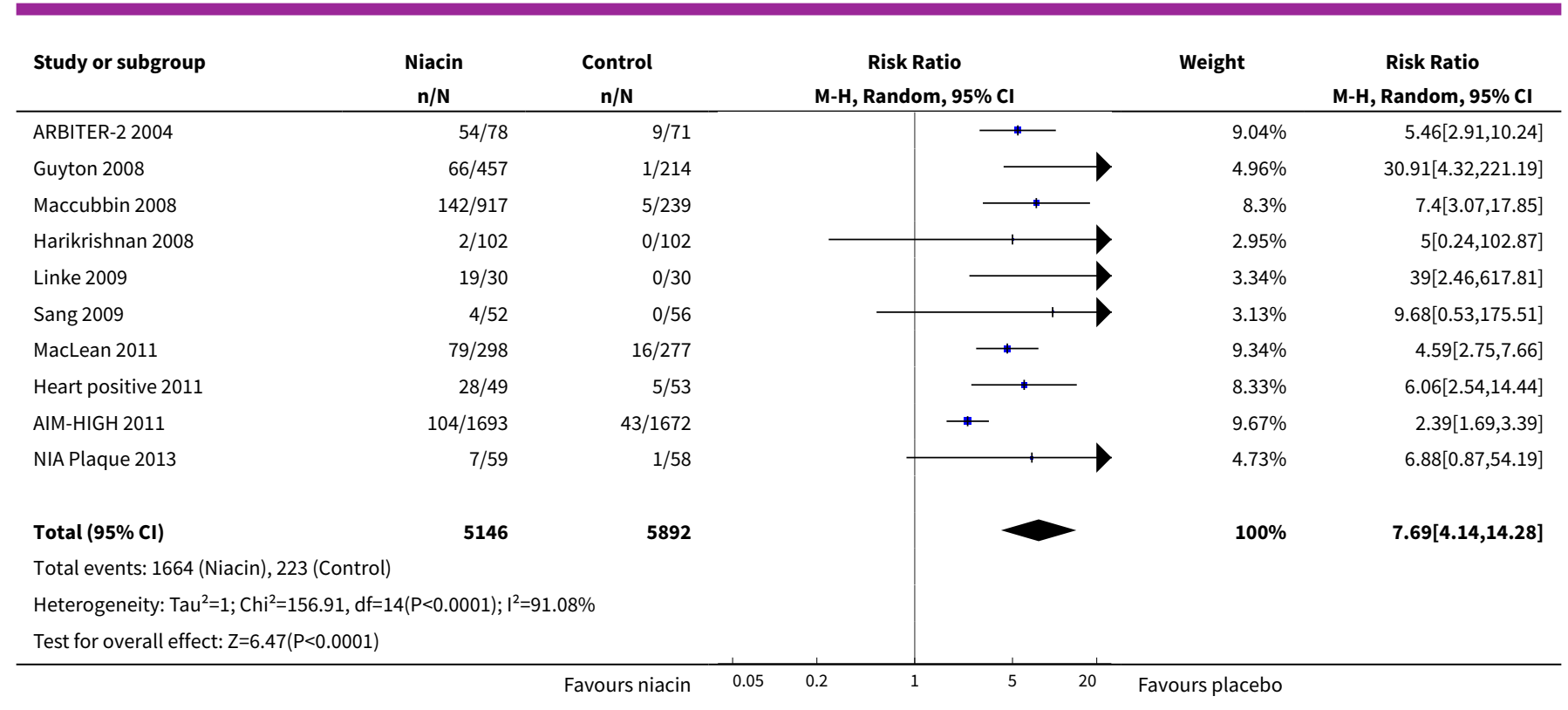

Analysis 1.11. Comparison 1 Niacin versus control, maximum follow-up, available case analysis, Outcome 11 Pruritus.

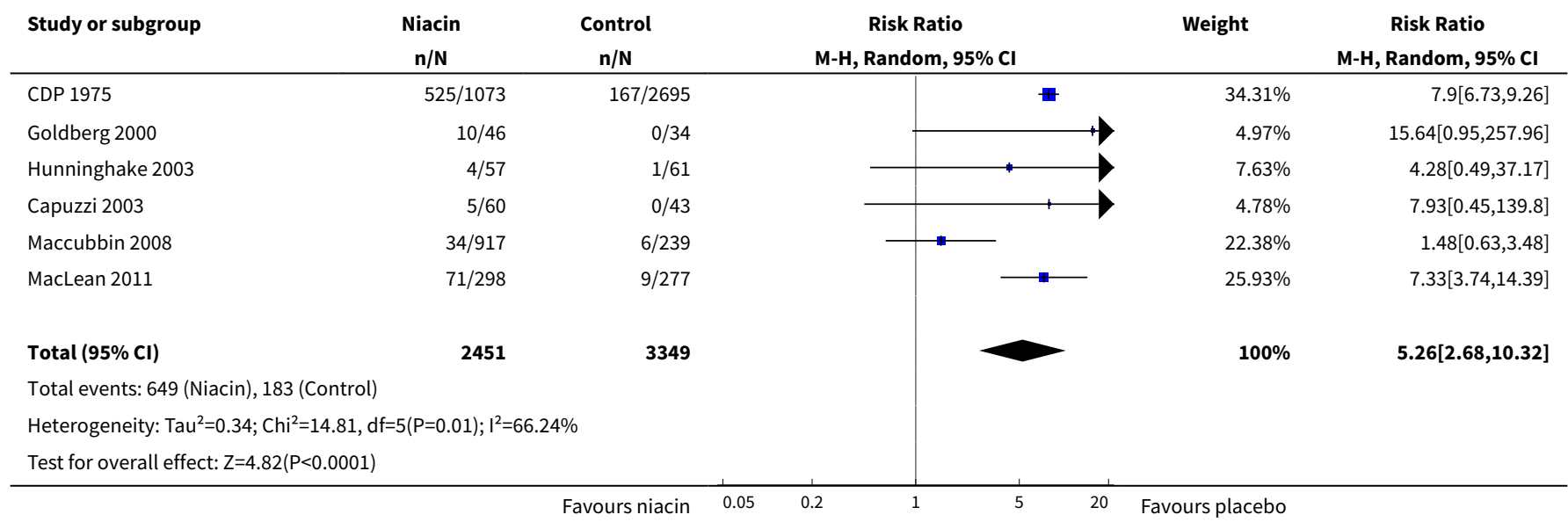

Analysis 1.12. Comparison 1 Niacin versus control, maximum follow-up, available case analysis, Outcome 12 Rash.

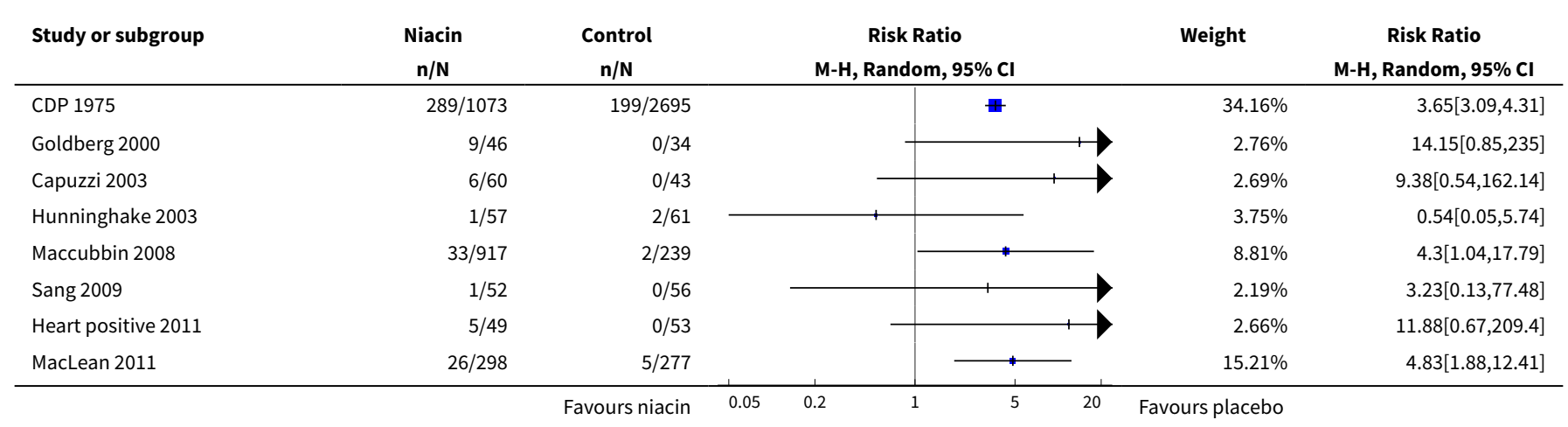




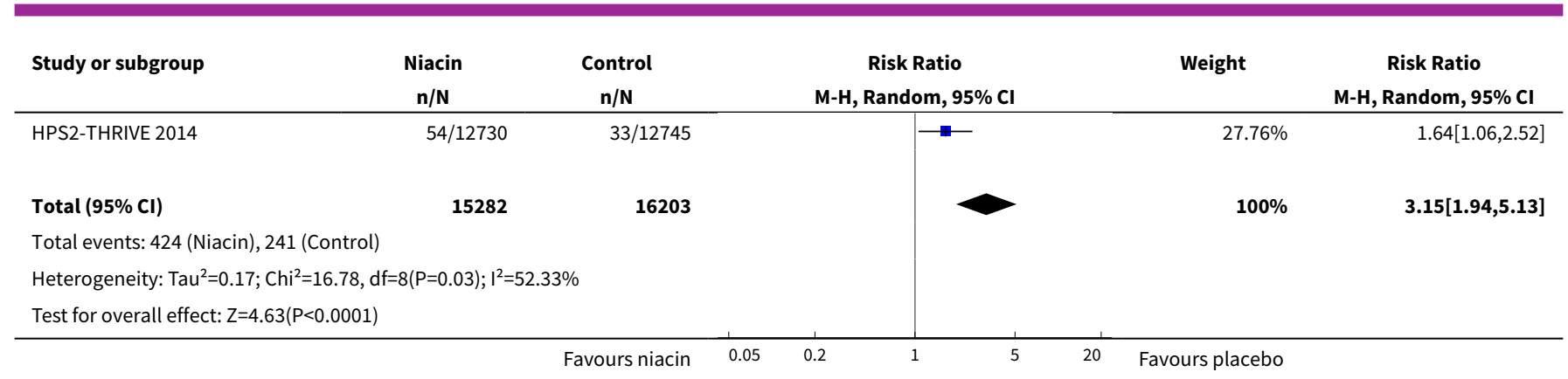

Analysis 1.13. Comparison 1 Niacin versus control, maximum follow-up, available case analysis, Outcome 13 Headache.

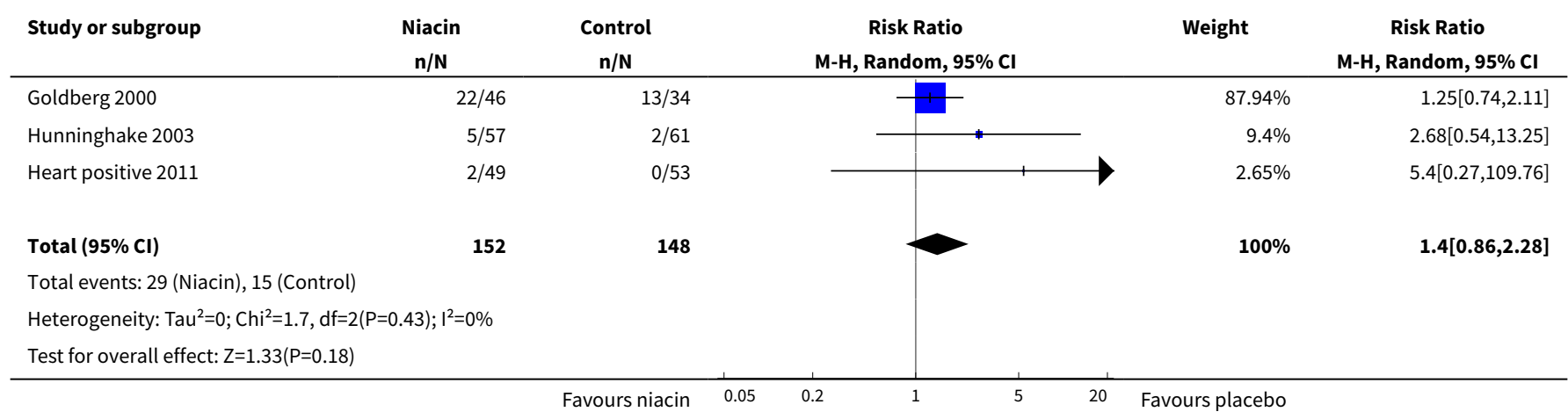

Analysis 1.14. Comparison 1 Niacin versus control, maximum followup, available case analysis, Outcome 14 Gastrointestinal symptoms.

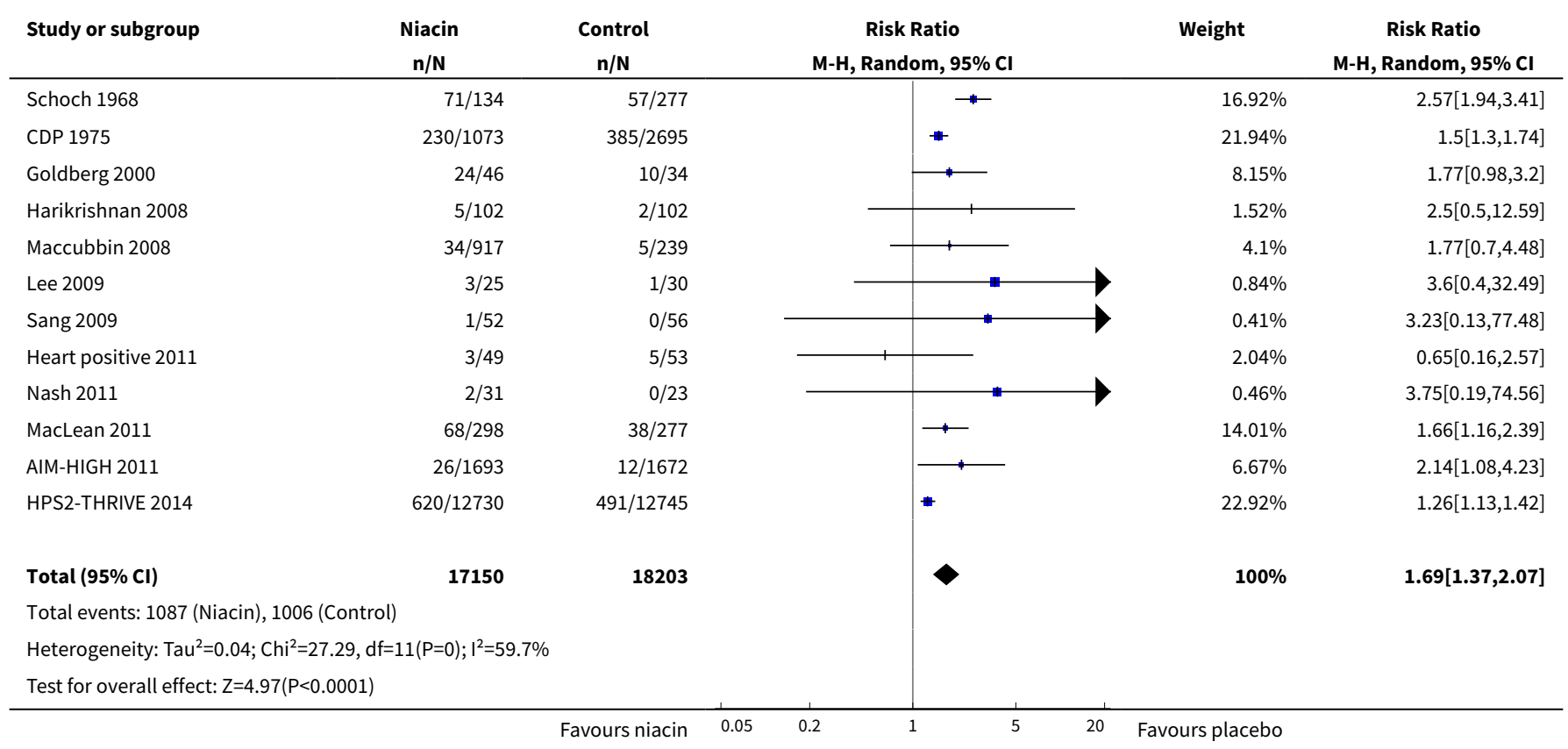


Analysis 1.15. Comparison 1 Niacin versus control, maximum follow-up, available case analysis, Outcome 15 Discontinuation of treatment due to side effects.

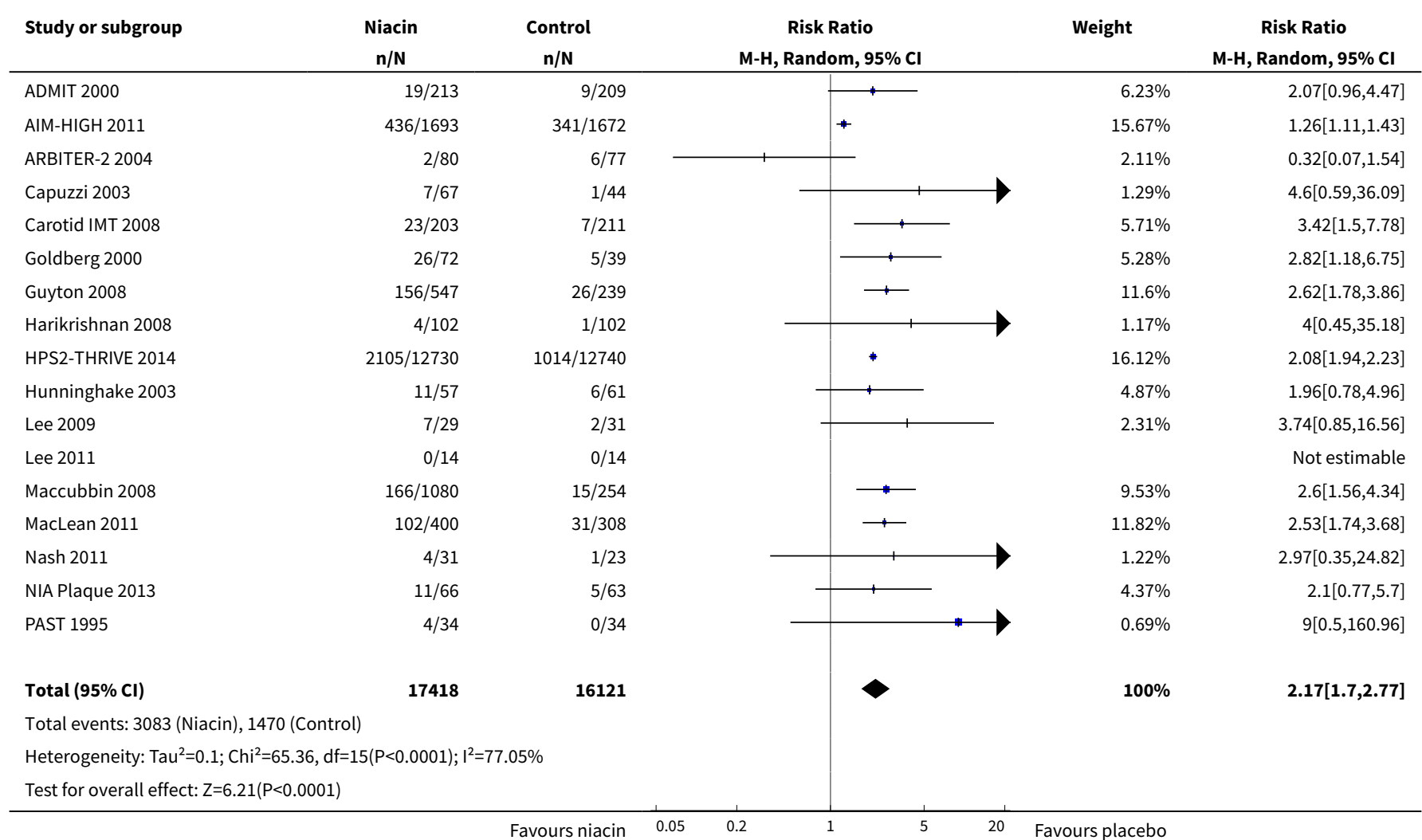

Analysis 1.16. Comparison 1 Niacin versus control, maximum followup, available case analysis, Outcome $16 \mathrm{New}$ onset diabetes).

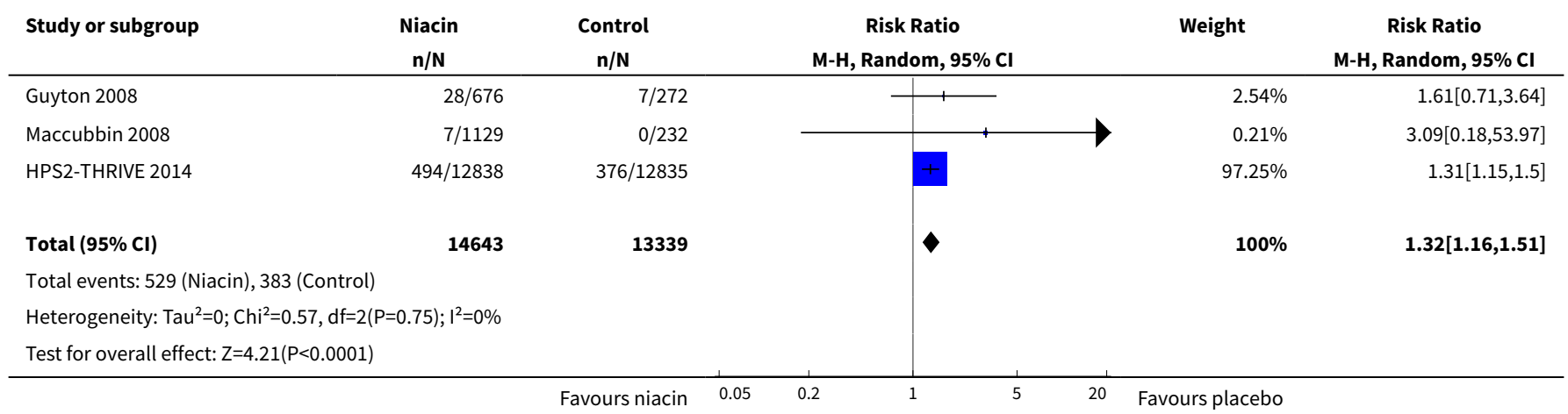




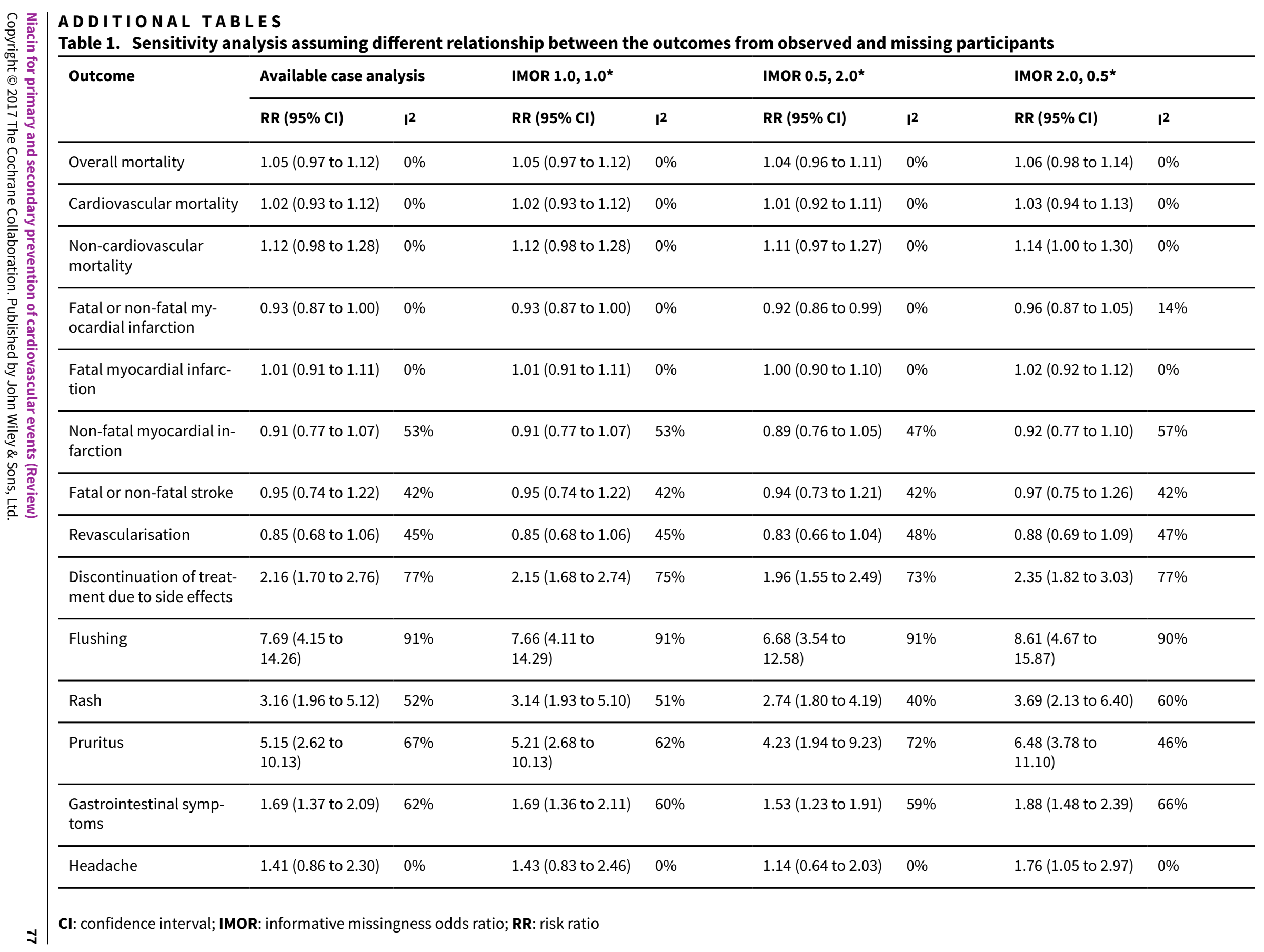


Sensitivity analysis for random-effects meta-analysis assuming different relationship between the outcomes from observed and missing participants and accounting for the uncertainty introduced by the proportion of missing data and assumed relationship (informative missingness odds ratio, IMOR = odds of event in missing data/odds of event in observed data, SD $(\log \mid \mathrm{MOR})=0.5)$. We used the "metamiss"-command in Stata (version 13) (stata.com).

"The two numbers represent the assumed IMORs for the niacin and the control arm, respectively: 1.0, 1.0: missing at random; 0.5, 2.0: assumption favours niacin, 2.0, 0.5:

assumption favours control.

We could not conduct sensitivity analysis for the outcome 'new onset diabetes' because the proportion of missing data was not reported. 
Table 2. Lipid data

\begin{tabular}{|c|c|c|c|c|c|c|}
\hline Study & $\begin{array}{l}\text { Niacin } \\
\text { dose g/day }\end{array}$ & $\begin{array}{l}\text { Follow-up } \\
\text { in months }\end{array}$ & $\begin{array}{l}\text { Total choles- } \\
\text { terol }\end{array}$ & LDL-cholesterol & $\begin{array}{l}\text { HDL-choles- } \\
\text { terol }\end{array}$ & Triglycerides \\
\hline & & & \multicolumn{4}{|c|}{$\begin{array}{l}\text { Baseline mean, } \\
\text { (treatment effect: difference between niacin and control group in mean } \\
\text { change from baseline) in } \mathrm{mg} / \mathrm{dL}\end{array}$} \\
\hline ADMIT 2000 & 3 & 11 & $214(-4)$ & $138(-6)$ & $41(+11)$ & $176(-34)$ \\
\hline AIM-HIGH 2011 & 2 & 38 & $N A(N A)$ & $74(-3)$ & $35(+10)$ & $165(-21)$ \\
\hline ALPINE-SVG 2015 & 2 & 12 & $136(+1)$ & $69(+2)$ & $38(+3)$ & $158(-19)$ \\
\hline ARBITER-2 2004 & 1 & 12 & $158(+6)$ & $89(+3)$ & $40(+8)$ & $163(-12)$ \\
\hline Capuzzi 2003 & 2 & 6 & $262(+3)$ & $146(+6)$ & $36(+6)$ & $377(-6)$ \\
\hline Carotid IMT 2008 & 2 & 18 & $237(-6)$ & $154(-9)$ & $42(+6)$ & $201(-16)$ \\
\hline CDP 1975 & 3 & 72 & $249(-20)$ & NA (NA) & NA (NA) & NA (NA) \\
\hline Goldberg 2000 & 3 & 6 & $300(-31)$ & $216(-48)$ & $45(+8)$ & 191 (NA) \\
\hline Guyton 2008 & 2 & 6 & $241(-4)$ & $156(-9)$ & $51(+11)$ & $159(-30)$ \\
\hline Harikrishnan 2008 & 1.5 & 9 & $178(-9)$ & $112(-11)$ & $35(+5)$ & $157(-5)$ \\
\hline Heart positive 2011 & 2 & 6 & $211(-7)$ & NA (NA) & $39(+5)$ & $306(-25)$ \\
\hline HPS2-THRIVE 2014 & 2 & 23 & $128(-5)$ & $63(-10)$ & $43(+6)$ & $124(-33)$ \\
\hline Hunninghake 2003 & 2 & 6 & $N A(N A)$ & $188(-10)$ & $44(+24)$ & $197(-23)$ \\
\hline Lee 2009 & 2 & 12 & $157(+1)$ & $85(-15)$ & $38(+22)$ & $180(-7)$ \\
\hline Lee 2011 & 1 & 9 & $198(N A)$ & 122 (NA) & 49 (NA) & 160 (NA) \\
\hline Linke 2009 & 1 & 6 & $218(+4)$ & $133(-9)$ & $33(+5)$ & $154(-29)$ \\
\hline Maccubbin 2008 & 2 & 6 & $192(-9)$ & $223(-20)$ & $52(+22)$ & $122(-57)$ \\
\hline MacLean 2011 & 2 & 8 & $127(\mathrm{NA})$ & $164(-33)$ & $86(+21)$ & $50(-15)$ \\
\hline Nash 2011 & 2 & 12 & $178(-15)$ & $118(-22)$ & $33(+8)$ & $141(-21)$ \\
\hline NIA Plaque 2013 & 1.5 & 18 & $172(0)$ & $90(-4)$ & $60(+8)$ & $130(-26)$ \\
\hline PAST 1995 & 0.5 & 36 & $243(-8)$ & $169(-13)$ & $42(+1)$ & $162(-25)$ \\
\hline Sang 2009 & 1 & 12 & $183(\mathrm{NA})$ & 105 (NA) & 50 (NA) & 147 (NA) \\
\hline Schoch 1968 & 4 & 38 & $242(-34)$ & NA (NA) & NA (NA) & NA (NA) \\
\hline
\end{tabular}

NA: not available 


\begin{tabular}{|c|c|c|c|c|c|c|c|c|c|}
\hline \multirow[t]{2}{*}{ Study } & \multirow[t]{2}{*}{ Outcome } & \multicolumn{4}{|c|}{ Niacin group } & \multicolumn{4}{|c|}{ Control group } \\
\hline & & $\begin{array}{l}\text { Ran- } \\
\text { domised }\end{array}$ & Complete & Missing & Events & $\begin{array}{l}\text { Ran- } \\
\text { domised }\end{array}$ & Complete & Missing & Events \\
\hline $\begin{array}{l}\text { ADMIT } \\
2000\end{array}$ & $\begin{array}{l}\text { Discontinuation of treatment due to side ef- } \\
\text { fects }\end{array}$ & 237 & 213 & 24 & 19 & 231 & 209 & 22 & 9 \\
\hline \multirow{11}{*}{$\begin{array}{l}\text { AIM-HIGH } \\
2011\end{array}$} & Fatal myocardial infarction & 1718 & 1693 & 25 & 38 & 1696 & 1672 & 24 & 34 \\
\hline & Non-cardiovascular mortality & 1718 & 1693 & 25 & 51 & 1696 & 1672 & 24 & 44 \\
\hline & Fatal or non-fatal myocardial infarction & 1718 & 1693 & 25 & 112 & 1696 & 1672 & 24 & 106 \\
\hline & Cardiovascular mortality & 1718 & 1693 & 25 & 45 & 1696 & 1672 & 24 & 38 \\
\hline & Overall mortality & 1718 & 1693 & 25 & 96 & 1696 & 1672 & 24 & 82 \\
\hline & Non-fatal myocardial infarction & 1718 & 1693 & 25 & 104 & 1696 & 1672 & 24 & 93 \\
\hline & Revascularisation procedures & 1718 & 1693 & 25 & 167 & 1696 & 1672 & 24 & 168 \\
\hline & Fatal or non-fatal stroke & 1718 & 1693 & 25 & 30 & 1696 & 1672 & 24 & 18 \\
\hline & Flushing & 1718 & 1693 & 25 & 104 & 1696 & 1672 & 24 & 43 \\
\hline & Gastrointestinal symptoms & 1718 & 1693 & 25 & 26 & 1696 & 1672 & 24 & 12 \\
\hline & $\begin{array}{l}\text { Discontinuation of treatment due to side ef- } \\
\text { fects }\end{array}$ & 1718 & 1693 & 25 & 436 & 1696 & 1672 & 24 & 341 \\
\hline \multirow{6}{*}{$\begin{array}{l}\text { ARBITER-2 } \\
2004\end{array}$} & Flushing & 87 & 78 & 9 & 54 & 80 & 71 & 9 & 9 \\
\hline & Overall mortality & 87 & 78 & 9 & 1 & 80 & 71 & 9 & 2 \\
\hline & Cardiovascular mortality & 87 & 78 & 9 & 1 & 80 & 71 & 9 & 2 \\
\hline & Non-cardiovascular mortality & 87 & 78 & 9 & 0 & 80 & 71 & 9 & 0 \\
\hline & Revascularisation procedures & 87 & 78 & 9 & 1 & 80 & 71 & 9 & 4 \\
\hline & Fatal or non-fatal stroke & 87 & 78 & 9 & 0 & 80 & 71 & 9 & 1 \\
\hline
\end{tabular}




\begin{tabular}{|c|c|c|c|c|c|c|c|c|c|}
\hline & $\begin{array}{l}\text { Discontinuation of treatment due to side ef- } \\
\text { fects }\end{array}$ & 87 & 80 & 7 & 2 & 80 & 77 & 3 & 6 \\
\hline \multirow{3}{*}{$\begin{array}{l}\text { ALPINE- } \\
\text { SVG } 2015\end{array}$} & Fatal or non-fatal myocardial infarction & 19 & 19 & 0 & 0 & 19 & 19 & 0 & 1 \\
\hline & Fatal and non-fatal stroke & 19 & 19 & 0 & 0 & 19 & 19 & 0 & 1 \\
\hline & Revascularisation procedures & 19 & 19 & 0 & 3 & 19 & 19 & 0 & 1 \\
\hline \multirow{4}{*}{$\begin{array}{l}\text { Capuzzi } \\
2003\end{array}$} & Flushing & 72 & 60 & 12 & 21 & 46 & 43 & 3 & 0 \\
\hline & Pruritus & 72 & 60 & 12 & 5 & 46 & 43 & 3 & 0 \\
\hline & Rash & 72 & 60 & 12 & 6 & 46 & 43 & 3 & 0 \\
\hline & $\begin{array}{l}\text { Discontinuation of treatment due to side ef- } \\
\text { fects }\end{array}$ & 72 & 67 & 5 & 7 & 46 & 44 & 2 & 1 \\
\hline \multirow{2}{*}{$\begin{array}{l}\text { Carotid } \\
\text { IMT } 2008\end{array}$} & Fatal or non-fatal myocardial infarction & 214 & 180 & 34 & 0 & 218 & 204 & 14 & 1 \\
\hline & $\begin{array}{l}\text { Discontinuation of treatment due to side ef- } \\
\text { fects }\end{array}$ & 214 & 203 & 11 & 23 & 218 & 211 & 7 & 7 \\
\hline \multirow[t]{10}{*}{ CDP 1975} & Overall mortality & 1119 & 1116 & 3 & 273 & 2798 & 2797 & 1 & 709 \\
\hline & Cardiovascular mortality & 1119 & 1116 & 3 & 238 & 2798 & 2797 & 1 & 633 \\
\hline & Non-cardiovascular mortality & 1119 & 1116 & 3 & 30 & 2798 & 2797 & 1 & 54 \\
\hline & Fatal myocardial infarction & 1119 & 1116 & 3 & 203 & 2798 & 2797 & 1 & 535 \\
\hline & Non-fatal myocardial infarction & 1119 & 1116 & 3 & 114 & 2798 & 2797 & 1 & 386 \\
\hline & Fatal or non-fatal myocardial infarction & 1119 & 1116 & 3 & 287 & 2798 & 2797 & 1 & 839 \\
\hline & Fatal or non-fatal stroke & 1119 & 1116 & 3 & 95 & 2798 & 2797 & 1 & 311 \\
\hline & Revascularisation procedures & 1119 & 1116 & 3 & 29 & 2798 & 2695 & 103 & 132 \\
\hline & Gastrointestinal symptoms & 1119 & 1073 & 46 & 230 & 2798 & 2695 & 103 & 385 \\
\hline & Flushing & 1119 & 1073 & 46 & 987 & 2798 & 2695 & 103 & 115 \\
\hline
\end{tabular}




\begin{tabular}{|c|c|c|c|c|c|c|c|c|c|}
\hline & Pruritus & 1119 & 1073 & 46 & 525 & 2798 & 2695 & 103 & 167 \\
\hline & Rash & 1119 & 1073 & 46 & 289 & 2798 & 2695 & 103 & 199 \\
\hline \multirow{7}{*}{$\begin{array}{l}\text { Goldberg } \\
2000\end{array}$} & Flushing & 87 & 87 & 0 & 74 & 44 & 44 & 0 & 7 \\
\hline & Headache & 87 & 46 & 41 & 22 & 44 & 34 & 10 & 13 \\
\hline & Gastrointestinal symptoms & 87 & 46 & 41 & 24 & 44 & 34 & 10 & 10 \\
\hline & Pruritus & 87 & 46 & 41 & 10 & 44 & 34 & 10 & 0 \\
\hline & Rash & 87 & 46 & 41 & 9 & 44 & 34 & 10 & 0 \\
\hline & Overall mortality & 87 & 46 & 41 & 0 & 44 & 34 & 10 & 1 \\
\hline & $\begin{array}{l}\text { Discontinuation of treatment due to side ef- } \\
\text { fects }\end{array}$ & 87 & 72 & 15 & 26 & 44 & 39 & 5 & 5 \\
\hline \multirow{6}{*}{$\begin{array}{l}\text { Guyton } \\
2008\end{array}$} & Overall mortality & 676 & 391 & 285 & 0 & 272 & 213 & 59 & 0 \\
\hline & Fatal or non-fatal myocardial infarction & 676 & 391 & 285 & 1 & 272 & 213 & 59 & 1 \\
\hline & Fatal or non-fatal stroke & 676 & 391 & 285 & 0 & 272 & 213 & 59 & 1 \\
\hline & Flushing & 676 & 457 & 219 & 66 & 272 & 214 & 58 & 1 \\
\hline & New onset diabetes & 569 & NR & NR & 25 & 229 & NR & NR & 2 \\
\hline & $\begin{array}{l}\text { Discontinuation of treatment due to side ef- } \\
\text { fects }\end{array}$ & 676 & 547 & 129 & 156 & 272 & NR & 33 & 26 \\
\hline \multirow{3}{*}{$\begin{array}{l}\text { Harikrish- } \\
\text { nan } 2008\end{array}$} & Flushing & 104 & 102 & 2 & 2 & 106 & NR & 4 & 0 \\
\hline & Gastrointestinal symptoms & 104 & 102 & 2 & 5 & 106 & 102 & 4 & 2 \\
\hline & $\begin{array}{l}\text { Discontinuation of treatment due to side ef- } \\
\text { fects }\end{array}$ & 104 & 102 & 2 & 4 & 106 & 102 & 4 & 1 \\
\hline \multirow{2}{*}{$\begin{array}{l}\text { Heart pos- } \\
\text { itive } 2011\end{array}$} & Gastrointestinal symptoms & 92 & 49 & 43 & 1 & 88 & 53 & 35 & 2 \\
\hline & Rash & 723 & 412 & 311 & 1 & 315 & 237 & 78 & 2 \\
\hline
\end{tabular}




\begin{tabular}{|c|c|c|c|c|c|c|c|c|c|}
\hline & Headache & 780 & 493 & 287 & 2 & 378 & 315 & 63 & 0 \\
\hline & Flushing & 92 & 49 & 43 & 28 & 88 & 53 & 35 & 5 \\
\hline \multirow{12}{*}{$\begin{array}{l}\text { HPS2- } \\
\text { THRIVE } \\
2014\end{array}$} & Fatal or non-fatal myocardial infarction & 12838 & 12730 & 108 & 668 & 12835 & 12745 & 90 & 694 \\
\hline & Non-fatal myocardial infarction & 12838 & 12730 & 108 & 402 & 12835 & 12745 & 90 & 431 \\
\hline & Non-cardiovascular mortality & 12838 & 12730 & 108 & 350 & 12835 & 12745 & 90 & 321 \\
\hline & Fatal myocardial infarction & 12838 & 12730 & 108 & 302 & 12835 & 12745 & 90 & 291 \\
\hline & Cardiovascular mortality & 12838 & 12730 & 108 & 448 & 12835 & 12745 & 90 & 411 \\
\hline & Fatal or non-fatal stroke & 12838 & 12730 & 108 & 498 & 12835 & 12745 & 90 & 499 \\
\hline & Revascularisation procedures & 12838 & 12730 & 108 & 807 & 12835 & 12745 & 90 & 897 \\
\hline & Overall mortality & 12838 & 12730 & 108 & 798 & 12835 & 12745 & 90 & 732 \\
\hline & New onset diabetes & 8704 & NR & NR & 494 & 8670 & NR & NR & 376 \\
\hline & Gastrointestinal symptoms & 12838 & 12730 & 108 & 620 & 12835 & 12745 & 90 & 491 \\
\hline & Rash & 12838 & 12730 & 108 & 54 & 12835 & 12745 & 90 & 33 \\
\hline & $\begin{array}{l}\text { Discontinuation of treatment due to side ef- } \\
\text { fects }\end{array}$ & 12838 & 12730 & 108 & 2105 & 12835 & 12740 & 95 & 1014 \\
\hline \multirow{6}{*}{$\begin{array}{l}\text { Hunning- } \\
\text { hake } 2003\end{array}$} & Flushing & 57 & 57 & 0 & 6 & 61 & 61 & 0 & 1 \\
\hline & Overall mortality & 57 & 57 & 0 & 0 & 61 & 61 & 0 & 1 \\
\hline & Headache & 57 & 57 & 0 & 5 & 61 & 61 & 0 & 2 \\
\hline & Pruritus & 57 & 57 & 0 & 4 & 61 & 61 & 0 & 1 \\
\hline & rash & 57 & 57 & 0 & 1 & 61 & 61 & 0 & 2 \\
\hline & $\begin{array}{l}\text { Discontinuation of treatment due to side ef- } \\
\text { fects }\end{array}$ & 57 & 57 & 0 & 11 & 61 & 61 & 0 & 6 \\
\hline
\end{tabular}




\begin{tabular}{|c|c|c|c|c|c|c|c|c|c|}
\hline \multirow[t]{2}{*}{ Lee 2009} & Gastrointestinal symptoms & 35 & 25 & 10 & 3 & 36 & 30 & 6 & 1 \\
\hline & $\begin{array}{l}\text { Discontinuation of treatment due to side ef- } \\
\text { fects }\end{array}$ & 35 & 29 & 6 & 7 & 36 & 31 & 5 & 2 \\
\hline Lee 2011 & $\begin{array}{l}\text { Discontinuation of treatment due to side ef- } \\
\text { fects }\end{array}$ & 14 & 14 & 0 & 0 & 14 & 14 & 0 & 0 \\
\hline \multirow[t]{2}{*}{ Linke 2009} & flushing & 30 & 30 & 0 & 19 & 30 & 30 & 0 & 0 \\
\hline & Overall mortality & 30 & 30 & 0 & 0 & 30 & 30 & 0 & 0 \\
\hline \multirow{7}{*}{$\begin{array}{l}\text { Maccub- } \\
\text { bin } 2008\end{array}$} & Rash & 1343 & 917 & 426 & 33 & 270 & 239 & 31 & 2 \\
\hline & $\begin{array}{l}\text { Discontinuation of treatment due to side ef- } \\
\text { fects }\end{array}$ & 1339 & 1080 & 259 & 166 & 270 & 254 & 16 & 15 \\
\hline & Overall mortality & 1343 & 917 & 426 & 3 & 270 & 239 & 31 & 0 \\
\hline & Pruritus & 1343 & 917 & 426 & 34 & 270 & 239 & 31 & 6 \\
\hline & Flushing & 1343 & 917 & 426 & 142 & 270 & 239 & 31 & 5 \\
\hline & Gastrointestinal symptoms & 1343 & 917 & 426 & 34 & 270 & 239 & 31 & 5 \\
\hline & New onset diabetes & 1129 & NR & NR & 7 & 232 & NR & NR & 2 \\
\hline \multirow[t]{7}{*}{$\begin{array}{l}\text { MacLean } \\
2011\end{array}$} & $\begin{array}{l}\text { Discontinuation of treatment due to side ef- } \\
\text { fects }\end{array}$ & 454 & 400 & 54 & 102 & 342 & 308 & 34 & 31 \\
\hline & Overall mortality & 454 & 298 & 156 & 0 & 342 & 277 & 65 & 1 \\
\hline & Fatal or non-fatal myocardial infarction & 454 & 298 & 156 & 2 & 342 & 277 & 65 & 0 \\
\hline & Gastrointestinal symptoms & 454 & 298 & 156 & 68 & 342 & 277 & 65 & 38 \\
\hline & Pruritus & 454 & 298 & 156 & 71 & 342 & 277 & 65 & 9 \\
\hline & Rash & 454 & 298 & 156 & 26 & 342 & 277 & 65 & 5 \\
\hline & Flushing & 454 & 298 & 156 & 79 & 342 & 277 & 65 & 16 \\
\hline
\end{tabular}




\begin{tabular}{|c|c|c|c|c|c|c|c|c|c|}
\hline \multirow[t]{2}{*}{ Nash 2011} & Gastrointestinal symptoms & 31 & 31 & 0 & 2 & 23 & 23 & 0 & 0 \\
\hline & $\begin{array}{l}\text { Discontinuation of treatment due to side ef- } \\
\text { fects }\end{array}$ & 31 & 31 & 0 & 4 & 23 & 23 & 0 & 1 \\
\hline \multirow{5}{*}{$\begin{array}{l}\text { NIA } \\
\text { Plaque } \\
2013\end{array}$} & Revascularisation procedures & 72 & 59 & 13 & 5 & 73 & 58 & 15 & 2 \\
\hline & Fatal or non-fatal stroke & 72 & 59 & 13 & 1 & 73 & 58 & 15 & 0 \\
\hline & Overall mortality & 72 & 59 & 13 & 0 & 73 & 58 & 15 & 1 \\
\hline & Flushing & 72 & 59 & 13 & 7 & 73 & 58 & 15 & 1 \\
\hline & $\begin{array}{l}\text { Discontinuation of treatment due to side ef- } \\
\text { fects }\end{array}$ & 72 & 66 & 6 & 11 & 73 & 63 & 10 & 5 \\
\hline \multirow[t]{7}{*}{ PAST 1995} & Overall mortality & 40 & 30 & 10 & 3 & 45 & 34 & 11 & 4 \\
\hline & Fatal myocardial infarction & 40 & 30 & 10 & 2 & 45 & 34 & 11 & 3 \\
\hline & Cardiovascular mortality & 40 & 30 & 10 & 2 & 45 & 34 & 11 & 3 \\
\hline & Non-cardiovascular mortality & 40 & 30 & 10 & 1 & 45 & 34 & 11 & 1 \\
\hline & Fatal or non-fatal myocardial infarction & 40 & 30 & 10 & 2 & 45 & 34 & 11 & 1 \\
\hline & Revascularisation procedures & 40 & 30 & 10 & 2 & 45 & 34 & 11 & 4 \\
\hline & $\begin{array}{l}\text { Discontinuation of treatment due to side ef- } \\
\text { fects }\end{array}$ & 40 & 34 & 6 & 4 & 45 & 34 & 11 & 0 \\
\hline \multirow[t]{6}{*}{ Sang 2009} & Rash & 52 & 52 & 0 & 1 & 56 & 56 & 0 & 0 \\
\hline & Flushing & 52 & 52 & 0 & 4 & 56 & 56 & 0 & 0 \\
\hline & Gastrointestinal symptoms & 52 & 52 & 0 & 1 & 56 & 56 & 0 & 0 \\
\hline & Revascularisation procedures & 52 & 52 & 0 & 2 & 56 & 56 & 0 & 1 \\
\hline & Overall mortality & 52 & 52 & 0 & 0 & 56 & 56 & 0 & 1 \\
\hline & Fatal myocardial infarction & 52 & 52 & 0 & 0 & 56 & 56 & 0 & 1 \\
\hline
\end{tabular}




\begin{tabular}{|c|c|c|c|c|c|c|c|c|c|}
\hline Schoch & Gastrointestinal symptoms & 141 & 134 & 7 & 71 & 284 & 277 & 7 & 57 \\
\hline & Flushing & 141 & 134 & 7 & 71 & 284 & 277 & 7 & 20 \\
\hline & Overall mortality & 141 & 140 & 1 & 31 & 284 & 283 & 1 & 54 \\
\hline & Fatal myocardial infarction & 141 & 134 & 7 & 28 & 284 & 277 & 7 & 48 \\
\hline & Non-fatal myocardial infarction & 141 & 134 & 7 & 21 & 284 & 277 & 7 & 45 \\
\hline & Fatal or non-fatal myocardial infarction & 141 & 134 & 7 & 49 & 284 & 277 & 7 & 93 \\
\hline
\end{tabular}




\section{APPEN DICES}

\section{Appendix 1. Search strategies}

\section{CENTRAL}

\#1 MeSH descriptor Niacin, this term only

\#2 MeSH descriptor Niacinamide, this term only

\#3 (niacin):ti,ab,kw

\#4 (nicotinic acid):ti,ab,kw

\#5 (nicamin):ti,ab,kw

\#6 nicotinate:ti,ab,kw

\#7 (nico 400):ti,ab,kw

\#8 (nico-400):ti,ab,kw

\#9 (nico400):ti,ab,kw

\#10 induracin:ti,ab,kw

\#11 (nicolar):ti,ab,kw

\#12 (nicocap):ti,ab,kw

\#13 wampocap:ti,ab,kw

\#14 (nicobid):ti,ab,kw

\#15 (3 pyridinecarboxylic acid):ti,ab,kw

\#16 3-pyridinecarboxylic acid:ti,ab,kw

\#17 (enduracin):ti,ab,kw

\#18 (niacinamide):ti,ab,kw

\#19 papulex:ti,ab,kw

\#20 vitamin b3:ti,ab,kw

\#21 (vitamin b 3):ti,ab,kw

\#22 (vitamin pp):ti,ab,kw

\#23 nicotinamide:ti,ab,kw

\#24 enduramide:ti,ab,kw

\#25 (nicobion):ti,ab,kw

\#26 (3 pyridinecarboxamide)

\#27 (3-pyridinecarboxamide):ti,ab,kw

\#28 (nicotinsaureamid):ti,ab,kw

\#29 (Niaspan):ti,ab,kw

\#30 (Tredaptive):ti,ab,kw

\#31 (antipellagra factor):ti,ab,kw 
\#32 (b-3-50*.):ti,ab,kw

\#33 niacor:ti,ab,kw

\#34 (nicotinex):ti,ab,kw

\#35 (vitb3):ti,ab,kw

\#36 nicamid:ti,ab,kw

\#37 (nicomide-t):ti,ab,kw

\#38 nicosedine:ti,ab,kw

\#39 (pellagra* near/2 factor).:ti,ab,kw

\#40 (\#1 OR \#2 OR \#3 OR \#4 OR \#5 OR \#6 OR \#7 OR \#8 OR \#9 OR \#10 OR \#11 OR \#12 OR \#13 OR \#14 OR \#15 OR \#16 OR \#17 OR \#18 OR \#19 OR \#20 OR \#21 OR \#22 OR \#23 OR \#24 OR \#25 OR \#26 OR \#27 OR \#28 OR \#29 OR \#30 OR \#31 OR \#32 OR\#33 OR \#34 OR \#35 OR \#36 OR \#37 OR \#38 OR \#39)

\#41 MeSH descriptor Cardiovascular Diseases explode all trees

\#42 (cardio*):ti,ab,kw

\#43 (cardia*):ti,ab,kw

\#44 (heart*):ti,ab,kw

\#45 (coronary*):ti,ab,kw

\#46 (angina*):ti,ab,kw

\#47 (ventric*):ti,ab,kw

\#48 (myocard $\left.{ }^{\star}\right): \mathrm{ti}, \mathrm{ab}, \mathrm{kw}$

\#49 (pericard*):ti,ab,kw

\#50 (isch?em ${ }^{\star}$ ):ti,ab,kw

\#51 MeSH descriptor Stroke explode all trees

\#52 (stroke or stokes):ti,ab,kw

\#53 (cerebrovasc $\left.{ }^{\star}\right): t i, a b, k w$

\#54 (apoplexy):ti,ab,kw

\#55 (brain near/2 accident*):ti,ab,kw

\#56 ((brain* or cerebral or lacunar) near/2 infarct $\left.{ }^{\star}\right): t i, a b, k w$

\#57 MeSH descriptor Hypertension explode all trees

\#58 (hypertensi ${ }^{\star}$ ):ti,ab,kw

\#59 (peripheral arter $^{\star}$ disease $\left.^{\star}\right): t i, a b, k w$

\#60 ((high or increased or elevated) near/2 blood pressure):ti,ab,kw

\#61 MeSH descriptor Hyperlipidemias explode all trees

\#62 (hyperlipid*):ti,ab,kw

\#63 (hyperlip?emia*):ti,ab,kw

\#64 (hypercholesterol*):ti,ab,kw

\#65 (hypercholester?emia*):ti,ab,kw

Niacin for primary and secondary prevention of cardiovascular events (Review) 
\#66 (hyperlipoprotein?emia*):ti,ab,kw

\#67 (hypertriglycerid?emia*):ti,ab,kw

\#68 (\#41 OR \#42 OR \#43 OR \#44 OR \#45 OR \#46 OR \#47 OR \#48 OR \#49 OR \#50 OR \#51 OR \#52 OR \#53 OR \#54 OR \#55 OR \#56 OR \#57 OR \#58 OR \#59 OR \#60 OR \#61 OR \#62 OR \#63 OR \#64 OR \#65 OR \#66 OR \#67)

\#69 (\#40 AND \#68)

\section{MEDLINE 0 vid}

1 Niacin/

2 Niacinamide/

3 niacin.tw.

4 nicotinic acid.tw.

5 nicamin.tw.

6 nicotinate.tw.

7 nico 400.tw.

8 nico-400.tw.

9 nico400.tw.

10 induracin.tw.

11 nicolar.tw.

12 nicocap.tw.

13 wampocap.tw.

14 nicobid.tw.

153 pyridinecarboxylic acid.tw.

16 3-pyridinecarboxylic acid.tw.

17 enduracin.tw.

18 niacinamide.tw.

19 papulex.tw.

20 vitamin b3.tw.

21 vitamin b 3.tw.

22 vitamin pp.tw.

23 nicotinamide.tw.

24 enduramide.tw.

25 nicobion.tw.

263 pyridinecarboxamide.tw.

27 3-pyridinecarboxamide.tw.

28 nicotinsaureamid.tw.

29 Niaspan.tw. 
30 Tredaptive.tw.

31 antipellagra factor.tw.

32 b- $3-50^{\star} . t w$.

33 niacor.tw.

34 nicotinex.tw.

35 vitb3.tw.

36 nicamid.tw.

37 nicomide-t.tw.

38 nicosedine.tw.

39 (pellagra* adj2 factor).tw.

40 or/1-39

41 exp Cardiovascular Diseases/

42 cardio*.tw.

43 cardia*.tw.

44 heart $^{*}$. tw.

45 coronary ${ }^{\star} . t w$.

46 angina*.tw.

47 ventric ${ }^{\star}$. tw.

48 myocard $^{\star} . t w$.

49 pericard $^{\star}$. tw.

50 isch?em*.tw.

51 exp Stroke/

52 (stroke or stokes).tw.

53 cerebrovasc $^{\star}$.tw.

54 apoplexy.tw.

55 (brain adj2 accident $\left.{ }^{\star}\right)$. tw.

56 ((brain* or cerebral or lacunar) adj2 infarct $\left.{ }^{\star}\right)$. tw.

57 exp Hypertension/

58 hypertensi ${ }^{\star}$. tw.

59 peripheral arter ${ }^{\star}$ disease ${ }^{\star} . t w$.

60 ((high or increased or elevated) adj2 blood pressure).tw.

61 exp Hyperlipidemias/

62 hyperlipid ${ }^{\star}$. tw.

63 hyperlip?emia*.tw.

64 hypercholesterol ${ }^{*}$. tw.

Niacin for primary and secondary prevention of cardiovascular events (Review) 
65 hypercholester?emia*.tw.

66 hyperlipoprotein?emia*.tw.

67 hypertriglycerid?emia*.tw.

68 or/41-67

6940 and 68

70 randomized controlled trial.pt.

71 controlled clinical trial.pt.

72 randomized.ab.

73 placebo.ab.

74 drug therapy.fs.

75 randomly.ab.

76 trial.ab.

77 groups.ab.

7870 or 71 or 72 or 73 or 74 or 75 or 76 or 77

79 exp animals/ not humans.sh.

8078 not 79

8169 and 80

\section{Em base Ovid}

1 Niacin/

2 Niacinamide/

3 niacin.tw.

4 nicotinic acid.tw.

5 nicamin.tw.

6 nicotinate.tw.

7 nico 400.tw.

8 nico-400.tw.

9 nico400.tw.

10 induracin.tw.

11 nicolar.tw.

12 nicocap.tw.

13 wampocap.tw.

14 nicobid.tw.

153 pyridinecarboxylic acid.tw.

16 3-pyridinecarboxylic acid.tw.

17 enduracin.tw.

Niacin for primary and secondary prevention of cardiovascular events (Review) 
18 niacinamide.tw.

19 papulex.tw.

20 vitamin b3.tw.

21 vitamin b 3.tw.

22 vitamin pp.tw.

23 nicotinamide.tw.

24 enduramide.tw.

25 nicobion.tw.

263 pyridinecarboxamide.tw.

27 3-pyridinecarboxamide.tw.

28 nicotinsaureamid.tw.

29 Niaspan.tw.

30 Tredaptive.tw.

31 antipellagra factor.tw.

32 b-3-50*.tw.

33 niacor.tw.

34 nicotinex.tw.

35 vitb3.tw.

36 nicamid.tw.

37 nicomide-t.tw.

38 nicosedine.tw.

39 (pellagra* adj2 factor).tw.

40 or/1-39

41 exp Cardiovascular Diseases/

42 cardio $^{\star}$. tw.

43 cardia*.tw.

44 heart $^{\star}$. tw.

45 coronary ${ }^{\star} . t w$.

46 angina*.tw.

47 ventric*.tw.

48 myocard $^{\star}$. tw.

49 pericard ${ }^{\star}$. tw.

50 isch?em ${ }^{\star} . t w$.

51 exp Stroke/

52 (stroke or stokes).tw.

Niacin for primary and secondary prevention of cardiovascular events (Review) 
53 cerebrovasc ${ }^{\star}$. tw.

54 apoplexy.tw.

55 (brain adj2 accident $\left.{ }^{\star}\right)$.tw.

56 ((brain* or cerebral or lacunar) adj2 infarct*).tw.

57 exp Hypertension/

58 hypertensi $^{\star}$.tw.

59 peripheral arter* disease*.tw.

60 ((high or increased or elevated) adj2 blood pressure).tw.

61 exp Hyperlipidemias/

62 hyperlipid*.tw.

63 hyperlip?emia*.tw.

64 hypercholesterol $^{\star}$. tw.

65 hypercholester?emia*.tw. (

66 hyperlipoprotein?emia*.tw.

67 hypertriglycerid?emia*.tw.

68 or/41-67

6940 and 68

70 random\$.tw.

71 factorial\$.tw.

72 crossover\$.tw.

73 cross over\$.tw.

74 cross-over\$.tw.

75 placebo\$.tw.

76 (doubl\$ adj blind\$).tw.

77 (singl\$ adj blind\$).tw.

78 assign\$.tw.

79 allocat\$.tw.

80 volunteer\$.tw.

81 crossover procedure/

82 double blind procedure/

83 randomized controlled trial/

84 single blind procedure/

8570 or 71 or 72 or 73 or 74 or 75 or 76 or 77 or 78 or 79 or 80 or 81 or 82 or 83 or 84

86 (animal/ or nonhuman/) not human/

8785 not 86

Niacin for primary and secondary prevention of cardiovascular events (Review) 
8869 and 87

\section{ISI Web of Science}

\#14 \#13 AND \#12

\#13 TS=((random* or blind $^{\star}$ or allocat ${ }^{\star}$ or assign* ${ }^{\star}$ or trial ${ }^{\star}$ or placebo* or crossover ${ }^{\star}$ or cross-over $\left.\left.^{\star}\right)\right)$

\#12 \#11 AND \#7

\#11 \#10 OR \#9 OR \#8

\#10 TS=(hypertensi ${ }^{\star}$ or peripheral arter* disease* or ((high or increased or elevated) near/2 ("blood pressure")) or hyperlipid or hyperlip? emia $^{\star}$ or hypercholesterol ${ }^{\star}$ or hypercholester?emia* or hyperlipoprotein?emia* or hypertriglycerid?emia*)

\#9 TS=((stroke or stokes) or cerebrovasc ${ }^{\star}$ or apoplexy or (brain near/2 accident $\left.{ }^{\star}\right)$ or ((brain* or cerebral or lacunar) near/2 infarct $\left.\left.{ }^{\star}\right)\right)$

\#8 TS=(cardio* or cardia* or heart* or coronary* or angina* or ventric* or myocard* or pericard* or isch?em)

\#7 \#6 OR \#5 OR \#4 OR \#3 OR \#2 OR \#1

\#6 TS=(antipellagra factor or b-3-50* or niacor or nicotinex or vitb3 or nicamid or nicomide-t or nicosedine or (pellagra* near/2 factor))

\#5 TS=(nicobion or 3 pyridinecarboxamide or 3-pyridinecarboxamide or nicotinsaureamid or Niaspan or Tredaptive)

\#4 TS=(vitamin b3 or vitamin b 3 or vitamin pp or nicotinamide or enduramide)

\#3 TS=(3 pyridinecarboxylic acid or 3-pyridinecarboxylic acid or enduracin or niacinamide or papulex)

\#2 TS=(induracin or nicolar or nicocap or wampocap or nicobid)

\#1 TS=(niacin or nicotinic acid or nicamin or nicotinate or nico 400 or nico-400 or nico400)

\section{CONTRIBUTIONSOF AUTHORS}

SS screened titles and abstracts, retrieved potentially eligible full texts, assessed full texts for eligibility, screened reference lists and trials registries, extracted relevant data, assessed risk of bias, conducted the statistical analyses, contributed to interpretation of the results and writing of the final review. SS is the guarantor.

MB conceived the review, wrote the protocol, contributed to data extraction, risk of bias assessment, the statistical analysis, the interpretation of results and writing of the final review.

RS wrote the protocol, contributed to screening of titles and abstracts, retrieval of potentially eligible full texts, assessment of full texts for eligibility, data extraction, risk of bias assessment and critical revision of the final review.

KKO contributed to screening of titles and abstracts, retrieval of potentially eligible full texts, assessment of full texts for eligibility, data extraction, risk of bias assessment and critical revision of the final review.

AA contributed to retrieval of potentially eligible full texts, data extraction, risk of bias assessment and critical revision of the final review.

LH contributed to assessment of full texts for eligibility, data extraction, reviewed the manuscript and approved the final version.

AJN conceived the review, wrote the protocol, screened titles and abstracts, assessed full texts for eligibility, extracted relevant data, assessed risk of bias, contributed to the interpretation of results and writing of the final review.

\section{DECLARATIONS OF INTEREST}

SS: none known

MB: none known

RS: none known

KKO: none known

AA: none known

LH: none known

AJN: none known 


\section{SOURCESOF SUPPORT}

\section{Internal sources}

- No sources of support., Other.

\section{External sources}

- Ciber de Epidemiologia y Salud Publica (CIBERESP), Spanish Ministry of Science, Spain.

- This project was supported by the National Institute for Health Research, via Cochrane Infrastructure funding to the Heart Group. The views and opinions expressed therein are those of the authors and do not necessarily reflect those of the Systematic Reviews Programme, NIHR, NHS or the Department of Health, UK.

\section{DIFFERENCES BETWEEN PROTOCOLANDREVIEW}

We did not search the database CINAHL which is of little relevance for cardiovascular trials.

We did not conduct the pre-specified meta-regression analyses for participant age and gender, since mean age and proportion of men did not vary substantially across trials. We did not conduct the pre-specified meta-regression analysis for items about trial quality. Instead, we stratified the primary analysis by trials with low, unclear, or high risk of bias and considered the trials at low risk of bias in a sensitivity analysis.

We planned to calculate the percentage of change in lipid levels for each trial as the difference in the mean change from baseline to end of follow-up. Instead we have presented the data in Table 2 in $\mathrm{mg} / \mathrm{dL}$.

Since niacin did not effectively improve any of our pre-specified clinical outcomes (seriously limiting the variability of the dependent variable) and because our group had already conducted a large meta-regression analysis including any lipid-modifying agents and diets that showed a strong association of change of LDL-cholesterol with clinical outcomes but no independent association of change of HDLcholesterol with clinical outcomes (Briel 2009), we refrained from conducting the pre-specified meta-regression analysis of niacin trials investigating the association between clinical outcomes and change in HDL-cholesterol.

We did not contact experts in the field and authors of included studies about incomplete data, ongoing and unpublished studies.

We refined our strategy to conduct sensitivity analysis. Instead of stratifying treatment effects by individual items of the risk of bias instrument, we stratified the primary meta-analysis by trials with low, unclear, and high risk of bias. Instead of stratifying by trials using niacin on top of other lipid-modifying drugs versus trials using niacin monotherapy, we conducted a meta-regression analysis investigating the association between outcome and percentage of participants receiving background statin therapy.

We changed our strategy to handle missing data from assuming that no clinical events occurred for participants with missing outcomes data. Instead, we considered available case analysis as our primary analysis and conducted sensitivity analyses using three different assumptions about the relationship between missing and observed outcome data.

We could not assess the risk of reporting bias by comparing protocols to publications because the available protocols were either published retrospectively or did not specify any outcome relevant for the present systematic review.

Given the results, we did not calculate numbers needed to treat per year to prevent one event.

We added the outcome new onset diabetes motivated by the meta-analysis Goldie 2015, which found a significantly increased risk for new onset diabetes.

We used the GRADE approach to assess the quality of evidence and included a 'Summary of findings' table.

\section{NDEX TERMS}

\section{Medical Subject Headings (MeSH)}

*Primary Prevention; *Secondary Prevention; Cardiovascular Diseases [mortality] [ ${ }^{*}$ prevention \& control]; Myocardial Infarction [mortality] [prevention \& control]; Niacin [*administration \& dosage] [adverse effects]; Randomized Controlled Trials as Topic [statistics \& numerical data]; Stroke [mortality] [prevention \& control]; Vasodilator Agents [*administration \& dosage] [adverse effects]

\section{MeSH check words}

Adult; Aged; Humans; Middle Aged 